\title{
INTRODUGTION
}

The most interesting man at Gray's was Fottrell, the man whose memoirs ought to be interesting, for he had acted as intermediary between the Castle (that is, Hamilton) and Parnell at the time when secret communications were passing between them, although openly they were at war. ${ }^{1}$

It has been observed that generations of historians 'have been chained to the task of explaining why Gladstone chose in 1885 to champion Irish claims'.2 Chief amongst these claims was that for national selfdetermination, an issue that was to determine the course of AngloIrish relations for the next forty years. It was, as one contemporary politician observed, 'the pivot on which the political future turned'. ${ }^{3}$ This volume re-examines why, late in 1885 , the leader of the Liberal Party embraced the idea of Irish home rule without securing the support of his party for this radical departure. In his recent biography of Gladstone, Richard Shannon admits that his subject's conviction that Irish home rule had become a matter of absolute urgency by midDecember 1885 'has always been something of a puzzle', and he claims that 'there is nothing in the records' to indicate that Irish nationalism then threatened any 'critical degree of violent action' against the British government of Ireland. ${ }^{4}$ This book therefore examines the advice and information that Gladstone received about Ireland at this critical time. It casts light on communications and transactions that are only partly known in order to provide a fuller chronology of the first home rule episode, and so to help solve this puzzle.

The idea that Gladstone's promotion of Irish home rule was an act of magnanimity that sprang from his sense of fair play was first articulated by the liberal historians John Morley and J.L. Hammond. More recent study, which has drawn attention to Gladstone's reading of histories that emphasized the injustices of

' Stephen Gwynn and Gertrude M. Tuckwell, The Life of the Rt. Hon. Sir Charles W. Dilke, 2 vols (London, I917), II, p. I40.

2 Alan O'Day, History Sixth (March I990).

${ }^{3}$ A. Hawkins and J. Powell (eds), The Journal of John Wodehouse, First Earl of Kimberley for I862-1902 (London, I997), p. 35.

${ }^{4}$ Richard Shannon, Gladstone: heroic minister, I865-I898 (London, 200o), pp. 394-395. 
British rule in Ireland, lends support to this interpretation. ${ }^{5}$ Historians less enamoured by Gladstone have argued that political opportunism played a large part in his adoption of home rule. His conversion to this policy has been minutely examined within the particular contexts of Westminster politics and the internal dynamics of the Liberal Party, the conclusion being that home rule was the means by which Gladstone sought to maintain his ascendancy over a fractious following and actually had little to do with Ireland. The Irish policies pursued by successive British ministries, it is asserted, 'cannot be explained in terms of Irish circumstance' but should be understood solely 'in terms of parliamentary combinations'. ${ }^{6}$ Even scholars sympathetic to Gladstone have pointed out that, during his first administration of I868-I874, he regarded Ireland as 'a preoccupation, not an interest, an embarrassment, not an intellectual attraction', his Irish policy aiming simply 'to draw a line between the Fenians \& the people of Ireland, \& to make the people of Ireland indisposed to cross it'.

The view that decisions about Irish home rule were taken in isolation from events occurring in Ireland has been challenged and should be further considered in the light of the documentary evidence contained in this volume. ${ }^{8} \mathrm{It}$ is now recognized that Irish contingencies and the relative balance of forces in Irish politics crucially influenced calculations made by British politicians and civil servants. ${ }^{9}$ For this reason, the machinery of the responsible departments of government and the role played by civil servants merit closer attention. One authority on the home rule question has admitted an 'inability to trace the way in which cabinet discussion was embodied in the work of government departments'. The rarity of contact between politicians and administrators is cited as one reason why the former 'lost interest in questions once they had turned from matters of cabinet antagonisms in to administrative grind ${ }^{\prime} .{ }^{\text {to }}$ But this is hardly the case for Irish policy, as huge numbers of administrative papers generated in Dublin Castle at this time have survived, while the papers of the viceroys, Earls

${ }^{5}$ John Morley, The Life of William Ewart Gladstone, 3 vols (London, I908); J.L. Hammond, Gladstone and the Irish Nation (London, I938); H.C.G. Matthew, Gladstone, I809-98 (Oxford, I997); R.F. Foster, 'History and the Irish Question', TRHS, 5th series, 33 (I983), pp. I69-192.

6 A.B. Cooke and John Vincent, The Governing Passion: Cabinet government and party politics in Britain, 1885-86 (Brighton, 1974), p. I7.

${ }^{7}$ Matthew, Gladstone, p. I94, quoting Gladstone to General C. Grey, the Queen's Secretary.

${ }^{8}$ Margaret O'Callaghan, 'Parnellism and crime: constructing a conservative strategy of containment I887-9I', in Donal McCartney (ed.), Parnell: the politics of power (Dublin, I99I), p. I03.

${ }^{9}$ See J.L. Loughlin, Gladstone, Home Rule and the Ulster Question I882-I893 (Dublin, I986) and Alan O'Day, Parnell and the First Home Rule Episode (Dublin, I986).

${ }^{10}$ Cooke and Vincent, Governing Passion, pp. xiii-xiv. 
Spencer and Carnarvon, are testament to the close interest that they, and at least some of their colleagues, took in administrative matters. This volume therefore examines the information supplied to those in power by men who possessed 'a more worm's-eye view' of Irish affairs, and were therefore best informed about the fragile nature of the social and political fabric of Ireland during I884-I886."

Gladstone always denied that there was any question of his experiencing a conversion to home rule. He claimed to regard the issue as a political one that had evolved from the experience of government, and argued that his policy was shaped by the recognition of particular contingencies. Its gestation was a complex process that integrated long-, medium-, and short-term influences, and required not a single moment of decision but 'an assessment of opportunity and "ripeness". An adequate understanding of Gladstone's views on Ireland therefore requires that the precise context of their development should be established. ${ }^{12}$ Drawing upon previously neglected sources, this volume reveals some of the interchanges of information and ideas that lay behind shifts in Irish policy in the mid-I88os. The political journal kept by George Fottrell establishes that important officials within Dublin Castle favoured home rule, an aspect of the question too often ignored in historical accounts of this subject, and supporting documents demonstrate that Gladstone's adoption of home rule was significantly influenced by advice he received from Irish officials. Because he only visited Ireland twice (in 1877 and, briefly, in I880), Gladstone's knowledge of Ireland was derived from informants and advisers. Regarding the accuracy of the reports he received, particularly those relating to clandestine organizations, it can only be said that they represent the best information that was available to his correspondents at the time and, perhaps, that they reflect the imperfect nature of the information available to policy makers when decisions are required of them. ${ }^{13}$ Notwithstanding this, during the last months of 1885, Gladstone was persuaded by those with first-hand experience of Irish affairs that the devolution of political power was urgently required to forestall the growth of Irish separatism and to reach an accommodation that took into account Charles Stewart Parnell's enormous popular support in Ireland.

\footnotetext{
${ }^{11}$ Roy Jenkins, Gladstone (London, I995), pp. 536-537.

${ }^{12}$ Matthew, Gladstone, pp. 464-466.

${ }^{13}$ For useful critiques of Irish police intelligence in this period, see Owen Magee, The IRB: the Irish Republican Brotherhood from the Land League to Sinn Fein (Dublin, 2005), and Margaret O'Callaghan, 'New ways of looking at the state apparatus and the state archive in nineteenth-century Ireland: "Curiosities from that phonetic museum" - Royal Irish Constabulary reports and their political uses, 1879-91', Proceedings of the Royal Irish Academy, I04C, no. 2 (2004), pp. 37-56.
} 
Close examination of the first home rule episode from the perspective of the Irish administration requires re-thinking the commonly held view that Dublin Castle was the exclusive province of reactionary and autocratic bureaucrats. Some historians have observed that the real strength of the Liberal approach to Irish government lay in this official sphere, where the management of affairs resided in the hands of liberal-minded administrators. While the political and administrative relationship between Dublin and Whitehall in this period is a matter of current investigation, much has remained inaccessible to historical inquiry, owing to a lack of memoirs by senior officials and, as has been pointed out, 'unpublicized achievements are easily forgotten'. ${ }^{14}$ Nevertheless, the views articulated by the Irish Under-Secretary, Sir Robert Hamilton, and Edward Jenkinson, the Assistant Under-Secretary for Police and Crime, are striking reminders of the fact that, while Irish government was both over-centralized and unrepresentative, and its vice-regal form of government inconsistent with the principle of parliamentary accountability, the idea that Dublin Castle was simply a sinister, secret, and closed bureaucracy requires careful revision. The views of Hamilton and Jenkinson on Irish government did carry significant weight in I885-1886 and therefore deserve to be more fully considered and widely known than hitherto.

Dublin Castle was a unique apparatus of state, which wielded extensive executive powers. It contained twelve of the more than forty boards, offices, and departments connected with the administration of Ireland, of which the Chief Secretary's Office was the most important. This was the controlling department of most of the branches of Irish government and the mainspring of its administration. As UnderSecretary for Ireland, Hamilton was the permanent head of the Irish executive and was responsible to the Chief Secretary for the routine working of government. He supervised the administration of nearly every public department in Ireland, in accordance with the general policy of the British government. In addition to liaising with the major English departments, the Chief Secretary's Office was above all responsible for law and order and the co-ordination of criminal intelligence. ${ }^{15}$ In August I882, this pressing task was assumed

${ }^{14}$ A.B. Cooke and John Vincent, 'Lord Spencer and the Phoenix Park murders', IHS, I8, no. 72 (September 1973), p. 583, and see Allen Warren, 'Dublin Castle, Whitehall, and the formation of Irish policy, I879-92', IHS, 34, no. I36 (November 2005), pp. 40I-430, which breaks new ground yet neglects the voluminous collections of Irish administrative papers in the National Archives, Dublin.

${ }^{15}$ Kieran Flanagan, 'The Chief Secretary's Office, I853-I9I4: a bureaucratic enigma', IHS, 24, no. 94 (November I984), p. 210; R.B. McDowell, The Irish Administration, I836-I922 (London, 1964), pp. 71-72. 
by Edward Jenkinson, who, like Hamilton, was unfamiliar with the rigours of Irish government when he arrived in Dublin. Yet both men were persuaded by subsequent experiences that it was vital to persuade British politicians to adopt a conciliatory approach to nationalist demands. Their story remains an important yet neglected aspect of the first home rule crisis.

Contemporaries were aware that, during his service in Ireland, Hamilton slowly became convinced of the advisability of home rule from an administrative point of view, and was 'said to have had some share in influencing both his chief, Earl Spencer, and W.G. Gladstone in the same direction'. ${ }^{16}$ Yet this fact has received scant attention in recent historical treatments of the subject. The conversion of Sir Robert Hamilton to home rule is a major feature of the primary manuscript in this volume, the journal kept by George Fottrell during three years of his service as Clerk of the Crown for Dublin (administering to the court of assize). In it he describes his relationship with the Irish Under-Secretary and his role as an agent for the Liberal administration in its confidential dealings with nationalist politicians during the first home rule episode. Fottrell's journal sheds new light on the political crisis of $1885^{-1886}$ and the inner nature of Irish politics in this period. It presents the unique perspective of a man who was, at the same time, a devoted supporter of Charles Stewart Parnell and a crown official with unique access to the Chief Secretary's Office. Fottrell, like others characterized as 'Castle Catholic' fixers, has never been given credit for facilitating discussion of the most contentious political question of the day.

The official documents and private correspondence reproduced in this volume present the perceptions of British officials working in Ireland and shed light upon the efforts that they made to influence the decisions of senior politicians. A close examination of the sequence and substance of contemporary events, as revealed in these papers, provides a fresh perspective on the high-politics conundrum of Irish home rule. Sir Robert Hamilton and Edward Jenkinson each made a persuasive case that, by the end of 1885 , the concession of an Irish parliament was necessary in order to avert a revolutionary crisis in Ireland. The evidence presented here suggests that Gladstone's stance on Ireland was heavily influenced by prevailing doubts about the practicability of persisting with existing constitutional arrangements. This volume therefore offers a fresh perspective on the home rule crisis and places the greatest upheaval in British political alignments between 1846 and 1922 within both an administrative and an Irish context.

\footnotetext{
${ }^{16}$ Dictionary of National Biography: second supplement (London, I912-I913), II, p. $35^{8}$.
} 


\section{The Manuscripts}

Sir George Fottrell's journal was acquired by the National Library of Ireland in I986. ${ }^{17}$ The soft-bound notebook measures $\mathrm{i} 6 \mathrm{~cm} \times 20 \mathrm{~cm}$ and is composed of eighty plain white, paper leaves, of which I 53 sides have been written upon in a reasonably legible hand. It is bound in black leather with gold trim, the outside front cover bearing a fragment of a label and the inside Fottrell's book plate. The manuscript is 50,220 words in length and was compiled between I 3 January I885 and 24 January 1887 , with each entry being clearly dated. The entries were generally made at regular intervals, although there are some temporal gaps that are provided for by Fottrell's summaries of foregoing events. The journal deals almost exclusively with public affairs and social events at which politics were the main topic of conversation. Of Fottrell's family and professional life relatively little has been recorded.

It has been argued that the world of the Victorian politician was a closed and insular one, in which decision making was not confined to Cabinet discussions but was complemented by an informal process of discussion and intrigue. It was to this private institutional world that Fottrell managed to gain access. ${ }^{18}$ His accounts of meeting with members of this inner circle, which included Joseph Chamberlain, John Morley, Sir Charles Dilke, and Randolph Churchill, are characterized by clarity of presentation and pungency of detail and display the qualities of first-hand reportage. The impression Fottrell gives of himself is that of an honest broker - earnest, wellinformed, and guileless - although his role as an intermediary between antagonists did arouse a certain amount of distrust. His journal contains a number of interesting diversions and anecdotes, and its narrative passages give the reader a sense of the uncertain and rapidly changing political climate of Dublin in this period. Fottrell penetrated different circles of political influence in both Ireland and Great Britain and records the interplay between Irish Nationalist, Liberal, and Unionist politicians. His services were prized because, in 1885 , Liberal politicians and administrators had to embark upon a steep learning curve about Ireland as they tried belatedly to establish an information network akin to Lord Randolph Churchill's 'Howth symposium' of Irish Tories. Fottrell's journal re-opens the subject of Joseph Chamberlain and Ireland, and his accounts of conversations with Chamberlain and Lord Randolph Churchill tend to emphasize

${ }^{17}$ NLI, MS 33,670. The journal was presented to the National Library of Ireland by Mrs Rose Sweetman, widow of Gerald Sweetman, TD, who was a descendent of Sir George Fottrell.

${ }^{18}$ Cooke and Vincent, Governing Passion, pp. xi, 2I-22. 
the former's relative ignorance of the subject. Both men, however, recognized Parnell as a powerful and potentially conservative force in Irish politics and Fottrell noted that there was 'remarkably little difference' in their political opinions at that time. While political opportunism played a part in their involvement in Irish affairs, they each displayed, for a time at least, a genuine desire to find a credible settlement of the national question, short of granting home rule. Fottrell's account also challenges the idea that Chamberlain deliberately wrecked a Liberal consensus on Ireland by engineering the central board scheme. ${ }^{19} \mathrm{He}$ casts further light on other relevant issues, such as Gladstone's once reactionary attitude towards Ireland in contrast to Disraeli's more considered approach, and the relevance to Ireland of parallel cases of self-government in Europe and the British Dominions. Overall, he provides a fascinating record of the ways in which both Liberals and Conservatives tried to deal with nationalist aspirations at a time of severe crisis in Anglo-Irish relations.

The other documents reproduced in the present volume refer directly to the matters described and to the issues raised by Fottrell in his journal. The letters and memoranda, many of them produced by Hamilton, Jenkinson, and Fottrell himself, provide insights into how the Irish question was dealt with in the closed worlds of Dublin Castle and Westminster; and they demonstrate that influential figures within this highly specialized community pondered the question of home rule in the light of information that they received from Ireland. The documents are mainly drawn from the Althorp, Carnarvon, Chamberlain, and Gladstone collections held in the British Library, the National Archives, Kew, Birmingham University Library, and the Chief Secretary's Office registered papers in the National Archives of Ireland. Although they represent only a small portion of the huge volume of correspondence and papers generated during the home rule controversy, they shed valuable light on the way that information on Irish affairs was transmitted to both the Conservative and Liberal leaderships.

The idea that English politicians knew little of Ireland and the administrative problems encountered at Dublin Castle was one that was shared by many Irish administrators. At the same time, it cannot be said that Ireland was merely a factor in party alignments and that Irish affairs were hardly reported or discussed. ${ }^{20}$ Lord Spencer's correspondence attests to the close interest that he and his colleagues took in Irish affairs, whether in or out of office, and offers an interesting perspective on their changing attitudes towards Irish governance.

${ }^{19}$ Journal (19 June 1885); Cooke and Vincent, Governing Passion, pp. 34, 39.

${ }^{20}$ Cooke and Vincent, Governing Passion, pp. I7-18. 
This aspect of the home rule question has largely been neglected by historians. A comprehensive biography of Lord Spencer has yet to be written and Peter Gordon's valuable work on his life and correspondence has never received the circulation and attention that it deserves. ${ }^{21}$ The documents presented here reveal much about Spencer's not-ungenerous attitude towards Ireland and help to revise the unsympathetic view of Spencer's second term as viceroy. They shed further light on the political in-fighting that came to overshadow his earlier achievements, when the decisive action he took at the time of the Phoenix Park murders in 1882 saw him emerge as a major political figure. They correct the view that he was 'reactionary, uncreative and inflexible' and reveal him to have been a devoted and tireless administrator who, as John Morley recalled, 'sought the best practical advisors and listened to them'..$^{22}$ The period leading up to the home rule episode was a particular ordeal for this deeply reticent man, as his talents as a governor and his capacity for solving difficult administrative problems were frustrated and compromised by political manoeuvring for which he had little talent. Although Spencer went on to hold high office in later Liberal administrations, he paid a heavy social price for supporting home rule and was regarded in aristocratic circles 'as an especial traitor'. ${ }^{23}$

\section{The Liberals and Ireland, $1880-1884$}

Gladstone's journey on the path to home rule began when he inherited the Irish Land War upon returning to office in May i88o. The Land League's campaign, which has been described 'as near a revolutionary movement as anything seen in the United Kingdom between I80o and I9I4' was met first with repression and then by the concession of the Land Act in April I88I. ${ }^{24}$ The conflict was largely resolved a year later when, after violence had escalated in the countryside following the suppression of the Land League, a compromise was reached with the League's leadership in the so-called Kilmainham Treaty. This settlement was almost immediately overturned by the assassination of the Irish Chief Secretary and Under-Secretary in Dublin, an event

\footnotetext{
${ }^{21}$ Peter Gordon (ed.), The Red Earl: the papers of the fifth Earl Spencer 1835-19I0, 2 vols (Northamptonshire Record Society, I98I and I986).

${ }^{22}$ Cooke and Vincent, 'Lord Spencer', p. 584; John Morley, Recollections, 2 vols (London, I923), I, p. 220.

${ }^{23}$ George Askwith, Lord Fames of Hereford (London, I930), p. I89; Charles Spencer, The Spencer Family (London, I999), pp. 278-280.

${ }^{24}$ Matthew, Gladstone, p. 442, and see Allen Warren, 'Forster, the Liberals and new directions in Irish policy, I880-I882', Parliamentary History, 6 (1987), pp. 95-I26.
} 
which ushered in three years of less severe repression, characterized by the measured use of the Prevention of Crime Act, and the concession of further reforms. During this period, conflict in Ireland was largely confined to the political arena and was characterized by the bitter criticism of the Liberal administration made by Parnell's followers in Westminster, on the public platform, and in the Irish press.

During the Land War, elements within the Irish home rule party had been severely compromised by their apparent association with agrarian crime. Therefore, when the immediate crisis that followed the Phoenix Park murders subsided, the Chief Secretary for Ireland, George Trevelyan, announced that the administration intended to 'draw a deep line between what is criminal and what is political'. He declared that lawful political activity would not be the concern of government but promised to use emergency executive powers to wage 'an undying and unrelenting war' against subversion and crime and so 'guard the operation' of the recent land reforms. ${ }^{25}$ However, the simple juxtaposition of moral force and physical force in Ireland was always a gross oversimplification because, at times of social strife, the relation between the two was largely symbiotic. ${ }^{26}$ In the absence of a satisfactory land settlement, such conditions were never far away. Gladstone's desire to maintain the social role of an overwhelmingly Protestant landowning class as an element of order in Ireland had retarded the development of an effective land purchase scheme. The idea of joint proprietorship embodied in the I88I Land Act had been tactically successful but soon became the 'salient point of friction' between landowner and tenant. Rent disputes continued to be a frequent cause of disorder and the National League, established from the ashes of the Land League in October 1882, made the establishment of peasant proprietorship their primary objective. The continuation of land agitation placed a prolonged burden on Dublin Castle and ensured that Irish social and political life continued to be closely regulated. Intensified policing inevitably created friction both in Ireland and at Westminster, where the actions of the authorities were challenged by an ever more tightly organized Irish nationalist party. As Matthew has concluded, the use of coercion to uphold Irish landowners 'guaranteed the demise of Liberalism in Ireland' and became 'the treadmill on which the Liberal party ran from i88o to I885. $\cdot^{27}$

${ }^{25}$ The Times, 24 August 1882 , p. 4.

${ }^{26}$ Matthew, Gladstone, p. $45^{6 .}$

${ }^{27}$ Ibid., pp. 444, 446, 450-45I; Allen Warren, 'Gladstone, land and social reconstruction in Ireland, I88I-I887', Parliamentary History, 2 (1983), pp. I53-173. 
By the spring of i884, the attempt to distinguish clearly between politics and crime already appeared to be failing. As a consequence, at least one Irish official was warming to the idea of home rule and recognized that Irish nationalism had become integrated into the fabric of British politics, just as its representatives had become 'progressively enmeshed in parliamentary affairs' ${ }^{28}$ Acceptance of Parnell as a permanent fixture on the political landscape of the United Kingdom is nowhere more apparent than in the correspondence between Edward Jenkinson and Lord Spencer. By i884, Jenkinson had identified what he regarded as the reformist tendency within the Irish nationalist movement, and was impressed by Parnell's willingness to seek a constitutional settlement of Irish grievances within the British parliamentary system. ${ }^{29} \mathrm{He}$ had also come to believe that the Government's employment of exceptional legal powers in Ireland, while justified in the short term, had not removed the causes of Irish disaffection and would not eradicate disorder. ${ }^{30}$ His conviction that the Liberals were pursuing a fruitless policy in Ireland deepened during the second half of i884. The Crown's efforts retrospectively to punish crimes committed during the Land War through expanded police powers and alterations to trial procedures, along with irksome controls over the press and public meetings, provoked a stream of criticism. In the two years after August 1882, more than one hundred separate attacks were made upon the administration of justice in Ireland by MPs, including damaging charges that legal officers had displayed sectarian bias in the selection of juries and that innocent men had been sent to the gallows. ${ }^{31}$ By the middle of 1884 , the reputation of Dublin Castle had fallen to a low point as a result of sexual scandals involving senior government officials, including the former Detective Director of the Royal Irish Constabulary. ${ }^{32}$

Wider changes in the political landscape of the United Kingdom increased Jenkinson's anxiety about Liberal policy in Ireland. Franchise reforms were set to increase greatly the size of the Irish electorate by granting voting rights to small farmers and landless

${ }^{28}$ O'Day, First Home Rule Episode, p. 85.

${ }^{29}$ Alan O'Day, Irish Home Rule I867-I92I (Manchester, I998), p. 85.

${ }^{30}$ See Document r. He informed General Sir Garnet Wolseley that the existing administrative machinery made the management of Ireland 'very hopeless work': Elizabeth A. Muenger, The British Military Dilemma in Ireland: occupation politics, I866-I9I4(Dublin, I99I), p. 7o, quoting Jenkinson to Wolseley, 20 January I884.

${ }_{31}^{1}$ 'Return of attacks made by Irish MPs on the administration of justice of Ireland, I882I884'; Harcourt to Spencer, 29 October I884; Spencer to Harcourt, 30 October I884: AP, Add MSS 77330, 76933 .

${ }^{32}$ Spencer to Gladstone, 7 and II March I884; Spencer to Horace Seymour, 9 March I884: AP, Add MS 76859; Frank Callanan, T.M. Healy (Cork, I996), pp. 89-92. 
labourers. It was anticipated that this would secure for Parnell fourfifths of Ireland's parliamentary representation at the next general election. The Liberals had faced a dilemma over this question: under the Franchise Act of 1850 , only one in six adult males was allowed to vote in Irish parliamentary elections and, in October I883, Gladstone questioned whether a larger electorate would be 'favourable or unfavourable to the interests of ultra-nationalism'. Spencer argued that the omission of Ireland from the franchise reform would present Parnell with a 'new \& real' grievance. He was supported by Lord Northbrook, who, after consulting Jenkinson (his cousin), was convinced that this would strengthen the hand 'of the more violent of the nationalists, perhaps even those of the dynamite lot' ${ }^{33}$ The Liberals therefore had to face the probability that Ireland would henceforth be entirely divided between Nationalists and Conservatives. In the circumstances, Jenkinson believed that a radical departure in Irish policy was required. On 24 September 1884, he urged Spencer to 'lead England on the Irish question' by acknowledging the Irish aspiration for self-government. He argued that home rule was the 'true solution of the difficulty' and 'the only remedy for Fenianism and Dynamite outrages', and concluded that it would be better if the British presented home rule as 'a gift' rather than have it wrung from them by force. ${ }^{34}$

\section{George Fottrell, Joseph Chamberlain, and Local Government Reform}

By this time, Spencer had become disillusioned with his role in Ireland and believed that the conditions that had made his presence there necessary no longer pertained. ${ }^{35}$ As a born administrator, Spencer had an aversion to party politics. He baulked at the prospect of further criticism from the Irish party and believed that his freedom of action was increasingly circumscribed by critics within the Liberal Party. Whereas he had once been certain that English public opinion accepted the 'absolute necessity of repression' in Ireland, he felt that misgivings within the party over its continuation could not be ignored and acknowledged that there was 'no impetus of public opinion' to

\footnotetext{
${ }^{33}$ Gladstone to Spencer, I9 October I883; Spencer to Gladstone, 20 October i883; Northbrook to Spencer, 26 November I883; Spencer to Northbrook, 29 November I883: AP, Add MSS 76858, 76918.

${ }^{34}$ See Document 4.

${ }^{35}$ Horace Seymour to Spencer, 25 July I884: AP, Add MS 76859. Seymour was private secretary to Gladstone and Spencer's brother-in-law.
} 
help him through his present difficulties. ${ }^{36}$ When Jenkinson wrote to him in September, Spencer found himself 'in the midst of dreadful abuse' from Irish MPs, with the nationalist press being 'violent and abusive beyond all precedent'. Nevertheless, he refused to 'run away from Irish difficulties' and assured Gladstone that he would remain in Dublin. ${ }^{37}$ Much, therefore, depended upon the formulation of a policy that recognized that resistance to the law in Ireland had been superseded by organized political opposition to the system of government. Jenkinson believed that it was important that the Liberals advertised their good intentions toward Ireland in order to reach a settlement with moderate home rulers before the Conservatives regained power. Spencer realized that he had got into 'hopeless antagonism' with the Irish Parliamentary Party, which made it difficult for him openly to accept the force of the nationalists' arguments. He felt unable to acknowledge Parnell as the leader of Irish opinion given that, as he informed Edward Hamilton, 'he never approaches me and I cannot approach him' ${ }^{38}$ A means of communicating with the nationalist leadership was clearly required and so, in early October, Sir Robert Hamilton recommended the appointment of George Fottrell as Clerk of the Crown for the County and City of Dublin. This thirtyfive-year-old graduate of the Catholic University was a successful Dublin solicitor, who had been active in support of Parnell and his party. He was already known to Liberal ministers, having spent a brief and controversial spell as solicitor to the Irish Land Commission in I88I-I882. ${ }^{39}$ And, as Jenkinson had suggested, it was to moderate nationalists like Fottrell that the Government had to turn if it was to solve the problems of Irish government.

Any accommodation of the Irish party depended upon making the system of government more acceptable to the majority of the population. For the first thirty years of the Union, the machinery of government in Ireland had been recruited almost exclusively from that section of the Protestant community 'most unpopular with the mass of the people'; appointees' claims to preferment rested on their loyalty to the constitutional arrangement that had brought the Castle system into being. By failing to offer a measure of Catholic participation in its workings, it has been argued, any chance of building popular confidence in Irish government and thus securing popular acceptance

\footnotetext{
${ }^{36}$ Seymour to Spencer, 25 July I884; Spencer to Seymour, 30 July 1884: AP, Add MS 76859 .

37 Spencer to Harcourt, I4 September I884; Spencer to Gladstone, 26 August I884; Spencer to Seymour, 30 July i884: AP, Add MSS 76933, 76860, 76859 .

${ }^{38}$ Spencer to Landsdowne, i6 August I885, repr. RE, II, pp. 70-74; Spencer to Edward Hamilton, 23 September 1884: AP, Add MS 76860.

${ }^{39}$ See Appendix, p. 323.
} 
of the Union was missed..$^{40}$ In spite of the introduction of merit as the basis of entry to the civil service in the mid-I85os, patronage continued to play an important part in the recruitment of senior officials, and the distribution of patronage was entangled with party and personal considerations. Lord Spencer, however, believed that 'ability, simple clearness of mind, honesty of purpose and strict impartiality' were the chief qualities required of public servants. In I87I, he declared that the principle upon which he acted was 'never exclude a fit man on account of his religion, but do not on account of his religion give him a place which another is better fitted to hold'. ${ }^{4}$

Fottrell's appointment also owed much to Spencer's desire to display greater probity in his appointment of legal officials. When the clerkship became vacant in the summer of 1884 , Hamilton had initially wanted to appoint Samuel Anderson, a crown solicitor who, since I865, had been intimately involved in the investigation and prosecution of Fenianism. After Anderson's octogenarian father had been forced to stand down as Crown Solicitor for Dublin, the son began to lobby for his position. Because Spencer wanted 'new blood' in the post, Hamilton proposed to compensate Anderson with the clerkship for Dublin..$^{22}$ The Chief Secretary, however, objected to the appointment of a man widely regarded as 'the personification of a Castle man' and who appeared to be bargaining for appointments in a highly unethical way. ${ }^{43}$ Anderson was notorious in Ireland for 'packing' juries on behalf of the Crown, and Trevelyan complained that parliamentary debate of the issue had brought the Government close to disaster. ${ }^{4+}$ Fottrell benefited from this dilemma and assumed his new duties on 8 October. His appointment exemplified the growing influence of Catholic professionals within national administration and was, perhaps, the earliest example of the Liberal policy of 'greening' Dublin Castle in anticipation of Irish home rule. ${ }^{45}$

${ }^{40}$ Gearoid O'Tuathaigh, Ireland Before the Famine, $179^{8-1848}$ (Dublin, I990), p. 83.

${ }^{41}$ Spencer to Thomas O'Hagan, 2 November I87i: PRONI, O'Hagan Papers, D 2777/8/I59. O'Hagan was the first Catholic to be appointed Irish Lord Chancellor in the modern era.

${ }^{42}$ Spencer to Hamilton, 28 July I884; Hamilton to Spencer, 28 July I884: AP, Add MS 77059 .

${ }^{43}$ He informed Spencer that Anderson had 'been talking about how much he knows etc.': Trevelyan to Spencer, 28 and 3r July 1884; Hamilton to Spencer, 29 July i884: AP, Add MSS 76964, 77059 .

${ }^{44}$ Hamilton to Spencer, 4 September I884; Trevelyan to Spencer, ${ }_{5} 5$ August I884; Spencer to Trevelyan, 21 August I884; Hamilton to Spencer, Io, II, and I4 October I884: AP, Add MSS 77059, 76965, 77060. Anderson retained his crown solicitorship and received a knighthood: Daily Newes, 28 October I884, p. 3.

${ }_{45}$ United Ireland, 28 October I882; CSO RP I884/22365; and see Lawrence W. MacBride, The Greening of Dublin Castle: the transformation of bureaucratic and judicial personnel in Ireland, I892-I922 (Washington, DC, I99I). 
In December i884, Hamilton told Fottrell that Spencer wanted him to ascertain privately the views of his acquaintances in the Irish Parliamentary Party on questions of government. Fottrell replied that, while he was not prepared to 'pump' his acquaintances for information or betray any confidences, he would attempt to make 'each side acquainted with the views of the other so as to promote harmony between them' ${ }^{46}$ Fottrell's acquaintance with both progressive Liberals, such as John Morley and Charles Russell, and many leading Parnellites made him an ideal intermediary. As his journals demonstrate, he proved to be an important source of intelligence for the Dublin administration during the home rule crisis of I885-1886.

Fottrell's appointment coincided with the beginning of the end of Gladstone's second administration, as it tried unsuccessfully to resolve internal differences over Ireland. Prior to Fottrell's appointment, Spencer had not been under any pressure to concede to nationalist demands, largely because of improved economic conditions. In February i884, Spencer reported that boycotting had almost ceased and the 'tone and demeanour of the people' had greatly improved. At the same time, the RIC suggested that 'secret intimidation' was still being exercised by secret societies in the south-western counties, where, Spencer admitted, the Irish authorities had to 'keep a firm hand to repress outrages'. ${ }^{47} \mathrm{He}$ therefore planned to re-enact several sections of the Crimes Act, which was due to expire in August I885. Meanwhile, the question of local government reform rose to prominence. In December i884, Joseph Chamberlain responded to favourable reports on the condition of Ireland by floating a scheme for locally elected councils and a representative central board in Dublin that would control education, the poor law, sanitation, and public works..$^{8} \mathrm{He}$ argued that this was the only acceptable alternative to home rule, and claimed to have Parnell's approval for the scheme. ${ }^{49}$ Fottrell informed Hamilton about this development and supplied him with a copy of Chamberlain's proposals, but the scheme caused considerable unease in Dublin. Spencer had long suspected that Chamberlain was planning to create 'a New Party' when Gladstone retired, and simply

\footnotetext{
${ }^{46}$ Journal (13 January $\left.\mathbf{1 8 8} 5\right)$.

${ }^{47}$ Spencer to Lord Granville, 3 February I884; Spencer to Gladstone, 26 August I884; Spencer to Granville, 22 October 1884: AP, Add MSS 76884, 7686o.

$4^{8}$ W.H. Duignan to Chamberlain, 24 October I884; Chamberlain to Duignan, I7 and I9 December I884:JCP, JC8/3/I/ı, 24, 25. See also C.H.D. Howard, 'Joseph Chamberlain, Parnell and the Irish "Central Board" scheme, $\mathrm{I}_{88}-5$ ', and 'Documents relating to the Irish "Central Board" scheme, I884-5', IHS, 8, no. 32 (September I953), pp. 324-36r, 240-242.

${ }^{49}$ This claim later caused controversy between Chamberlain and Parnell: see Journal (3 January 1887); Howard, 'Joseph Chamberlain', p. 325; William O'Shea to Chamberlain, 9 August i888: NLI, MS 5752, fos $33^{8-} 34^{2}$, 358-359.
} 
interpreted the central board scheme as an attempt to divide Liberal opinion over the Irish question..$^{5}$

Spencer believed that a new crimes bill should be the Government's first priority and so, on I3 January I885, he consulted his law officers and police officials, who confirmed that certain core powers could not be safely abandoned..$^{1}$ Hamilton urged Spencer to retain some of the most controversial sections of the Crimes Act, including those covering police searches, the prohibition of public meetings, and the suppression of newspapers. Nevertheless, Spencer recognized the limitations of coercion, and acknowledged that overreliance on emergency powers had obstructed the improvement of relations between the administration and the bulk of the Irish people. The recent extension of the franchise had made it difficult to ignore Irish demands for a more democratic and accountable system of government. ${ }^{2}$ Spencer admitted to William Harcourt that government 'by force' was 'odious, and cannot be carried out forever'. If it were ever to become necessary, he added, 'then let us do away with our constitutional forms at once and govern Ireland like India'. This, he conceded, was currently 'impossible' and the only alternative was 'to do all you can to remedy real grievances and, while maintaining law and order, to gradually bring them over to our side'. By supplementing a crimes bill with local government and land purchase reforms, Spencer hoped to diminish the appeal of home rule to 'more moderate nationalists' and overcome the objections of Ulster Liberals to the continuation of coercion..$^{53} \mathrm{He}$ attached great significance to the spread of Parnellism among public bodies, which had recently manifested itself in a more assertive approach towards Dublin Castle from municipal corporations, which had culminated in Limerick Council's refusal to pay police tax. He therefore favoured measures that might break the perceived connection between the actions of the political ministry and the authority of the Crown. ${ }^{54}$

In February, Hamilton asked Spencer to seek a swift resolution of the Cabinet's difficulties over Ireland in order to forestall further parliamentary criticism of the Irish administration. Spencer

\footnotetext{
${ }^{50}$ Howard, 'Joseph Chamberlain', pp. 332-338; Howard, 'Documents', pp. 242-248; Spencer to William Harcourt, 26 January I883: HP, Dep $4 \mathrm{I}$; Journal (30 January 1885).

${ }^{51}$ Courtney Boyle, 'Minutes of meeting on Crimes Act', I3 January 1885: AP, Add MS 7733. The meeting was attended by Spencer, Henry Campbell-Bannerman, Jenkinson, the Solicitor- and Attorney-Generals, and two divisional magistrates.

${ }^{52}$ Robert Hamilton, 'Renewal of the Crimes Act', i8 January i885: AP, Add MS 77331; Spencer to Campbell-Bannerman, 25January I885: AP, Add MS 76868.

${ }^{53}$ Spencer to Harcourt, I9 January I885; Spencer to Granville, 25January I885: AP, Add MSS 76933, 76884 .

${ }^{54}$ See 'Limerick Police Tax', 6 November 1884: AP, Add MS 77318A; Spencer to Gladstone, 26 January i885: AP, Add MS 7686r. He suggested that the viceroy be replaced by a secretary of state and that a royal residency be established in Ireland.
} 
responded by preparing two Cabinet memoranda, the first outlining his legislative proposals and the second evaluating each section of the Crimes Act. ${ }^{55}$ Gladstone welcomed a fresh approach to Irish government but decided that Spencer's proposals to abolish the viceroyalty and extend land purchase were not feasible at that time. His plan to extend the jurisdiction of a new crimes bill to the entire United Kingdom also had to be abandoned after the English Law Officers pronounced it unworkable. In order to expedite matters, Gladstone formed a Cabinet committee, composed of Spencer, Campbell-Bannerman, Lord Carlingford, Trevelyan, Harcourt, and Chamberlain, to discuss the framing of Irish legislation. ${ }^{56}$ When the committee convened in late April, however, its discussions were hampered by the fact that prior communication between Spencer and Chamberlain had broken down, the significant differences in their respective positions having emerged only the day before. ${ }^{57}$ It rapidly became clear that opinion on the Crimes Act was hopelessly polarized. The experience of seeing many poor law guardian boards fall into the hands of nationalists and Land Leaguers during I880-I882 had made Spencer cautious about wide-ranging local government reform. He argued that it would merely re-ignite political agitation in Ireland, arouse Conservative opposition at Westminster, and antagonize landowners without having the virtue of satisfying the Irish nationalists. ${ }^{5^{8}}$

Spencer's reluctance to trust Parnell played a large part in his reluctance to accept administrative reform. He had long endured what he regarded as unjustified personal criticism from Irish nationalist politicians. He deeply distrusted the Parnellites and this proved to be an enduring obstacle to his acceptance of the validity of what, in September I884, he termed "the cant phrase "Home Rule". He was prepared to consider a 'scheme to create a transitional form

${ }^{55}$ Hamilton to Spencer, 25 February i885: CSO, RP I885/I4456; Spencer, 'Legislation for Ireland' and 'Prevention of Crime (Ireland) Act, I882', 23 March I885: CAB 37/I4/19, $\mathrm{CAB} 37 / \mathrm{I} 4 / 20$.

${ }^{56}$ Spencer to Edward Hamilton, I 8 March I885; Gladstone to Spencer, I 8 and 30 March I885; Edward Hamilton to Spencer, 27 April I885: AP, Add MSS 7686r, 76862; Dudley W.R. Bahlman (ed.), The Diary of Sir Edward Walter Hamilton, 2 vols (Oxford, I972), II, p. 862. The committee was to consult Lord Hartington, Hugh Childers, and George Shaw-Lefevre on the question of local government.

${ }^{57}$ See Edward Hamilton to Spencer, 2I March I885; Gladstone to Spencer, 3o March I885; Spencer to Edward Hamilton, 25 April I885; Spencer to Gladstone, 26 April I885; Spencer, 'Notes of what passed re. Crimes Act in May i885', i9 May I885: AP, Add MSS 7686I, 76862, 77319. See also Bahlman, Edward Walter Hamilton, II, p. 852.

$5^{8}$ Spencer to Granville, 28 January I883; Spencer to Harcourt, I5January I883: AP, Add MSS 76882, 76930; William L. Feingold, The Revolt of the Tenantry: the transformation of local government in Ireland 1872-1886 (Boston, MA, 1984). 
of government', providing that it could not be interpreted as the product of nationalist pressure, but feared that Chamberlain's scheme raised 'the danger of a Convention'. He warned Gladstone that it would be folly to establish a central authority that might behave as a rival centre of power in Ireland, and one likely to be dominated by men who had, he believed, 'shown themselves so incapable of governing Ireland by their vehemence of language and action, and their persistent efforts to break down law and order'. ${ }^{9}$ Spencer was firmly supported by Hamilton, whose own suspicions had been aroused by Parnell's endorsement of Chamberlain's scheme. At this point, both men still regarded the Parnellites as quasi-republicans and predicted that a central board would merely promote 'anarchy and separation', paralyze the Irish executive, and further embitter relations between Britain and Ireland. ${ }^{60}$

At Westminster, opinion on the question remained divided, but Spencer's reputation as an experienced Irish administrator ensured that Chamberlain's proposals were rejected, albeit by a slim majority, on 9 May. Over the following weeks, Spencer and Chamberlain continued to negotiate over Irish legislation, but it was already known that Lord Randolph Churchill had indicated to Parnell that a Conservative administration would not renew the Crimes Act. All the same, three alternative crimes bills, each designed to modify trial procedures and perfect the Irish police system, were considered by the Cabinet on 2I May. ${ }^{61}$ Shortly afterwards, Sir Charles Dilke took advantage of a visit to Dublin to seek a compromise on the question of local government. He recorded that Hamilton 'offered as a maximum county boards plus a General Education Board for Ireland to administer all the grants with rating powers and to [be] called a great experiment to be extended if it answered'. Spencer went further and offered four elective provincial boards to discharge many of the duties that Chamberlain had intended to assign to the Central Board, but, lamented Dilke, he 'obstinately refused to take the plunge of making the four Boards into one Board'. ${ }^{62}$ On the other hand, when John Morley visited Dublin a few days later, he had found Spencer 'querulous', whereas his discussion with Hamilton, he informed Chamberlain, had pleased him better. Nevertheless, Gladstone correctly suspected that Spencer's intransigence over

\footnotetext{
${ }^{59}$ Document 5; Spencer to Gladstone, 30 April and io May i885: AP, Add MS 76862.

${ }^{60}$ Document 9; Spencer, 'Memorandum. Proposed Irish legislation', c.April I885: AP, Add MS 77319.

${ }^{6 r}$ Bahlman, Edward Walter Hamilton, II, p. 859; Henry Thring, 'Procedure for Trial (Ireland) Bill. Memorandum', 8 June I885: AP, Add MS 7733I.

${ }^{62}$ Sir Charles Dilke's diary, 25 May I885 (copy): JCP, JC8/2/r.
} 
coercion was in part due to the influence of Dublin Castle. On 6 June, Hamilton, concerned that falling agricultural prices would prevent tenant farmers from drawing further benefit from the Land Act, advised Spencer not to part 'with any power which helps us to deal with [boycotting], or allow the idea in any way to prevail that intimidation in itself is not a crime' ${ }^{6}{ }^{{ }_{3}}$ Chamberlain, however, insisted upon Cabinet control over any new Crimes Act, thus making it a potential rather than an operative statute. This move was countered by Spencer who, acting upon Hamilton's advice, declared that present conditions made it likely that most of Ireland would have to be proclaimed upon the bill becoming law. The consequent deadlock was only resolved when a defeat in the Commons over the taxation of beer and spirits gave the ministry an opportunity to resign. ${ }^{64}$

Fottrell had been kept abreast of negotiations over the Crimes Act by John Morley and Thomas Escott, the editor of the Fortnightly Review and a confidant of Joseph Chamberlain. ${ }^{65}$ Dilke had also consulted him about the central board scheme during his visit to Dublin and was clearly impressed by Fottrell, recording that he and Hamilton 'were the only two men who counted in that city'. Consequently, on the day that the Liberal administration resigned, Chamberlain asked Fottrell to supply him with information on the structure of local government in Ireland ${ }^{66}$ Chamberlain was collaborating with Escott on the final parts of what would be published as The Radical Programme and, having already drafted an article on local government in Great Britain, Escott asked Fottrell to supply an equivalent article on Ireland for the Fortnightly Review. ${ }^{67}$ Fottrell completed his article in just three days and subsequently met twice with Chamberlain to discuss its contents. Fottrell also raised the question of local government with

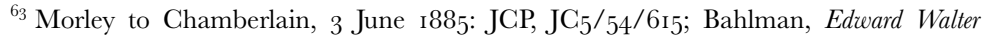
Hamilton, II, p. 876; Hamilton to Spencer, 6 June I885: AP, Add MS 7706o.

${ }^{64}$ Gladstone to Spencer, 5 June i885; Spencer to Gladstone, 6 June I885; Hamilton to Spencer, 6 June I885; Spencer, 'Further notes as what passed re. Crimes Act', 22 June I885: AP, Add MSS 76862, 77060, 77319. Spencer was advised that the position of Ulster Liberals would improve if the province remained free from the Act: Campbell-Bannerman to Spencer, 5 June I885: AP, Add MS 76871.

${ }_{55}^{6}$ See Journal (I-31 May 1885).

${ }^{66}$ See Journal (26 May 1885); Gwynn and Tuckwell, Sir Charles W. Dilke, II, p. I57; Document Io. The two became acquainted after Fottrell served on the Irish Land Commission and subsequently corresponded on aspects of the land question: Fottrell to Chamberlain, 30 May 1882: GP, Add MS 44475, fos 210-219; Chamberlain to Fottrell, 6 June I882:JCP, JC8/4/I/I.

${ }^{67}$ Joseph Chamberlain, A Political Memoir I880-92, edited by C.D.H. Howard (London, I953), p. Io8.
} 
Randolph Churchill at a meeting that Dilke, from whom Churchill then had few political secrets, brought to the attention of Gladstone. ${ }^{68}$

However, Chamberlain's relationship with Fottrell proved to be a liability when he and Dilke proposed to visit Ireland to, as he explained to Michael Davitt, 'see for ourselves something of the present condition of the country \& to obtain [...] a full expression of the wishes $\&$ wants of the people' ${ }^{69}$ While Fottrell was 'well regarded by most of the Irish party', he had some enemies within its ranks. Notable among these was Timothy Healy, who, according to William O'Shea, detested Fottrell. In spite of opposition from Parnell, Healy framed a leader for United Ireland assailing his local government scheme. ${ }^{70}$ Subsequent attacks on Chamberlain by United Ireland were approved by Parnell, who no longer wished to pursue the national councils scheme, and led to the abandonment of Chamberlain's planned visit to Ireland. Chamberlain had been optimistic that his local government scheme would meet Irish demands and was exasperated by the turn of events. ${ }^{71}$ He complained to Davitt,

For a long while past it had been customary for Irishmen to complain, not without reason, that English politicians took no steps to ascertain on the spot the real wishes and opinions of the Irish people; and it certainly seems strange commenting on this complaint that the first two Englishmen who endeavour to relieve themselves from this reproach should be met with insult \& offensive imputation..$^{72}$

Although Chamberlain later denied that he developed a personal enmity towards Parnell for abandoning the central board scheme, or that it became the 'stimulating cause' of his opposition towards home rule, Fottrell was to find Chamberlain markedly less sympathetic to his views from this point on. ${ }^{73}$

\section{Sir Robert Hamilton and Home Rule}

The collapse of the Liberal ministry proved to be a turning point in the development of Sir Robert Hamilton's views on Irish government.

${ }^{68}$ Journal (17, 19, 23 June 1885); J.L. Garvin, The Life of Joseph Chamberlain, 2 vols (London, I933), I, p. 546; Dilke's diary, I3 July I885 (copy): JCP, JC/8/2/I; Roy Foster, Lord Randolph Churchill: a political life (Oxford, I98I), p. 23 I.

${ }^{69}$ Chamberlain to Davitt, I July i885: TCD, Davitt Papers, MS 9374/983.

${ }^{70}$ O'Shea to Chamberlain, I3 July I885: JCP, JC/8/8/I/50; T.M. Healy, Letters and Leaders of My Day, 2 vols (London, i89o), I, pp. 249-250; Chamberlain, Political Memoir, p. I54; Callanan, T.M. Healy, pp. II8-120.

${ }_{71}$ Journal (5 August 1885); Chamberlain to O'Shea, i July i885: JCP, JC/8/8/ I/49.

${ }_{72}$ Chamberlain to Davitt, I July i885: TCD, Davitt Papers, MS 9374.

${ }^{73}$ Chamberlain to Davitt, 8 June I9o3: TCD, Davitt Papers, MS 9374. 
The conversion of Hamilton and, subsequently, of Lord Spencer to home rule mystified supporters of the national council scheme. As Dilke put it, 'I confess that I have never been able to understand why Hamilton and Spencer held out as they did in May against the moderate scheme and have supported the extreme one'. ${ }^{74}$ Indeed, for two weeks after Gladstone's departure from office, the Irish Under-Secretary continued to paint an alarming picture of the state of Ireland. He realized that the opportunity to correct 'defects in the existing machinery of the law' had now passed and feared that boycotting and intimidation would soon result. Hamilton also sensed an air of demoralization within the Constabulary and warned that 'another outbreak of crime would throw back the country terribly'. ${ }^{75}$ He viewed the future of Ireland 'with the gravest apprehension', and claimed, 'The spirit of the people has not changed. Those who terrorized the country with impunity three years ago are as ready as ever to embark on the same course again.' A fresh outbreak of agrarian crime would, he feared, discredit the executive government and indefinitely retard the progress of the country towards quiet and prosperity'. Nevertheless, by the time the Conservative ministry took office, Hamilton had come to accept that the political obstacles to further coercion were insurmountable and was persuaded that Parnell's recent accommodation with the Conservatives would reduce the threat of disorder. ${ }^{76}$ Within weeks, Hamilton had not only dropped the idea of further coercing Ireland, but had also embraced home rule as the only practical solution to the country's ills.

While his time with the Irish Civil Service Committee in I874 would have provided Hamilton with some insight into the machinery of Dublin Castle, he knew relatively little of Ireland's history and political culture. Fottrell's assertion that Hamilton's want of acquaintance with the Manchester Martyrs controversy of 1867 'was a very strong argument in favour of Home Rule for Ireland' struck the UnderSecretary with some force. ${ }^{77}$ Hamilton's growing friendship with Fottrell was the catalyst for his conversion to home rule, and he frequently drew upon the young lawyer's expertise in key areas such as legal procedure, education, local government, and land reform. As a result, his views on Irish government changed dramatically during the late summer of 1885 .

\footnotetext{
${ }^{74}$ Dilke's diary, postscript to 25 May I885 (copy): JCP, JC/8/2/I.

${ }^{75}$ Hamilton to Campbell-Bannerman, I5 June I885: CBP, Add MS 4I232, fos I24-I25; Journal (27 June 1885).

${ }^{76}$ Hamilton, Memorandum, i8 June I885: AP, Add MS 77060; Hamilton, Memorandum on agrarian crime, $c$.June I885: CP/TNA, PRO 30/6/64 (9).
}

${ }^{77}$ Journal (24 May 1885). 
Hamilton's conversion would have surprised many Liberals given the staunch support that he had given Spencer over coercion and local government in the spring. He had then been confident that Ireland could be pacified by moderate reform supported by a limited number of emergency powers and had therefore encouraged Spencer to resist the claims of militant nationalism. He believed that, by acquiescing to 'legitimate grievances' over land and local government, the Liberals might still divide the nationalist movement between those he described as the 'many honourable men who belong to it' and the fringe of 'born criminals who delight in crime'. The extent of selfgovernment favoured by Hamilton at this time was, however, still quite limited and he regarded the measure, at least in part, as one means of defeating the National League. In conceding a measure of local government, he advised Spencer, 'you will then have cut the heart out of the combination, which is already weakened by the recent land legislation'. ${ }^{78}$ Nevertheless, Hamilton had long believed that greater state intervention in Ireland was necessary to stimulate economic development and improve agriculture and transport. ${ }^{79} \mathrm{In}$ February I885, having discussed the matter with moderate nationalists such as Edward Dwyer Gray, Hamilton had produced a Cabinet paper that advocated the development of 'free local government' in Ireland and, two months later, he prepared a scheme for converting the National Education Board into a representative body. ${ }^{80}$ Yet the sea change in Hamilton's attitude to home rule was largely due to his being made familiar with the opinions of leading Irish nationalists courtesy of Fottrell's social arrangements. Indeed, Hamilton confessed to Fottrell that his home was 'the only place where he was able to meet men in touch with the people'. An important turning point came on 27 July, when Fottrell introduced Hamilton to Sir Charles Gavan Duffy, the veteran Irish nationalist and former prime minister of Victoria. Over the course of two meetings, Gavan Duffy convinced Hamilton of the urgent need to establish a separate Irish parliament in advance of local government reform. The appeal of Gavan Duffy's proposals lay in their legislative safeguards for Irish landowners and the Protestant minority, and an assurance that Parnell's underlying social conservatism would be the dominant influence in an Irish parliament. Hamilton admitted to being 'greatly struck' with what he

\footnotetext{
${ }^{78}$ Hamilton, 'Renewal of the Crimes Act', I8 January i885; Hamilton, Memorandum, I8 June I885: AP, Add MSS 7733I, 77060. For Hamilton's proposals, see Document 9.

${ }_{79}$ Spencer to Gladstone, 22 May I883, containing memorandum from Hamilton: GD, X, p. 45 I.

${ }^{80}$ See Hamilton, 'Local government of Ireland', in February 1885: CAB 37/14/9.
} 
heard and passed his report to Lord Carnarvon who, unbeknownst to Hamilton, had already arranged to meet with Parnell. ${ }^{81}$

\section{The Irish Situation, $1884-1885$}

At this time, the Irish Republican Brotherhood appeared to be serving the wider political interests of Parnellism. On the other hand, Clan-na-Gael, its American counterpart, had retained its freedom to act independently, which made Jenkinson anxious about recent developments in the United States. In August 1884, he learned that the annual convention of the Irish National League of America in Boston had been so completely dominated by Clan-na-Gael delegates that the organization had become a mere 'cloak for Fenianism'. ${ }^{82}$ He was particularly concerned by the election of Patrick Egan as its president. Egan had sat on the Supreme Council of the IRB and served as treasurer to the Land League, when he was strongly suspected of having financed the Phoenix Park murders in I882. Jenkinson advised Spencer that Clan-na-Gael was likely to continue its support for the dynamite campaign in order 'to let Englishmen feel that there is a strong and desperate party of Force behind the constitutional agitators'. He believed that Parnell's public opposition to violence was based 'on grounds of expediency' and warned that if 'constitutional agitation' failed, then more violent action could be expected. ${ }^{8_{3}}$ Spencer was concerned by the ominous reports that he received concerning Irish republicanism. He was aware that the Fenian movement had never died out in Ireland but, upon resuming the viceroyalty in I882, he had expressed surprise at just how ubiquitous it appeared to be. He believed that 'treason' lay behind many of the most serious crimes of the Irish Land War and had therefore insisted that the offence of treason felony should come within the provisions of the Prevention of Crime Act. Over the following two years, Spencer had good reason to look out for rural secret societies in the West of Ireland and, in February 1884, warned Lord Granville that it 'must not be supposed that

\footnotetext{
${ }^{81}$ Journal (28, 3o July, 5 August 1885); Document ir. Carnarvon was familiar with Gavan Duffy's ideas, having met him on 22 July: CP, Add MS 60825, fo. 38. For the memorandum of his interview with Parnell, see Sir Andrew Hardinge, The Life of Henry Howard Molyneux Herbert, Fourth Earl of Carnarvon, I83I-I89o, 3 vols (London, I925), III, pp. I78-I8I.

${ }^{82}$ Jenkinson to Harcourt, I5 August I884: HP, Dep 2I. The British Government had several agents in America, including Henri Le Caron (Thomas Beach): see his Twenty-Five Years in the Secret Service: the recollections of a spy (London, I892).

${ }^{83}$ See Document 2; Jenkinson to Spencer, I7 December i884; Spencer to Edward Hamilton, 23 September I884: AP, Add MSS 77035, 7686o.
} 
organizations for crime and agitation though considerably weakened are altogether deprived of power' ${ }^{84}$

Fears over the strength of Fenianism in Ireland were compounded by the failure to eradicate dynamite attacks in Great Britain. Jenkinson's correspondence with Spencer in September I884 reflected the frustration that he felt while working for the Home Secretary in London. Jenkinson resented the rough treatment that he frequently received from Harcourt, whom he accused of behaving 'like a spoiled child' ${ }^{85}$ Harcourt believed that it was impossible to accommodate Irish nationalism, and confessed to Spencer that he saw 'no ray of light in the future. It is idle to conceal from ourselves', he added, 'that we do and can only hold the country by force. I am afraid that the via media of conciliation is impossible - there is no alternative between separation and coercion. ${ }^{96}$ He told Jenkinson that compromise was doomed to fail 'against the inveterate hatred of race', and warned that 'the strong arm' of British power was all that kept the Union together and that the time was 'fast coming when it must be used'. Such statements made Jenkinson 'almost despair of the future of Ireland'. To make matters worse, a rift between Clan-na-Gael and the IRB had apparently occurred in February I885 over the Supreme Council's opposition to the dynamite campaign, thus raising the danger that the minority of IRB members who favoured an 'active' policy might establish a separate 'violent party [...] composed of all the extreme men'. At the same time, Jenkinson wanted to take advantage of a fear that violence would harm the interests of the Irish in Britain and was confident that he could manipulate Fenian sentiment in the industrial cities of England.$^{87}$ In America, however, the prospects were not so bright. Jenkinson was severely shaken by the murder of one of his agents in New York and had learned that Clan-na-Gael was extending its operations to San Francisco, beyond the surveillance of his agents. 'Things look very ugly all round just now', Jenkinson informed Spencer in March, and a further dynamite explosion at the Admiralty almost ended his career at the Home Office. ${ }^{88}$

\footnotetext{
${ }^{84}$ Spencer to Granville, 28 January I883, 3 February I884; Spencer to Gladstone, 22 April I883: AP, Add MSS 76882, 76884, 76857. See also Document 3.

${ }^{8}$ Jenkinson to Courtney Boyle, I3 August I884: AP, Add MS 77034 .

${ }^{86}$ Harcourt to Spencer, 2I September I884: AP, Add MS 76933. Harcourt also complained 'in his old strain of the rotten and corrupt state of everything connected with the Irish Administration': Jenkinson to Spencer, i I November I884: AP, Add MS 77034.

${ }^{87}$ Jenkinson to Spencer, 2 October I884, 4 February, I3 March I885: AP, Add MSS 77034, 77036 .

${ }^{88}$ Jenkinson to Spencer, II March, 2r May 1885: AP, Add MS 77036; The Times, 24 April I885, p. 8; Jenkinson, 'Confidential memorandum', 22 June i885: CP, Add MS 6o829, fos $57-6$ I.
} 
While Jenkinson battled with the authorities in London, the economic condition of rural Ireland deteriorated and threatened to destabilize the country. This downturn had been accompanied - so the new Viceroy, Lord Carnarvon, told the Prime Minister, Lord Salisbury by a 'very serious growth in the power of the National League'. ${ }^{89}$ There were four main reasons why the influence and popularity of this organization had increased to the point where it had begun to challenge the authority of the state..$^{\circ}$ The first was economic: the agricultural depression that began in 1885 caused a fall in butter and stock prices that not only damaged the livelihood of small producers but also affected large-scale farmers and graziers. This, in turn, began to affect urban traders who were dependent upon the agricultural economy, and the financial position was further damaged when the Munster Bank failed on I4 July I885. ${ }^{91}$

The second reason for the growth of the National League was its success in gathering clerical support for its programme. Parnell had not been able to consolidate his political hold on Ireland without the support of the Roman Catholic Church. His abandonment of the quasi-revolutionary aims of the Land League in I882 had started a process of reconciliation with the Catholic hierarchy. Yet, in the early stages of the National League's development, few bishops had actively supported the organization. By the end of 1885 , however, the Irish police concluded that a clerical-nationalist alliance was the main reason for the League's rapid expansion. It was asserted that the great majority of active branches owed their success to 'the moral and educational force imparted to their work' by priests who relied upon 'the protection against the law which their clerical status' gave them..$^{92}$ During I882-I884, the Government had found an important ally in the Archbishop of Dublin, Edward McCabe, who disapproved of agrarian agitation and counselled restraint. Spencer regarded McCabe's death, in February I885, as a serious blow to his administration, particularly as his successor, William Walsh, was a firm supporter of the National League. ${ }^{93}$ It is therefore significant that,

\footnotetext{
${ }^{89}$ Carnarvon to Salisbury, 7 August 1885: CP, Add MS 6o825, fo. $5^{8 .}$

${ }^{90}$ See Donald E. Jordan, Jr, 'The Irish National League and the "unwritten law": rural protest and nation-building in Ireland, I882-189o', Past and Present, I58 (February I998), pp. I46-i I.

${ }^{91}$ See Journal (3o July $\left.\mathbf{1 8 8} 5\right)$.

$9^{2}$ 'Summary of Irish National League', Owen Slacke, SRM, 8 March I883, W.F. Forbes, SRM, 9 March I883: CSO RPs I883/6368, i883/6537 in INLP, carton 6; Slacke, DM, 'Progress of the National League', io January I886: CSO RP I886/647 in RP ı888/26523; Documents $4 \mathrm{I}$ and 42.

${ }^{93}$ Spencer to Hartington, I3 December I883; Spencer to Queen Victoria, I2 February I885: AP, Add MSS 76899, 76975 .
} 
after Fottrell had delivered an address in appreciation of the dead prelate, he ensured that Walsh was one of the first nationalist figures to be introduced to Sir Robert Hamilton. ${ }^{94}$

The National League also benefited from the imminence of a general election. The nationalists had already demonstrated their growing strength by winning four of the six Irish by-elections held in the winter of $1884^{-1885}$. By this time, the League had been transformed into a formidable electoral machine, and its membership expanded rapidly in this period..$^{95}$ The number of branches, which had stood at 8I 8 in July I885, grew to I26I by November, a five-fold increase since 1883 . Some of the urban branches existed solely for registration purposes but could be brought into working order whenever they were required..$^{96}$ The League also made dramatic progress in Ulster, but remained most popular in the former Land League strongholds of Munster and Connaught, where it presented the danger of another land war. Early in I885, it was reported that the League's expansion had provided a strong incentive 'for even the hitherto well disposed to join the winning side' and by the end of the year police officials concluded that 'the great mass of the people' had come under its influence. ${ }^{97}$

Finally, the National League's growth had been assisted by government policy. The Prevention of Crime Act was not directly employed against the National League because Spencer believed that its principal aims were constitutional. In February i884, he had commissioned a report for the Cabinet that clearly distinguished between the objectives of the National League and those of the Land League, which had been suppressed in i88I. The Irish AttorneyGeneral argued that, while the agitation for Irish self-government might be considered disloyal, in the absence of any threat of force, a campaign to abolish the Act of Union could not be regarded as treasonable and he warned that it would be 'a grave and unprecedented step' to prosecute its supporters. A subsequent decision

${ }^{94}$ Thomas J. Morrissey, William 7. Walsh: Archbishop of Dublin, I $844^{-192 I}$ (Dublin, 200o), p. 47; Journal (17 February 1885).

${ }_{95}$ Brian Walker (ed.), Parliamentary Election Results in Ireland, I80I-I922 (Dublin, I978), p. I29; Conor Cruise O'Brien, Parnell and His Party, I880-9o (Oxford, I957), pp. I26-I33.

${ }_{96}^{6}$ R.B. Beckerson, 'Progress of I.N. League during period from Ist January to 3 oth June I885', I5 July I885; Beckerson, 'Progress report of Irish National League, 3oth June to 3ist December 1885', I5 April I886: INLP, carton 6; Francis Cullen, DM, to IG, 6 January I886: INLP, carton 7 .

${ }^{97}$ Slacke, DM, to Jenkinson, I7 January I885: CSO RP I885/I279; Thomas Plunkett, DM, 'Progress of the National League: divisional reports for quarter ending 3 Ist December I885', 4 January I886: CSO, RP I886/576 in RP I888/26523. 
to prohibit police surveillance of branch meetings further loosened the Government's control over the League..$^{98}$

Perhaps the most important consequence of the failure to stem the growth of the National League was the resurgence of boycotting. Soon after taking office, Carnarvon concluded that 'silent and highly organized opposition' to the re-occupation of evicted farms was 'rapidly going beyond any legislative enactments which are within Government competences'. ${ }^{99}$ Hamilton therefore asked George Fottrell to intervene with the League's secretary, Timothy Harrington, to discourage the intimidation that frequently underpinned boycotting. On 24 September, Carnarvon consulted Fottrell, whom he judged 'a clever, shrewd man', and was advised that the problem stemmed from the critically low level to which agricultural prices had fallen. ${ }^{100}$ Carnarvon was assured by Edmund Dwyer Gray that the League's leaders were trying to bring boycotting under control. ${ }^{101}$ Nevertheless, recorded cases had increased almost fourfold since the Conservatives had taken office and, during the Cabinet meeting of 6 October, Carnarvon (so Lord Cranbrook recorded) painted a 'picture of Ireland that was in the gloomiest colours'. ${ }^{102}$ If, as has been asserted, British politicians in I885 and I886 were not concerned with influencing Irish audiences and could therefore afford to ignore 'the rising power and developing branch structure of the National League, the imminence of dark winter nights or of turbulent quarterly rent demands', it was not because they lacked evidence of their existence. ${ }^{103}$ In fact, Carnarvon took immediate steps to strengthen the RIC and appointed a new Inspector-General. Meanwhile, Hamilton hoped that his new-found contact with nationalist leaders might prevent a serious crisis and ensured that Fottrell kept him well briefed about Parnellite intentions.

A major concern for Dublin Castle was the reportedly close relationship that had developed between the National League and the IRB. When the League had been established in October i882, police officials had alleged that militant ex-Land Leaguers were planning

${ }^{98}$ Spencer to Hartington, I3 December I883; John Naish, 'Memorandum: suppression of the Nat. League', 4 February I884: AP, Add MSS 76898, 77318A. See also Document 42.

${ }^{99}$ Carnarvon to Salisbury, 7 August i885: CP, Add MS 60825, fo. 58 .

${ }^{100}$ See Journal (5 August 1885, 3 February 1886); Lord Carnarvon's diary, 24 September 1885: CP, Add MS 6o925; O’Day, Parnell, p. 97; and see Document I4.

${ }^{101}$ For memoranda of Carnarvon's meetings with Gray, see CP/TNA, PRO 30/6/67 (8), (22); Carnarvon to Sir Michael Hicks Beach, 23 September I885: SAP, D2455, PCG/78.

${ }^{102}$ Nancy E. Johnson, The Diary of Gathorne Hardy, later Lord Cranbrook, I866-92: political selections (Oxford, I98I), p. 576; Carnarvon's diary, 20 October I885: CP, Add MS 6o925.

${ }^{103}$ Cooke and Vincent, Governing Passion, p. I7. 
to use it to revive the land war and 'set the country ablaze again'. It was reported that the new organization embraced 'the entire scope of the Land League, the Fenian Society and socialist secret societies' ${ }^{104}$ Although no formal alliance existed between the two organizations, during the course of 1884 the police formed the impression that the IRB was using the National League as a vehicle for republicanism. In Cork, the Special Branch reported that republicans were 'willing to assist the National League in every way in their power' in the hope of 'getting men of some position and character' to join their organization. ${ }^{105}$ In Ulster, it was claimed that 'the more dangerous politicians of the League' favoured the establishment of IRB branches 'with the view of again playing the game of the old Land League when it becomes necessary to force on public opinion the necessity for a fresh change of the law in favour of the Nationalist or Separatist party'. By the beginning of I885, shopkeepers and large farmers who a few years beforehand were believed to have 'had their sympathies upon the side of law and order' were now regarded as 'openly disloyal', and it was reported that republican principles were being embraced 'by a more numerous and more intelligent and respectable class than hitherto'. Jenkinson concluded that Fenianism had effectively been 'absorbed by the National League' and reiterated his warning to the Cabinet that, behind their campaign to secure independence by constitutional means, Irish parliamentarians knew that they had 'secret organizations and a party of force at their backs' ${ }^{106}$

Furthermore, late in I885, the requirement to select candidates for the general election led the National League to establish branches in areas where agrarian outrages had once been common. In Mayo, it was reported that most of the county's sixty branches existed solely for the purpose of raising funds for arms. ${ }^{107}$ On I2 September, Jenkinson furnished Carnarvon with a report from his chief agent in Clan-naGael, who, upon visiting republican strongholds in north Kerry, was astonished at the recent change in republican attitudes and claimed

\footnotetext{
${ }^{104}$ Jenkinson to Spencer, 6 October I882: AP, Add MS 77031; Henry Blake, SRM to Hamilton, I6 December I882: CSO RP I882/46856; J.H. Davies, 26 January i883: ILL \& INL, carton 9 .

${ }^{105}$ DICS William Jacques to Butler, DM, 2 February I884; Andrew Reed, DM to Jenkinson, 4 December I884; DICS Robert Starkie to Plunkett, 28 November I884: CSO RP I885/1279; 'Memorandum explanatory of the aims and objects of the "Irish Republican Brotherhood" or "Fenian Society", September i89o: TNA, CO 904/ı6.

${ }^{106}$ DICS Samuel Waters to Jenkinson, I2 December i884; Slacke, DM to Jenkinson, I7 January i885; DICS Henry Bouchier to Slacke, DM, i2 December i884: CSO RP I885/1279; Jenkinson to Spencer, in November i884: AP, Add MS 77035. See also Document 8.

${ }^{107}$ J.H. Davies to Hamilton, 27 March I886: CSO RP I886/I8485; RIC Special Branch report, c. January I887: INLP, carton 7.
} 
that 'all but a very few extreme men' had now joined the National League and were ready to support home rule. ${ }^{108}$

Jenkinson was concerned that a 'recrudescence of dangerous Fenianism' might upset the government's tentative accommodation with mainstream nationalists. Dublin was thought to be home to one hundred 'Invincibles', who, Jenkinson claimed, might 'at any moment become active and dangerous' should 'the signal for "active" work' be given. He believed that the forthcoming general election would be a pivotal event, and warned the Home Secretary that, if Parnell failed to obtain some form of home rule by the end of the next parliamentary session, then the Government would face 'a repetition of what happened in I88I and I882'. ${ }^{109}$ As the fundraising activities of the National League of America gathered pace, Carnarvon received a lengthy report from Howard Vincent, the former CID Commissioner, who had recently toured Ireland. He claimed that Irish parliamentarians dreaded the violent influence of the 'Fenian exiles' in America but could not publicly repudiate them without losing their financial support. ${ }^{\text {11 }}$

On i7 October, Carnarvon consulted Hamilton, who had learned from Fottrell that Parnell was distributing National League funds to well-known republicans for the purpose of, as the Commissioner of the Dublin Metropolitan Police, David Harrel, put it, 'screwing the sympathies and support of the IRB and Fenian societies in Dublin' for the Parliamentary Party. Harrel suggested that some of this money would find its way to the 'bad lot' in Dublin, who, he believed, were 'being held in reserve for whatever may be needed', and warned Hamilton that 'the movements of the dangerous classes in Dublin at present closely resemble what occurred in $\mathrm{I} 88 \mathrm{I}-82 .{ }^{\mathrm{III}}$ Jenkinson, however, argued that such payments were a regular feature of Irish parliamentary elections, particularly those involving Parnell, and remained confident that the Irish leader would quell any violence prior to the election. Nevertheless, he reminded Hamilton that there was practically 'no difference now between a Nationalist and a Fenian. They both have the same object in view; and both would resort to extreme Revolutionary measures, if they thought it would be to their advantage to do so. ${ }^{{ }^{\prime \prime 2} 2}$ At the same time, Howard Vincent

${ }^{108}$ Jenkinson to Carnarvon, I2 September I885: CP/TNA, PRO 30/6/62 (27).

${ }^{109}$ Carnarvon's diary, 3 August I885: CP, Add MS 6og25; Jenkinson to Carnarvon, 25 July, 5 August i885: CP/TNA, PRO 30/6/62 (9), (I3); Document 12.

${ }^{110}$ Howard Vincent to Carnarvon, 25 September I885: CP/TNA, PRO 30/6/67 (9); Carnarvon's diary, I7 and 20 October I885: CP, Add MS 6o925.

${ }^{111}$ Document 18; Jenkinson to Carnarvon, io October I885: CP/TNA, PRO 30/6/62 (26); Harrel to Hamilton, I5 October I885: DMP, carton I.

${ }^{112}$ Jenkinson to Hamilton, I 6 October I885: DMP, carton I. For a study of this relationship, see M. J. Kelly, The Fenian Ideal and Irish Nationalism, I882-I9I6 (Woodbridge, 2006). 
assured Carnarvon that separatism was 'confined only to the most extreme \& violent section' of the nationalist movement and there was growing evidence of dissension within its ranks. ${ }^{\mathrm{II}}$ Members of Davitt's radical agrarian and social democratic wings of the movement already appeared to be pursuing independent objectives. Divisions between those who wished to democratize the leadership of the National League and secure a radical settlement of the land question, and the so-called National Conservatives who supported Parnell emerged at the annual commemoration of the Manchester Martyrs in Dublin, which was the largest and best organized of its kind since I867 and, as Harrel commented, 'a very significant index' of the current strength of the Fenian organization. ${ }^{114}$

The pro-home-rule sympathies of Hamilton and Jenkinson resonated with Lord Carnarvon. While in many ways an orthodox Tory, Carnarvon's preoccupation with the social and economic condition of Ireland marked him out from most of his Cabinet colleagues. Hamilton had once served on Carnarvon's commission on colonial defences and held a high opinion of his abilities. He soon found that he was permitted to vent his opinions on questions of policy as freely to Carnarvon as he had to Spencer, and, as Lord Ashbourne later observed, Hamilton's views 'had much weight' with the Viceroy. On welcoming Carnarvon to office, Hamilton stated his view that the Irish question remained 'the question of the day', upon the treatment of which depended 'not only the future of this country but grave imperial interests also'. ${ }^{.15}$

Carnarvon's outlook on Ireland was also influenced by Gavan Duffy, with whom he had talked and corresponded at some length. ${ }^{116} \mathrm{He}$ accepted that a return to 'the old methods of Government in Ireland' was impossible and had only accepted the viceroyalty on condition that coercion was to be abandoned. He was reassured by reports of his personal popularity in Ireland and he believed that the ministry might 'risk appealing to good feeling in order to govern under the ordinary law' until agricultural conditions improved and landlordtenant relations recovered. Carnarvon was also in tune with the views of Edward Jenkinson. Some time before taking office, Carnarvon had requested an interview with him and later fought hard to retain his

\footnotetext{
${ }^{113}$ Vincent to Carnarvon, 25 September i885: CP/TNA, PRO/30/6/67 (9).

${ }^{114}$ Harrel to Hamilton, 23 November I885: CSO RP I885/2235I.

${ }^{115}$ Hamilton to Spencer, I3 August 1885: AP, Add MS 77060; Lord Ashbourne's diary, 27 March I89o, repr. A.B. Cooke and A.P.W. Malcolmson (eds), The Ashbourne Papers, I869-19I3: a calendar of the papers of Edward Gibson, Ist Lord Ashbourne (Belfast, I974), p. 26; Hamilton to Carnarvon, 26 June i885: CP/TNA, PRO 30/6/56, fos I5-I6.

${ }^{116}$ O'Day, Parnell, pp. 50-5I; and see CP, Add MS 6o82I.
} 
troubled intelligence chief. ${ }^{117}$ Although he was aware that Jenkinson was unpopular with the authorities in London, Carnarvon persuaded the Home Secretary, Sir Richard Cross, that Jenkinson's continued presence in the capital was essential for 'the unity \& completeness' of police operations against Fenianism. He relied heavily on Jenkinson's ability to counter the security threat and wanted his operation in Great Britain to be maintained at the highest possible state of efficiency. Carnarvon understood that the apparent understanding between the Conservatives and the Irish nationalists could be quickly undermined by a resurgence of republican activity. ${ }^{118}$

During the second half of I885, Hamilton and Jenkinson supported Carnarvon's efforts to persuade the Cabinet to reach an accommodation with Parnell. Jenkinson was convinced that decisive action should be taken prior to the general election and produced an extensive survey of the current state of Ireland for Carnarvon on 26 September. He suggested that the devolution of power to a representative Irish parliament was the only way of achieving order in Ireland and creating a more durable political union with Great Britain. Over the next two months, he kept the Government informed about developments within republican circles in the United States and across the United Kingdom. ${ }^{\text {"19 }}$ The official memoranda prepared by Jenkinson and Hamilton clearly influenced Carnarvon. The Viceroy's reports to the Cabinet in early October reflected their viewpoint as he warned colleagues that Parnell's command over agrarian radicals and American 'extremists' looked increasingly uncertain. With landlords and tenants 'fatally estranged' and a large majority in Ireland set on a national parliament, he warned that present constitutional arrangements could not last indefinitely. And yet, Carnarvon's suggestion that a local parliament was the only viable alternative to crown colony government failed to convince his colleagues that constitutional reform was needed and, in the interests of party unity, he agreed not to press his views. ${ }^{120}$ Nevertheless, Hamilton remained convinced that Carnarvon could use his current

\footnotetext{
${ }^{117}$ Harrel to Carnarvon, I9 September 1885: CP/TNA, PRO 30/6/67 (Io); 'Lord Carnarvon's notes of his proposals to his colleagues before taking office': CP, Add MS 60823, fos I5-I6; Jenkinson to Spencer, 23 April I885: AP, Add MS 77036.

${ }^{118}$ Carnarvon to Cross, 5, I2, and 25July I885; Cross to Carnarvon, 6 July i 885: CP/TNA, PRO 3o/6/62 (I), (4), (8), (2); Carnarvon to Cross, 4 and 3 I August 1885: BL, Cross Papers, Add MS 51268, fos I47-I48, I50-I53.

${ }^{119}$ Documents 15 and $\mathbf{1 8}$; Jenkinson to Carnarvon, io October I885: CP/TNA, PRO $30 / 6 / 62(26)$.

${ }^{120}$ 'Memo. of important Cabinet on Tuesday 6 October 85': CP, Add MS 60823, fo. I7; Hardinge, Earl of Carnarvon, III, p. I93; Carnarvon's diary, 5 and 6 October I885: CP, Add MS 6o925.
} 
popularity within Ireland to at least promote the idea of selfgovernment. After discussing the matter with Fottrell, Hamilton presented his own analysis of the Irish situation and its possible remedies to Carnarvon on 3I October. This important document was later to influence the development of Gladstone's home rule scheme and, along with Jenkinson's paper of the previous month, presented the Conservatives with a forceful case for Irish home rule. ${ }^{121}$

The effort made by Hamilton and Jenkinson to influence political thinking on Ireland cannot be said to have been a concerted one. In fact, over the preceding three years relations between the two men had grown increasingly fraught. From the outset, Jenkinson's dynamic approach to his duties had brought him into frequent conflict with Hamilton, and their working relationship at Dublin Castle came to be seen as 'very anomalous'. Because Jenkinson's responsibilities were never clearly enough defined, Hamilton became frustrated by what he regarded as Jenkinson's inappropriately independent attitude and his refusal to acknowledge him as his superior. The then Chief Secretary was also perplexed by Jenkinson's habit of bypassing Hamilton on matters of policy and found him too independent of his own authority, complaining that he was expected to correspond with Jenkinson 'when it suits his pleasure, as if we were two members of the Government'. ${ }^{122}$ Trevelyan did not feel that Jenkinson was shrewd enough to decide when to consult Hamilton, who had begun to suspect that his colleague was creating an imperium in imperio in the Chief Secretary's Office. ${ }^{123}$ In fact, as Assistant Under-Secretary for Police and Crime, Jenkinson did have complete responsibility for these matters and effectively administered an autonomous department that reported directly to the viceroy. Whenever it did become necessary to consult the Under-Secretary, Jenkinson complained that Hamilton took 'every opportunity to assert in an offensive way his official superiority'. ${ }^{24}$

Spencer recognized that there was 'no real sympathy' between Jenkinson and Hamilton and concluded that both men displayed

\footnotetext{
${ }^{121}$ Journal (28 October 1885); Documents 13 and 20.

${ }^{122}$ Trevelyan to Spencer, I4 November 1882, 27 April, 21 December I883; Hamilton to Spencer, I6 October, 23 November 1882; Hamilton to Trevelyan, I3 November I882: AP, Add MSS 76950, 76955, 76959, 77058. Jenkinson claimed that Hamilton 'seems to forget that I have held high posts of great trust and responsibility in India, and have had much more experience in administration than he has': Jenkinson to Spencer, 2I October I883: AP, Add MS 77032.

${ }^{123}$ Trevelyan to Spencer, 2I December I883: AP, Add MS 76959. Jenkinson's unpopularity in London was put down by his detractors to his 'empire-building proclivities': see Bernard Porter, The Origins of the Vigilant State: the London Metropolitan Police Special Branch before the First World War (London, 1987), p. I84.

${ }^{124}$ Jenkinson to Boyle, 26 October, 5 December I882; Jenkinson to Spencer, 2I October I883: AP, Add MSS 77031, 77032.
} 
'faults of style and manner'. In spite of his efforts to regularize the relationship between the two men, matters did not improve. ${ }^{125}$ In July i884, Hamilton was incensed by Jenkinson's 'insane' attempt to implicate members of the Irish Parliamentary Party in the dynamite campaign through the use of a female agent provocateur. He questioned whether Jenkinson should continue in government service, and complained to Spencer that his colleague's attempts to 'establish a system of espionage such as exists or has existed in continental countries seems to me to be opposed to constitutional government' and was bound to lead to a 'confusion of matters political with matters criminal'. ${ }^{126}$ Spencer characteristically took a less serious view of the affair and so Hamilton persisted in his attempts to have Jenkinson removed from the Irish administration. Yet, when he suggested that the decline in crime in Ireland had rendered Jenkinson's position in Dublin redundant, he was opposed by the Home Secretary, who set aside his own differences with Jenkinson to dismiss the idea as a 'spiteful and mischievous' scheme 'to make Robert Hamilton monarch of all he surveys'. ${ }^{127}$

Nevertheless, Jenkinson never ceased to ruffle feathers at the Castle. Trevelyan disapproved of his brusqueness and tendency to place administrative efficiency above political considerations, taking action that often exacerbated Trevelyan's parliamentary difficulties and gave him 'a sense of uneasiness almost amounting to despair'. 'He seems so intent on keeping the peace that he considers nothing else', Trevelyan complained, and suggested that the administration was being driven 'in an arbitrary direction' by a man who appeared to have 'no notion of the higher political and moral aspects of affairs'. He criticized the haste with which Jenkinson often acted 'when it is a question of repression' and bewailed 'the immense unpopularity' he (Trevelyan) had thereby acquired 'from being a willing mouthpiece of what is stern and stiff in the policy of the Government'. Trevelyan found his capacity to defend controversial police actions limited by Jenkinson's reluctance to pass confidential information to the Irish Office, and complained that he was being made into 'a sort of Castlereagh against my own will'. ${ }^{128}$

\footnotetext{
${ }^{125}$ Spencer to Trevelyan, I6 November 1882, 22 December 1883; Trevelyan to Spencer, 22 December 1883: AP, Add MSS 76950, 76959.

${ }^{126}$ Hamilton to Spencer, I0, I2, and I8 July I884: AP, Add MS 77059; FF, I2 July 1884, p. 3. For an account of the affair, see Michael Davitt, The Fall of Feudalism in Ireland (Dublin, I904), pp. 438-44I.

${ }^{127}$ Spencer to Harcourt, 23 November i884; Harcourt to Spencer, 23 November 1884; Spencer to Hamilton, 25 November I884: AP, Add MSS 76933, 77059.

${ }^{128}$ Trevelyan to Spencer, 22 November 1882, I4, I9, and 20 April, 8 May I883: AP, Add MSS 7695 I, 76954,76955 .
} 


\section{Gladstone, the Liberal Party, and the Irish Question}

It is probable that Jenkinson's obliviousness to departmental protocol and parliamentary procedure emboldened him to broadcast his opinions in ways that more seasoned officials might never have considered. Frustrated by the Cabinet's indifference to the Irish question, Jenkinson took action that appeared to breach the custom that prevented permanent civil servants from actively engaging in politics. In early November, he secured Carnarvon's permission to have his memorandum of 26 September printed for the information of the Cabinet. ${ }^{129}$ Given the sensitive nature of the document, Carnarvon wanted tightly to restrict its circulation. There was, however, an apparent breakdown in communication and Jenkinson, rather than sending a single copy to the Prime Minister as he had been instructed, also prepared copies for Cross, Randolph Churchill, and, remarkably, for Spencer, Northbrook, and Lord Rosebery. Rosebery was the only Liberal politician to receive a copy of the memorandum before Carnarvon had chance to intervene, and yet Jenkinson's decision to send such a sensitive official document to former Liberal ministers at this critical time was significant. He clearly crossed the line that restrained permanent officials from giving privileged information to persons outside government, and Carnarvon quite understandably failed to comprehend how Jenkinson could have so completely misapprehended his intentions, given that the paper had been printed with the Viceroy's consent and would therefore be regarded as carrying official authority. ${ }^{130}$ Jenkinson explained that he had not foreseen any objection to his showing an expression of his personal views to interested members of the Opposition. ${ }^{131}$ His relationship with Spencer was already well established and, shortly before issuing the memorandum, he had spoken to Northbrook on the question of home rule.

Yet his decision to send a copy of the memorandum to Rosebery requires some explanation. Rosebery could hardly have been described as a specialist on the topic. As he himself had confessed in May I885, 'My practical knowledge of Ireland is almost nil'. ${ }^{132}$ But

\footnotetext{
${ }^{129}$ See Document 15.

${ }^{130}$ See Documents 21-23; Christy Campbell, Fenian Fire: the British Government plot to assassinate Queen Victoria (London, 2002), p. I77.

${ }^{1311}$ Jenkinson to Carnarvon, Io November I885: CP, PRO 30/6/62 (36); A.B. Cooke and John Vincent, Lord Carlingford's Journal: reflections of a Cabinet Minister I88I (Oxford, I97I), p. I39.

${ }^{\mathrm{r} 2}{ }^{2}$ Rosebery to Chamberlain, 20 May I885:JCP, JC5/6I/r. His time at the Home Office as parliamentary under-secretary for Scottish affairs had not coincided with Jenkinson's secondment there: Rosebery to Gladstone, 4 June I883: GP, Add MS 44288, fos I7I-I72.
} 
it is clear that Jenkinson wanted his paper to reach the highest levels of the Liberal Party, and so it is significant that he wrote to Rosebery at a time when the latter was in frequent conference with Gladstone. Rosebery visited Gladstone at Hawarden on 27 October, just four days before the Liberal leader received Parnell's proposed constitution for Ireland. On 6 November, the day after Rosebery received Jenkinson's paper, Gladstone again asked to discuss the Irish question with him. ${ }^{133}$ Although Rosebery had agreed to Carnarvon's request to keep an 'absolute and entire silence on the subject' of Jenkinson's paper, he had been greatly struck by the force of its argument. The following day, Gladstone arrived at Rosebery's country house, where he remained for the next three weeks and, while the evidence suggests that Rosebery kept his word, it is not unlikely that, in the course of his discussions with Gladstone at Dalmeny, he did convey some sense of the apparent urgency of the Irish situation to his party leader. ${ }^{134}$

Gladstone admitted to Rosebery that previous hostility between his ministry and the nationalists had left the Liberals 'in great ignorance of the interior mind of the Irish party' which, he claimed, had 'systematically confined itself to very general declarations'. ${ }^{135}$ And yet, Gladstone's stance on the home rule question developed rapidly during his time in Scotland. Shortly before departing, he had told Chamberlain that Ireland was likely to become 'the first \& overruling business' of domestic politics, ${ }^{136}$ and, immediately after conferring with Rosebery between Io and I3 November, he was ready to draft his two proposals for Irish self-government. Gladstone appears to have become convinced that the Irish question required a prompt and definitive settlement, and, after discussing Ireland with Rosebery on several more occasions between 16 and 26 November, he returned to Hawarden to await the results of the general election. On 4 December, the Liberal leader confessed to Spencer that he had 'Ireland on the brain' and was more than ever convinced that it would be 'the big subject' in the next parliament. ${ }^{137}$

As had been expected, the general election was a tactical triumph for Parnell, as home rule candidates won 86 of Ireland's io5 parliamentary seats. While Spencer characterized the result as 'dreadful', for Gladstone it represented 'the fixed desire of a nation, clearly and

\footnotetext{
${ }^{133}$ Rosebery to Gladstone, 6 November 1885: GP, Add MS 44288, fo. 265; Gladstone to Rosebery, 7 November i885, repr. GD, XI, p. 424. It should be noted that the first letter dealt exclusively with the disestablishment of the Church of Scotland.

${ }^{134}$ See Rosebery to Carnarvon, Io November i885: CP, PRO 30/6/62 (35); and p. 4I, n. I 64 below.

${ }^{135}$ Gladstone to Rosebery, I3 November i885: GP, Add MS 44288, fos 269-270.

${ }^{136}$ Gladstone to Chamberlain, 6 November 1885, repr. GD, XI, p. 423.

${ }^{137}$ Gladstone to Spencer, 4 December I885: AP, Add MS 76863 .
} 
constitutionally expressed ${ }^{\prime} \cdot{ }^{13}$ In the United Kingdom as a whole, the election again appeared to be a triumph for Parnell. The Liberals had gained 335 seats and the Conservatives 249, the difference between them being made up by the 86 Irish nationalists. The solid Liberal majority that Gladstone had regarded as indispensable for an 'equitable and mature consideration' of the home rule question had not materialized. Yet, while he contended that it was for the Government to deal with Parnell, Gladstone declared himself ready to support a fresh initiative towards Ireland and acknowledged that 'at such a supreme moment' he might have to take on the question himself. ${ }^{139}$

By this time, Edward Jenkinson's belief that home rule should be regarded as a potentially conservative measure was spreading within governing circles. On 9 December, Sir Henry Ponsonby informed the Queen that the idea that nationalist demands must now be either accommodated or strongly resisted had gained ground, but warned that the latter course could be expected to provoke 'a renewal of dynamite attempts at outrage'. He explained,

Mr. Jenkinson, who sees Irishmen of all descriptions, laments that some form of Irish Local Government was not granted two years ago. The best thing now he believes would be to give local powers to a Central Board on the lines of suggestions to be made by Mr. Parnell, with safeguards against exaggeration, as he thinks Mr. Parnell would then exert himself in the cause of law and order and would be the Conservative leader in the Irish Council. ${ }^{140}$

On I I December, Jenkinson, perhaps prompted by a suggestion in the Daily News that Gladstone now favoured Home Rule, decided to contact the Liberal leader directly. ${ }^{141}$ The two men had first met at the House of Commons in November I882, and, in praising the 'splendid service' that Jenkinson subsequently rendered in Dublin, Gladstone assured Spencer 'I am not at all surprised. He made on me the most decided as well as most favourable impression. ${ }^{{ }_{142}}$ Jenkinson was by now aware that the Conservatives were unlikely to find a satisfactory settlement to the Irish question. When, on 5 November, Jenkinson had discussed the contents of his secret memorandum with Lord Salisbury,

\footnotetext{
${ }^{138}$ Spencer to Gladstone, 2 December 1885; Gladstone to Rosebery, I3 November 1885: GP, Add MSS 44312, fos I98-20I, 44288, fos 269-270.

${ }^{139}$ Gladstone to Rosebery, I3 November I885: GP, Add MS 44288, fos 269-270; Gladstone to Spencer, 4 December I885: AP, Add MS 76863 .

${ }^{140}$ Sir Henry Ponsonby to Queen Victoria, 9 December 1885 , repr. G.E. Buckle (ed.), The Letters of Queen Victoria, Second Series, 3 vols (London, I928), III, pp. 709-7IO.

${ }^{141}$ Daily News, io December I885, p. 5 .

${ }^{142} G D, \mathrm{X}$, pp. 37I, 410; Gladstone to Spencer, I December I882, 27 February i883: AP, Add MSS 76856,76857 .
} 
the Prime Minister had appeared deeply pessimistic about Ireland and admitted that 'Home Rule could not come from the Conservatives'. ${ }^{143}$

In spite of his past indiscretions, Jenkinson knew that his position as a permanent official prevented him from informing Gladstone of the Prime Minister's views, although Salisbury had made no secret of them when he met Spencer at Sandringham in mid-November. ${ }^{144}$ Nevertheless, he did feel at liberty to supply Gladstone with his assessment of the Irish situation based upon what he believed to be happening 'behind the scenes both in Ireland and in America'. This correspondence is of considerable historical importance because it took place shortly before Gladstone brought the question of home rule to the forefront of British politics. Indeed, Jenkinson's letters and the debate they stimulated appear to have directly influenced Gladstone's thoughts and actions during the crucial last weeks of $1885 .{ }^{145}$

Upon leaving office, Gladstone had acknowledged that Parnell's anticipated success at the next general election would 'at once shift the centre of gravity in the relations between the two countries' and pose constitutional questions to which 'an adequate answer' would be required. ${ }^{14^{6}}$ In early August, Parnell had indicated to him that a wider measure of self-government than that considered in the spring was required, and he subsequently chided colleagues for underestimating the probable consequences of 'a serious dispute with the Irish nation'. Given that Gladstone had scant direct experience of Ireland yet expected the question to 'open [...] like a chasm under our feet', firsthand information about conditions there was invaluable to him. ${ }^{147} \mathrm{In}$ October, Spencer briefed Gladstone in terms that closely resembled those used by Hamilton and Jenkinson in their reports to Carnarvon. He advised him that Parnell had 'united on his side most of the leaders of outrage' but that they would 'hold their hand' until he had 'had a chance to see if he can carry his plans for Home Rule'. He added, 'great anxiety prevails as to whether Parnell can hold the extremists who are very impatient' and warned that unstable relations between landlords and tenants had created 'a very dangerous position', in

\footnotetext{
${ }^{143}$ Document 22.

${ }^{144}$ See Document 22.

${ }^{145}$ Jenkinson's correspondence with Gladstone was noted briefly by J.L. Hammond, and has been cited in more recent works by Colin Matthew, Roy Jenkins, Richard Shannon, and Christy Campbell. Nevertheless, the letters are not well known and for many years lay undiscovered in the archives of Macmillan in a collection of documents used by John Morley for his biography of Gladstone: M.R.D. Foot, 'A revealing new light on Gladstone', The Times, 6 November i97o, p. Io.

${ }^{146}$ Gladstone to Spencer, 30 June I885: AP, Add MS 76862.

${ }^{147}$ Katherine O'Shea to Gladstone, 5 August I885; Gladstone to Rosebery, ro September I885: GP, Add MSS 56446, fos 78-83, 44288, fos 242-244; Gladstone to Spencer, I5 September 1885: AP, Add MS 76863 .
} 
which it was clear that the Irish Government was 'powerless \& in the hands of the Natl. League'. Recent news from Dublin had led Spencer to believe that 'the moderate party' had been overruled and that boycotting would be 'carried on with renewed vigour'. ${ }^{14^{8}}$

By December, the situation appeared to have grown even more dangerous. In Ireland, the Constabulary confirmed that the Irish party now dominated political life in most parts of the country. The Inspector-General even paid tribute to the National League's control over its supporters during the general election, its officials having 'formed themselves into a police and watched and prevented the slightest misconduct on the part of their followers'. ${ }^{49}$ His subordinates in the south and west of Ireland were, however, more pessimistic about the influence of the League. One divisional magistrate characterized it as an 'open organization for the promotion of crime \& agitation', while another reported that the League was now so perfectly organized that the people yielded 'the most implicit obedience to it, even against their own individual interests'. It was characterized as a tyranny enforced by 'a secret organization' that had survived the suppression of the Land League and was now being revived. ${ }^{15^{\circ}}$

Jenkinson was therefore eager to impress upon Gladstone the growing influence of physical-force republicanism within Irish nationalist politics. He identified Clan-na-Gael as 'the main spring of the whole movement' because it controlled the flow of IrishAmerican money to Ireland and, by means of the Parliamentary Fund, could guide the policies of the Irish Parliamentary Party and the National League in Ireland. He warned Gladstone that the alliance between parliamentarians and Fenians was unlikely to last if Parnell's aspiration for Irish self-government was not met, and that violent agitation, political assassinations, and dynamite attacks might ensue. He therefore urged Gladstone to seize the opportunity offered by Parnell's overwhelming democratic mandate in Ireland to negotiate a settlement before the moderate majority of nationalists lost the capacity to restrain the 'violent' faction. If such an opportunity were to be squandered, he warned, the British Government would find itself 'face to face with open revolution'. Jenkinson assured Gladstone that allowing the Irish to regulate their internal affairs would not encourage separatism. Republicans, he predicted, would remain a

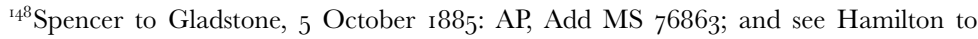
Carnarvon, 5 and 6 October I885: CP/TNA, PRO 30/6/57, fos 84-92.

${ }^{149}$ MCR (IG) for November 1885, Reed, Io December I885: CP/TNA, PRO 30/6/64 (38).

${ }^{150}$ MCR (SW) for November I885, Plunkett, DM, 4 December I885; MCR (W) for November 1885, John Byrne, DM, 4 December 1885, with minute from Carnarvon to Hamilton, II December I885: CSO RPs I885/23037, 24844.
} 
small and ineffective minority in an Irish parliament dominated by 'a strong Nationalist Conservative Party' that, supported by the Catholic Church, the professional classes, and many large-scale agriculturalists, could be trusted to protect the legitimate interests of the landed and Protestant minorities. Jenkinson suggested that a bipartisan approach to the question might be adopted once the legitimacy of home rule had been conceded. In all, he painted a stark picture of a country 'passing through a great revolution' and, in a passage to which Gladstone appears to have paid particularly close attention, he warned, 'if we do not grant Home Rule now we shall later on either have to agree to "Separation", or have to prevent Separation by force of arms'. ${ }^{51}$

Gladstone found Jenkinson's letter both unexpected and impressive. The arguments that it contained clashed with advice that he was then receiving from party colleagues, who believed that grassroots Liberal opinion was against 'coquetting with Parnell'. ${ }^{{ }^{22}}$ The former chief whip, Lord Richard Grosvenor, had warned him that any 'underground communications with the Irish party' might prove disastrous; and Rosebery contended that, when Parnell found himself unable to restrain his more radical supporters in the face of Tory indifference, he would be forced to bargain with the Liberals. He also warned Gladstone of the danger of proposing home rule without first securing the full support of the Liberal Party and British public opinion. A measure that was likely to cause such a 'mighty heave in the body politic', he argued, could only be carried 'by the full use of great leverage'. ${ }^{153}$ In spite of this advice, Gladstone informed Jenkinson that he agreed 'very emphatically' with the 'leading propositions' of his letter and was promptly reminded by Jenkinson that failure to settle the question 'on broad and liberal lines' risked 'heavy trouble in the future' ${ }^{154}$ Certainly, the mood around Gladstone already seemed dark. On I2 December, Edward Hamilton recorded, 'The Parliamentary and political situation is bad enough, but it is made still worse by the state in which Ireland is represented to be. According to all accounts that state was never worse.' In spite of there being little violent crime, it was reported that 'a complete reign of terror' existed in Ireland. 'The League is absolutely dominant', he recorded, 'and it seems that we may be within a reasonable distance of a general strike against rent. ${ }^{9}{ }^{155}$

\footnotetext{
${ }^{151}$ See Document 27.

${ }^{152}$ Gladstone to Hartington, I5 December 1885 , repr. $G D$, XI, p. 448.

${ }^{153}$ Grosvenor to Gladstone, I4 December I885; Rosebery to Gladstone, I2 December 1885: GP, Add MSS 56446, fos I82-I85, 44288, fos 279-284.

${ }^{154}$ Documents 28 and 29; $G D$, XI, p. 445.

${ }^{155}$ Edward Hamilton's diary, I2 December I885: EHP, Add MS 48642, fo. 48.
} 
Jenkinson's view of Ireland was echoed by another of Gladstone's correspondents. Also on i I December, James Bryce reported upon a growing feeling that things could not continue there in their present state. The performance of the Conservative Government in the wake of Parnell's electoral success had, he believed, 'given rise to a feeling of contempt for the authority of Parliament' that only a broad measure of self-government could overcome. Bryce, like Jenkinson, believed that most nationalists were not in favour of an Irish republic and he reported that 'the revolutionary party' enjoyed little support outside the larger towns. But he warned Gladstone that Parnell was not a free agent and that, in order to reach a definitive political solution, it was imperative that the Irish leader should state what he and his more extreme backers were prepared to accept. ${ }^{156}$ These warnings of incipient revolution clearly surprised Gladstone, who confessed to being 'somewhat stunned' by the abundance and diversity of recent communications on Ireland. Convinced that the dangers of the situation were 'too great, [and] time too precious, for the mere folding of arms', he promptly resumed contact with the nationalist camp through Katherine O'Shea. ${ }^{157}$

First-hand analyses of the Irish situation provided Gladstone with the information he would need if he was to convince British political opinion that home rule was now necessary. Jenkinson's letters to Gladstone had been private expressions of opinion but, with the writer's permission, Gladstone quickly circulated the intelligence to those of his colleagues who stood 'foremost in responsibility as to Ireland'. On i3 December, he hinted to Rosebery (superfluously in this case) that he now had reason to believe that 'very important permanent officers believe Home Rule is necessary'. ${ }^{15^{8}}$ Two days later, Hartington was requested to read and circulate Jenkinson's letters to Granville and Spencer, and did so, after first showing them to Harcourt and Northbrook. While both men were already aware of Jenkinson's opinions on home rule, Harcourt was particularly impressed by the danger of failing to act decisively. ${ }^{159}$ Although reluctant to commit himself to home rule at this point, he was, as Henry Labouchere

${ }^{156}$ James Bryce, 'Irish opinion on the Irish problem', in December 1885: GP, Add MS 44770 , fos $5^{-1} 4$.

${ }^{157}$ Gladstone to Granville, I8 December i885: GP, Add MS 56446, fos 193-195. See also Katherine O'Shea to Gladstone, Io and I5 December I885; Gladstone to Katherine O'Shea, I2, I6, I9, and 24 December I885, all repr. GD, XI, pp. 446, 449, 454, 46o-46I.

${ }^{15}{ }^{8}$ Gladstone to Rosebery, I3 December 1885 , repr. $G D$, XI, p. 447.

${ }^{159}$ Gladstone to Hartington, I5 December 1885, repr. GD, XI, p. 448; Northbrook to Spencer, I7 December I885, repr. RE, II, pp. 85-86; Hartington to Granville, I7 December I885, repr. Bernard Holland, The Life of Spencer Compton, Eighth Duke of Devonshire, 2 vols (London, I9I I), II, pp. 98-99; Hammond, Gladstone and the Irish Nation, p. 435. 
reported to Randolph Churchill, 'preoccupied with the thought that if nothing were done, dynamite would begin again'. ${ }^{160}$ But while the sense of urgency imparted by Jenkinson's forebodings galvanized some former ministers into action, those forebodings also stimulated resistance from others. Hartington, who felt starved of information about Gladstone's intentions, commented that, if the terms were as Jenkinson had set them out, it would be 'useless to think of stopping short of separation'. Gladstone's consequent warning that there was currently in Ireland 'a Parnell party and a separation or civil war party, and the question of which is to have the upper hand will have to be decided in a limited time' only served to increase Hartington's resistance to compromise. His assertion that the concession of home rule was tantamount to 'giving way to dynamite' was one that deserved an answer and Rosebery, who now accepted the case for home rule, countered that, while 'no prudent minister disregards dynamite', he should have 'sufficient moral courage not to avoid doing the right thing for fear he should be suspected of fearing dynamite'. ${ }^{.61}$

Hartington, however, was not alone in his opposition. Northbrook was surprised that Jenkinson had expressed the case for home rule more strongly to Gladstone than he had in his own conversations with him. After further discussing the question with Jenkinson on I7 December, Northbrook concluded that his cousin's confidence that a conservative majority would 'keep the extremists in check' in a future Irish parliament was misplaced. Northbrook argued that the concession of Irish self-government would immediately dissolve the temporary bond between republicans and home rulers on both sides of the Atlantic. An Irish parliament would, he told Spencer, quickly become 'a platform for further demands and lead either to separation, or to a fight to prevent it, and a fight for which our action would have strengthened our opponents'. This would present the British Government with the 'simply appalling' choice of accepting separation or revoking home rule and thus facing 'the consequences of having to govern Ireland absolutely', alternatives that Northbrook regarded as 'so detestable' that he found it 'very difficult to choose between them'. ${ }^{162}$

On 22 December, Spencer furnished Gladstone with his most recent letters from Jenkinson and Hamilton. Gladstone did not give

\footnotetext{
${ }^{160}$ Labouchere to Churchill, 23 December I885: RCHL I/Io. II99; and see Journal (3 January 1887).

${ }^{161}$ Hartington to Gladstone, I6 December I885: GP, Add MS 44148, fo. I64; Gladstone to Hartington, i7 December i885, repr. GD, XI, p. 45I; Rosebery to Spencer, 3 I December I885, repr. $R E$, II, pp. 96-97.

${ }^{162}$ Northbrook to Spencer, 16 December, ${ }_{1885}$, repr. $R E$, II, pp. 85-86 (incorrectly dated I7 December); and see Document 3 o.
} 
Jenkinson's advice on the tactical means of securing home rule as much weight as he had given to his warnings of its necessity, but he was intrigued to learn that Hamilton was also in favour of home rule. ${ }^{163}$ Although Gladstone considered the news of Hamilton's conversion to be 'most secret', he immediately used this information to persuade doubters such as Sir Henry James of the virtues of Irish self-government. On 24 December, he informed Rosebery that now both Hamilton and Jenkinson, the latter 'with dark anticipations otherwise', had 'both become Home Rulers' ${ }^{164}$ Notwithstanding the lukewarm reception accorded to Jenkinson's intelligence by some of his colleagues, Gladstone sought to use it to persuade the Conservatives that urgent action was required. An opportunity arose during a chance encounter with Arthur Balfour at the Duke of Westminster's Cheshire home, Eldon Hall, on 15 December. As Richard Shannon has pointed out, on the day previous to this meeting Gladstone had been informed by Frank Hill of the Daily News that Salisbury was preparing to make a significant concession to Parnell, provided that he could carry the Cabinet with him, and he received similar information from Canon Malcolm MacColl, who had recently spoken to the Prime Minister.

While this 'flyblown misinformation' may have provided Gladstone with sufficient confidence to confront Balfour directly, it was Jenkinson's disclosures about the current state of Ireland that provided him with his text. ${ }^{165}$ What struck Balfour most forcefully during his encounter with Gladstone was the latter's claim to be in possession of

information of an authentic kind - but not from Mr. Parnell - which caused him to believe that there was a power behind Mr. Parnell which, if not shortly satisfied by some substantial concession to the demands of the Irish Parliamentary party, would take the matter into its own hands and resort to violence and outrage in England for the purpose of enforcing its demands.

When a sceptical Balfour asked whether the government might expect 'to be blown up and stabbed if we do not grant Home Rule by the end of the next session', Gladstone replied that he understood 'that the time is shorter than that'. The puzzle over why Gladstone became convinced that Irish nationalism threatened a 'critical degree of violent action' in mid-December I885 can therefore be better

\footnotetext{
${ }^{163}$ Documents 33 and 34 .

${ }^{164}$ Askwith, Lord Fames of Hereford, pp. I58-159; Gladstone to Rosebery, 24 December I885, repr. $G D$, XI, p. 46r. Rosebery replied, 'I have known Jenkinson's opinion for months and it weighed greatly with me. But I had given my word of honour not to mention it': Rosebery to Gladstone, 26 December I885: GP, Add MS 44288, fos 289-29o.

${ }^{165}$ Shannon, Gladstone, p. 393; Andrew Roberts, Salisbury: Victorian titan (London, I999), p. 364 .
} 
understood in the light of the disclosures recently made to him by Edward Jenkinson. ${ }^{16}$

Some within the Fenian movement had long regarded Gladstonian reformism as the result of their efforts. ${ }^{167}$ The threat posed by republicans at this time, however, was not the only concern for Gladstone. He was also mindful of a warning that he had received from Harcourt that, if frustrated in their aims, the Irish party might withdraw en bloc from Westminster and establish a national convention in Dublin, thus making an orderly transition to devolved government impossible. This he considered to be the most formidable danger then facing the British Government, and one which brought 'into view very violent alternatives' ${ }^{168}$ In fact, the spectre of Irish secession had haunted Gladstone for some time and had fuelled his drive to establish central boards the previous spring. He also knew that, should Parnell lose his capacity to tame the revolutionary forces within his coalition, the resulting violence might delay the settlement of the Irish question for another generation. ${ }^{169}$ Herbert Gladstone, perhaps influenced by Jenkinson's letter to his father, hinted at this possibility in his statements to the press. On io December, Gladstone had remarked to his son that the Irish question 'ought for the highest reasons be settled at once'. Yet it is significant that Herbert's first letter on the subject, written on 4 December and published in The Times on 12 December, did not allude to any threat of violence in the event of home rule being withheld. Some days later, however, he had come to believe that the British public needed to be aroused to this danger by, as he later put it, 'a cold shower bath, rather than by the customary method of disorder and crime'. His subsequent statement to the National Press Agency, made on i6 December and printed in the Leeds Mercury and the Standard the following day, hinted that an outbreak of serious disorder in Ireland might undermine the Liberals' capacity to deliver home rule. ${ }^{170}$ Privately, Herbert accepted Jenkinson's view that Parnell was prepared to accept 'a reasonable basis' for home rule, but he was also concerned that the Irish leader might 'be forced by the Fenians to go on and make some "show for his money". The Pall

\footnotetext{
${ }^{166}$ Shannon, Gladstone, pp. $393^{-394}$; Balfour to Gladstone, I July 1886, printed in The Times, 5 July I886, p. Io.

${ }^{167}$ Oliver P. Rafferty, The Church, the State and the Fenian Threat I86I-75 (New York, I999), p. III.

${ }^{168}$ Matthew, Gladstone, p. 485 ; Northbrook to Spencer, i6 December I885: AP, Add MS 76918; Gladstone to Grosvenor, 7 January I886, repr. GD, XI, p. 475; Shannon, Gladstone, pp. 394-395.

${ }^{169}$ Gladstone to Spencer, 6 June I885: AP, Add MS 76862; and see Loughlin, Gladstone, Home Rule and the Ulster Question, pp. $4 \mathrm{I}^{-}-45$.

${ }^{170}$ Morley, Gladstone, III, p. 258; Herbert Gladstone to Lucy Cavendish, 31 December I885, repr. $G D$, XI, pp. $663-667$.
} 
Mall Gazette appeared, therefore, to carry an implicit message from Gladstone to Parnell when it stated that 'except in the event of any serious explosion in Ireland that would have the effect of exasperating the popular feeling in England against the Irish the country would in all probability endorse Mr. Gladstone's policy and give him an unmistakable mandate to carry it into law' ${ }^{171}$

At the same time, Gladstone's political strategy was undermined by the untimely appearance of the 'Hawarden Kite'. Both Northbrook and Rosebery were concerned that, by prematurely announcing his intentions, Gladstone might allow Parnell to manipulate the situation to his own advantage. Gladstone, however, used his contacts within the press to ascertain the private views of leading Parnellites and, with the support and encouragement of Spencer, persevered in his correspondence with Balfour. ${ }^{172}$ Emphasizing the fragile nature of the situation in Ireland 'of which every day's post', he claimed, brought him 'new testimony', Gladstone implored Balfour to treat the Irish question as one transcending party politics. ${ }^{173}$ Balfour's subsequent reports to Salisbury were, however, guided entirely by party considerations and merely weighed the tactical advantage of forcing Gladstone to bring his potentially divisive proposals before the Liberal Party. ${ }^{174}$ Gerald FitzGibbon had already warned Churchill against touching anything so 'red hot' as the national question, predicting that it would be far more advantageous if Gladstone or Parnell were forced to divide their respective followings by doing so. ${ }^{175}$ Salisbury, in turn, was contemptuous of Gladstone's appeal for a bipartisan approach to the Irish question, which he interpreted as 'a crude attempt to draw a veil of disinterested patriotism over a contemplated surrender to the Parnellite vote'. ${ }^{176}$ Nor did Gladstone's letters to Balfour cut any ice with the Cabinet: Cranbrook dismissed them as 'very Gladstonian and ambiguous \& pledging not even himself

${ }^{171}$ Edward Hamilton's diary, I5 December 1885: EHP, Add MS 48642, fo. 52; $P M G$, I7 December I885, p. 8.

${ }^{172}$ Document 3o. Rosebery to Gladstone, in December i885; Harold Frederic to Gladstone, i7 December i885: GP, Add MSS 44288, fos 276-278, 56446, fos i86-i87; Document 35; Gladstone to Spencer, 26 December I885: GP, Add MS 44312, fos 238239 .

${ }^{173}$ Gladstone to Balfour, 20 December 1885 , repr. $G D$, XI, p. 455.

${ }^{174}$ Balfour to Salisbury, 23 December 1885, repr. Robin Harcourt Williams (ed.), SalisburyBalfour Correspondence: letters exchanged between the third Marquess of Salisbury and his nephew Arthur Fames Balfour 1869-I892 (Hertfordshire Record Society, I988), p. I27; Morley, Gladstone, III, p. 259; Matthew, Gladstone, p. 483; Roberts, Salisbury, p. 366.

${ }^{175}$ See Roy Foster, 'To the Northern Counties station: Lord Randolph Churchill and the prelude to the orange card', in R.A.J. Hawkins and F.S.L. Lyons, Ireland Under the Union: varieties of tension (Oxford, 1980), p. 264; FitzGibbon to Churchill, 7 and 22 December I885: RCHL I/Io. II49, IIg6.

${ }^{176}$ Roberts, Salisbury, p. 366 . Salisbury claimed that Gladstone's 'hypocrisy makes me sick': Salisbury to Churchill, 24 December i885: RCHL I/ı. II99b. 
to anything real'. ${ }^{177}$ On 9 December, Salisbury informed Churchill that he no longer wished to continue with the pretence of accommodating Parnell. Instead, he proposed to meet parliament with the intention of seducing anti-home-rule Liberals away from Gladstone and declared, 'we can have nothing to do with any advances towards the Home Rulers. The latter case would be quite contrary to our convictions, and our pledges, and would be quite fatal to the cohesion of our party. ${ }^{177^{8}}$

It seemed that intelligent Conservative intuitions about Irish policy would always, in the end, be sacrificed to political opportunism. The encouragement offered by Salisbury to Carnarvon regarding the conciliation of Irish opinion seems to have been little more than a political manoeuvre. Once this tactic had, in the words of Salisbury's latest biographer, 'delivered the electoral goods', it was dispensed with. ${ }^{179}$ The Prime Minister's manipulation of the home rule issue was successful because both Parnell and Gladstone underestimated his 'narrow cynicism'. They were mesmerized by the apparent sincerity of Carnarvon's words and actions, and failed to comprehend that the single-minded pursuit of party interest would eventually supervene. ${ }^{180}$

Gladstone's failure to read Salisbury's intentions cost him precious time. His attempt to engage the Conservatives in constructive dialogue over Ireland dragged on into the first weeks of I886, time that might have been better spent preparing his own party for a new departure. ${ }^{181}$ At the same time, by instructing Irish electors in Great Britain to vote against Liberal candidates, Parnell inevitably turned many backbenchers against home rule, and alienated a large section of liberal public opinion, most crucially in Ulster. ${ }^{182}$ Parnell was not without his critics within nationalist circles: on I January I886, Michael Davitt predicted that home rule would not come in that year, the Irish having 'Parnell's stupid support of [the] Tories to thank for this'. With some prescience, he confided in his diary,

Had he [Parnell] stood neutral between both parties in English and Scotch elections Gladstone would have come back to power strong enough to give us a parliament. Popular feeling would not be as incensed against P[arnell] in Gt. Britain and the G.O.M. could have relied upon the rank \& file of his party.

${ }^{177}$ Johnson, Diary of Lord Cranbrook, p. 588.

${ }_{178}^{17}$ Roberts, Salisbury, p. 36 I.

${ }^{179}$ Foster, 'Northern Counties station', pp. 233-26r; Roberts, Salisbury, p. 360.

${ }^{180}$ Matthew, Gladstone, p. 478; Morley, Gladstone, III, pp. 260, 284; F.S.L. Lyons, Charles Stewart Parnell (London, 1977), p. 309.

${ }^{181}$ See Gladstone to Balfour, 5 January i886, repr. GD, XI, p. 473. The Balfour correspondence was alluded to by the Daily Telegraph on 28 June 1886 and Gladstone subsequently consented to its publication: see The Times, I July I886, p. 7.

${ }^{182}$ See Journal (9 December 1885). 
Davitt feared that the 'bragging of the Parnellites' over the defeat of Liberal candidates would 'destroy all chances' of home rule. When, Parnell subsequently 'boasted' to him of 'having balanced both parties so as to obtain the balance of power himself', Davitt replied that he had merely balanced the English members 'so evenly that he had probably united them against his dictation'. Further discussion of the subject, it was noted wryly, was 'evidently not relished' ${ }^{183}$ It is therefore clear that some of the strongest supporters of Irish independence believed that Parnell's much vaunted electoral success in 1885 was a Pyrrhic victory - a stunning tactical success but a costly strategic blunder.

Meanwhile, in Dublin, Carnarvon's attempt to promote an imaginative approach towards Ireland was floundering. For some time, Randolph Churchill had conducted his own Irish policy from the India Office: his engagement with the Catholic hierarchy on the education question being intended (so he candidly informed FitzGibbon) simply to 'mitigate or to postpone the Home Rule onslaught', in the hope that personal jealousies and 'Fenian intrigues' would meanwhile disrupt Parnell's national alliance. ${ }^{184}$ At Dublin Castle, some officials counselled caution. The Attorney-General, Hugh Holmes, and the Assistant Under-Secretary, William Kaye, deemed it unwise to go further than investing elected county bodies with the powers of grand juries, and Holmes warned Carnarvon that even this small concession might be interpreted as the first step towards an Irish parliament. Nevertheless, the Viceroy was increasingly concerned about the state of the country and discussions with Lord Ashbourne and the Chief Secretary, Sir William Hart Dyke, alerted him to the 'extreme danger $\&$ difficulty' of the situation. He knew that there was little chance of galvanizing his colleagues into action because Hart Dyke had already warned him of the 'slack mental condition' of the party regarding Ireland. 'They know \& understand nothing', he recorded; 'hate the subject - but hate still more a proposal to make any change'. ${ }^{\text {'85 }}$

After consulting Salisbury in late November, Carnarvon concluded that he had little option but to leave office. Nevertheless, he was persuaded to postpone his resignation so as to preserve the illusion of Cabinet unity and so made one last effort to persuade his colleagues to act. At two Cabinet conferences on ${ }_{4} 4$ and I5 December he advocated

\footnotetext{
${ }^{183}$ Davitt's diary, I and I7 January I886: TCD, Davitt Papers, MS 9545, DN/I8. Davitt had publicly criticized Parnell's manifesto at the Manchester Martyrs rally in Dublin: Ff, 23 November i885, p. 7.

${ }^{184}$ Churchill to FitzGibbon, I4 October 1885: RCHL I/8. 978, repr. Winston Churchill, Lord Randolph Churchill, 2 vols (London, I9o6), II, p. 4.

${ }^{185}$ Carnarvon, 'Conversation with Attorney Genl.', i6 November 1885; Sir William Kaye to Carnarvon, 20 November I885: CP/TNA, PRO 30/6/67 (24), (26). Carnarvon's diary, 6, 7, and 2i November, i I December i885: CP, Add MS 6o825.
} 
constitutional change in Ireland in terms that closely resembled the language employed by Jenkinson and Hamilton. He argued that it was important to recognize the claim of four-fifths of the Irish electorate for self-government and suggested that a committee be formed to draft an 'Irish constitution', just as Jenkinson had recently suggested to Gladstone.$^{186}$ But with only Ashbourne to support him, Carnarvon merely secured a vague assurance that the Cabinet would not wholly 'debar themselves' from establishing a parliamentary committee on Irish government, should circumstances allow. ${ }^{187}$ He returned to Dublin convinced that the Government would not announce a policy before parliament reconvened, thus leaving the Liberals to make the running on Ireland. The opinion recently offered to him by George Goschen - that Irish policy should consist 'in giving next to nothing \& coercing' - was, he believed, one now shared by most of the cabinet. ${ }^{188}$ With Irish interests now being equated with short-term party advantage, Carnarvon and Ashbourne had become isolated figures, the latter, Gladstone observed, 'all but cut in Dublin; eyed askance'. ${ }^{189}$

On I January I886, in Carnarvon's absence, the Cabinet unanimously rejected the idea of co-operating with the Liberals over home rule. As Salisbury's most recent biographer concedes, this decision was influenced solely by British imperial interests and sprang from the fear that Irish self-government would encourage separatism in other colonial possessions. With regard to the Irish people themselves, it is argued that 'their aspirations would not have rated on a par with what he [Salisbury] was increasingly coming to see as Britain's greatest contribution to civilisation and mankind, her Empire'. ${ }^{190}$

\section{Lord Spencer and Home Rule}

While the Liberals were aware that Carnarvon had lost all influence over events that were becoming increasingly dangerous, they preferred to leave the Irish question in the hands of the Conservatives. Nevertheless, the appearance of the 'Hawarden Kite' renewed hope

\footnotetext{
${ }^{186}$ Carnarvon's diary, I2 and I3 December I885: CP, Add MS 60825; Document 26. Hamilton's memorandum (Document 2o) was also printed for the use of the Cabinet.

${ }^{187}$ Roberts, Salisbury, p. 362 . Carnarvon's desire for conciliation was signalled in an editorial in the Dublin Daily Express on I9 December 1885: see FF, 21 December 1885, p. 4 .

${ }^{188}$ Carnarvon's diary, I4 and I5 December, I885: CP, Add MS 60825.

${ }^{189}$ Gladstone to Granville, 22 December I885, repr. GD, XI, p. 457.

${ }^{190}$ Roberts, Salisbury, p. 370.
} 
in Dublin that a satisfactory solution might be found and, as the result of the general election became known, Hamilton impressed upon Spencer the urgent need for a significant measure of selfgovernment. ${ }^{191}$ The development of Spencer's thinking on this question was a highly important element of the first home rule crisis but is one that has received relatively little attention from historians. Without the support of the former viceroy, whom John Morley considered to have 'a force of moral authority in an Irish crisis that was unique' and whose opinion on Irish questions was 'hardly second in weight to Mr. Gladstone himself', the home rule bill might not have emerged. Though Spencer was not generally regarded as an innovative politician, his reputation for disinterested and practical action and extensive experience of Ireland lent considerable weight to his views. Northbrook informed him that his position on home rule 'was the most important of that of any Englishman almost if not altogether' and, according to Morley, he exerted 'an influence over Liberal opinion without which Mr. Gladstone himself could hardly have gone on'. ${ }^{192}$

Jenkinson's earliest efforts to persuade Spencer to consider home rule had been hampered because, although the viceroy regarded him as 'a liberal broad-minded man', he lacked faith in his political judgment. While Spencer thought Jenkinson possessed ability, energy, and personal integrity, he had frequently remarked upon his lack of 'constitutional instinct or knowledge' and 'inattention to Parliamentary considerations' during his time in office. ${ }^{193}$ Yet Jenkinson retained a strong sense of loyalty towards Spencer and continued, while in opposition, to furnish him with his assessments of the political situation in Ireland and America. Hamilton was also eager to keep Spencer informed, but was alert to the sensitivity of communicating with his former chief at what he considered a 'very critical' time for the Government. He confessed to 'a curious feeling that in writing to you I should have to consider whether there is anything I should not say, having so long been accustomed to pour out my mind to you'. Jenkinson, however, was concerned that the intransigent attitude towards Ireland displayed by Chamberlain and Hartington was giving 'strength \& encouragement to the extremists'. In September I885, he exhibited his customary obliviousness to constitutional procedure by offering to meet Spencer in order to pass on 'a great deal of interesting

\footnotetext{
${ }^{191}$ See Documents 24, 32, and 37 .

${ }^{192}$ Morley, Gladstone, III, p. 26I; Morley, Recollections, I, pp. 220-22I; Document 30.

${ }^{193}$ Spencer to Gladstone, 22 April I883: Spencer to Harcourt, 2 August 1882, 7 March I884; Spencer to Trevelyan, 26 July, I9 November I882, 3 November i883: AP, Add MSS 76857, 76929, 76947, 76951, 76959.
} 
information' and warned him that Britain 'must decide upon one of two courses in Ireland. The present situation cannot last long. Everything is in a most critical \& ticklish state. ${ }^{{ }^{194}}$

Spencer dutifully passed on what he learned from Dublin Castle that autumn to Gladstone, who was to regret not having consulted the former viceroy prior to setting down his home rule proposals in mid-November. Nevertheless, he was subsequently to lean heavily upon the support and advice of Spencer, who cancelled a plan to spend the winter in India in order to be at Gladstone's disposal. But while Spencer confessed that he had no proposals to make at that stage, his views on Ireland were quietly evolving. ${ }^{195}$ During his first term as viceroy in I868-1872, he had become aware of the limitations of Castle government and had once declared, 'I shall soon become a Home Ruler, but for England \& Scotland as well as Ireland for if some improvement is not made local questions will be constantly sacrificed. ${ }^{196}$ And yet, during his second term, Spencer could not be convinced that Ireland was sufficiently stable to permit any but the most limited measures of local self-government. After leaving office, however, his views began to change. On I6 August i885, Spencer furnished Lord Lansdowne with a lengthy analysis of the political state of Ireland. Lansdowne, the owner of a large estate in County Kerry, was deeply hostile to home rule. Free from the shackles of office, however, Spencer at least felt able to consider this prospect. He was convinced that the understanding between Parnell and the Conservatives would soon collapse and he wanted the Liberals to consider some remedy, short of home rule, that might undermine Parnell's appeal to the Irish electorate. He suggested that a wide measure of local government, which stopped short of establishing a central authority, coupled with reforms to Irish administration and university education, might still win back middle-class Catholics to the Liberal cause. If this was to fail, then Spencer reluctantly conceded that an experiment in 'Federal Government with Home Rule' might be unavoidable. ${ }^{197}$

In early December, Spencer learned from Granville that a significant measure of Irish self-government was under consideration, and so travelled to Hawarden where he was shown Gladstone's plans. 'We have had tremendous talks', he told Lady Spencer, but admitted

\footnotetext{
${ }^{194}$ Jenkinson to Spencer, 6 and 12 August, 23 September 1885; Hamilton to Spencer, I3 and 30 August, I5 and 21 October I885: AP, Add MSS 77036, 7706o.

${ }^{195}$ Spencer to Gladstone, 2 December I885, repr. RE, II, pp. 80-8I.

${ }^{196}$ Spencer to T.H. Burke, I9 July I87r: NAI, Thomas Henry Burke Papers, box 3.

${ }^{197}$ Spencer to Landsdowne, I6 August I885, repr. $R E$, II, pp. 70-74.
} 
that he dreaded 'the political prospect more than ever'. ${ }^{9}{ }^{19}$ Spencer was greatly perturbed when, following Herbert Gladstone's conversations with the press, it was reported in the Pall Mall Gazette that he was 'practically convinced' that home rule was now unavoidable. He quickly denied the story but confessed to being 'in a most anxious state' about what line to take on the question. He informed Hartington that he was 'hopeless as to moderate measures', yet could not see his way 'over the difficulties of a bigger one'. Perhaps sensing that Spencer was, as he had privately confessed to being, 'much impressed and oppressed by the gravity of the position', Jenkinson and Hamilton each attempted to stiffen his resolve. ${ }^{199}$ Jenkinson had learned from Northbrook that his recent letters to Gladstone had been shown to Spencer and, like Hamilton, he alerted him of the danger of turning the question into a party issue. Each man encouraged the incorporation of all shades of 'constitutionalist' opinion into a public discussion of home rule. Their eagerness for a bipartisan approach to the political crisis in Ireland mirrored that of Gladstone, who simultaneously advised Hartington that 'its becoming a party question would be a great national calamity'. ${ }^{200}$

While Spencer withheld his judgment at this point, he did acknowledge that the events of the previous six months had entirely changed the political landscape and was prepared to declare himself 'dead against simple oppression'. On i7 December, he confided to his private secretary, 'our old methods are hopeless and useless' and the idea that any government might have resort to them made him 'despair of the future'. He confessed, 'I have always been smothering a feeling that some Home Rule would have to be given, but I feel that I have nothing left to smother it with.' It was at this point that Spencer wrote to Hamilton to express this change of heart and subsequently learned of the Under-Secretary's views on the subject. Yet, notwithstanding his private feelings on the question, Spencer was still unwilling to commit himself to home rule and insisted to Gladstone that the question 'must remain a mere matter of speculation'. ${ }^{201} \mathrm{He}$ first needed to satisfy himself that Irish self-government would not encourage separatism. 'I cannot help thinking', he told Granville, 'that a great deal of the outcry arises from fear of Separation. If that were

\footnotetext{
${ }^{198}$ Spencer to Gladstone, 5 December I885: GP, Add MS 44312, fo. 204; Spencer to Lady Spencer, 8 December 1885 , repr. $R E$, II, pp. 8I-82.

${ }^{199}$ Jenkins, Gladstone, p. 527; Spencer to Gladstone, I8 December I885: GP, Add MS 44312, fos 205-208; $P M G$, I7, I8 December I885, p. 8. Spencer to Courtney Boyle, i7 December I885; Spencer to Hartington, 20 December I885, both repr. RE, II, pp. 84, 87 .

${ }^{200}$ Documents 3I and 32; Gladstone to Hartington, 20 December 1885 , repr. GD, XI, p. 456 .

${ }^{201}$ Spencer to Courtney Boyle, i7 December I885, repr. RE, II, p. 84; Document 33.
} 
shown to be impossible, moderate views might prevail.' Jenkinson therefore tried to persuade Spencer that, under home rule, Parnell would still be able to prevent republicans from exerting 'a dominating influence in Ireland'. He argued that British statesmen had to trust that the Irish people would act on 'principles of commonsense' and reject separatism. Spencer believed that the Catholic Church was a very important element in the development of Irish public opinion and he was not convinced that the Catholic bishops would provide a bulwark against separatism. While he accepted that their 'present inclinations' were against separation, he also believed that the parish priests were 'unduly influenced by public opinion' and might therefore be expected to side with whichever political faction proved strongest. ${ }^{202}$

Having carefully discussed the issues of policing, land reform, and taxation with Campbell-Bannerman at Althorp, Spencer spent Christmas Day setting down his views on the implications of Irish home rule for Gladstone. He was inclined to agree with Jenkinson and Gladstone that 'absolute separation' was neither desired by the large majority of home rulers nor would it be 'tolerated' by British public opinion. At the same time, he was concerned that, in disrupting the system of Irish administration, and simultaneously alienating the propertied classes, the British Government would provide 'hostile' nationalists with 'a new \& better basis for agitation'. Home rule could only be justified, Spencer believed, if it could be confidently asserted that popular support for a moderate party was strong enough to prevent republicans from ever dominating an Irish legislature. Nevertheless, Spencer's mind was virtually made up, and on 27 December he advised Hartington that he thought the time for fighting home rule had passed, and that 'the sooner one takes the horrible plunge the better before fresh lives are lost and much more disaster is heaped on miserable Ireland'. ${ }^{203}$

Having reluctantly accepted the case for home rule, Spencer soon became frustrated by Gladstone's refusal to discuss the question openly with his colleagues. The Liberal leader, perhaps mindful of Jenkinson's recent correspondence, was concerned by the immediate threat of disorder in Ireland and its implications for home rule: 'what I feel apprehensive about', Gladstone told Spencer on 28 December, 'is the preliminary question shall we have a state of legality in Ireland to start from?' Arguing that this was something only the Government could know, he postponed further action until parliament reconvened and instead continued to press the Conservatives to take 'a strong and early

\footnotetext{
${ }^{202}$ Spencer to Granville, 29 December i885, repr. $R E$, II, p. 92; Documents 3I and 33 .

${ }^{203}$ Campbell-Bannerman to Spencer, 27 December I885; Spencer to Hartington, 27 December i885, both repr. RE, II, pp. 90-9I; Document 36.
} 
decision of the Irish question'. In the meantime, Gladstone adopted a strategy of proceeding towards home rule by stages in order to draw his colleagues into the process. He was satisfied that, by merely raising the question with his most trusted advisors, he had set in motion a 'slow fermentation of minds' that would convince his party of the necessity of the policy. ${ }^{204}$ Spencer therefore cautioned Gladstone that some leading Liberals were not open to persuasion on this matter. Having discussed the Irish question at length with Hartington at Althorp during 30 and 3I December, Spencer informed Gladstone that his guest was very unlikely to fall in with a large measure of home rule and believed, as Hartington himself put it, that the policy 'would utterly smash up the party'. ${ }^{205}$ Yet Gladstone remained averse to further consultation while the Conservatives remained in power, a policy that Rosebery claimed was leading to 'open revolt' ${ }^{206}$ He did, however, provide Granville and Spencer with a lengthy analysis of the situation on 26 December, and went into the details of possible lines of action four days later. Perhaps with Jenkinson's recent warnings in mind, Gladstone informed Spencer that, while he thought an instant decision on home rule was unnecessary, he did consider 'the faults \& dangers of abstention greater than those of a more decided course'. ${ }^{207}$

Meanwhile, Spencer's own discussions with his colleagues had created the unhelpful impression that, while he saw the offer of home rule as inevitable, he did not believe that the policy would succeed. Both Northbrook and Campbell-Bannerman therefore tried to dissuade Spencer from declaring his hand, fearing that it would only strengthen Parnell's position and thus increase the difficulty of governing Ireland. They thought that if Spencer did not (as Northbrook believed) 'look upon home rule as a good thing in itself, but only as the least of two bad alternatives', and was unable to guarantee that it would not be used as a stepping stone to independence, he ought

\footnotetext{
${ }^{204}$ Document 39; Gladstone to Balfour, 2 and 23 December I885, repr. GD, XI, pp. 455, 459; Matthew, Gladstone, p. 489; Gladstone to Granville, 9 December i885: GP, Add MS 56446 , fos I68-i69.

${ }^{205}$ Spencer to Gladstone, 3 I December i885: GP, Add MS 44312, fos 245-246; Gladstone to Hartington, 2 January I886, repr. GD, XI, pp. 47I-472; Spencer to Granville, $3^{I}$ December I885, repr. RE, II, p. 96; Hartington to Granville, i7 December I885, repr. Holland, Spencer Compton, pp. 98-99.

${ }^{206}$ Granville to Spencer, 27 December 1885 , repr. RE, II, pp. 9I-92. Gladstone to Granville, 28 December 1885; Spencer to Gladstone, 29 December 1885: GP, Add MSS 56445, fos I38-I39, 44312, fos 242-244; Gladstone to Granville, 3i December I885, repr. GD, XI, p. 469; Rosebery to Spencer, 3I December 1885, repr. RE, II, pp. 96-97.

${ }^{207}$ Gladstone to Granville, 26 December 1885 , repr. $G D$, XI, pp. $462-463$. Gladstone to Spencer, 26 December 1885; Granville to Spencer, 28 December 1885, both repr. $R E$, II, pp. 9o, 92. Gladstone to Spencer, 30 December 1885 , repr. GD, XI, p. 467.
} 
to withhold his endorsement. ${ }^{208}$ In fact, Spencer questioned whether a general declaration in its favour ought to be made before a detailed scheme had been developed, and reported to Gladstone, 'I confess that I look with dismay at what may occur in Ireland, if Parnell is backed by you in a demand for Home Rule: without a measure being carried at once.' Spencer therefore maintained his public silence and came away from a long meeting with Gladstone, Granville, and Chamberlain in London on I2 January convinced that 'nothing will be said or done in favour of Home Rule'. ${ }^{209}$ It was not until the Liberals returned to power in early February that Spencer made what was regarded as the most significant endorsement of Gladstone's policy. As Edward Hamilton recorded,

The predominance \& urgency of the Irish question have made Lord Spencer a most important man. His concurrence in Mr. G's views placing him, as regards Ireland, among the most influential of men. He will do more to soothe apprehensions than any one else; \& from the peculiar circumstances he is gaining a great position for himself. ${ }^{210}$

This view was echoed by the new Chief Secretary, John Morley, who later recalled that the 'shock of Spencer's conversion was severe, both social and political', because it gave 'driving point to general arguments for Home Rule. Without his earnest adhesion to revolutionary change in the principles of Irish government, the attempt would have been useless from the start and nobody was more alive to this than Mr. Gladstone himself..$^{21}$

Before Spencer made his views known, however, Hamilton had assured Fottrell in the strictest confidence that Lord Spencer 'would be sound on the Irish question'. By this time, Fottrell was actively circulating information about the various positions then being taken on the question by leading politicians. While John Morley later denied direct involvement in the home rule question prior to his statement to the Commons on 7 January I886, he was in regular contact with Fottrell throughout December and later recorded that 'signals and intimations were not wholly wanting from the Irish camp' on the matter at that time. ${ }^{212}$ Morley was trying to hold the Liberals

\footnotetext{
${ }^{208}$ Spencer to Granville, 29 and 3 I December i885; Spencer to Rosebery, 30 December I885; Hartington to Spencer, 3 January I886; Northbrook to Spencer, 7 January I886, all repr. $R E$, II, pp. 92-94, 96-гоo.

${ }^{209}$ Spencer to Gladstone, 8 January I886; Spencer to Lady Spencer, I2 January I886, both repr. $R E, \mathrm{II}, \mathrm{pp}$. IOO-IO2.

${ }^{210}$ Edward Hamilton's diary, 7 February I886: EHP, Add MS 48643, fo. 3 .

${ }^{211}$ Morley, Recollections, I, p. 219.

${ }^{212}$ See Journal (4, 27 January I886); Morley, Gladstone, III, pp. 296, 274. Morley did, however, speak in favour of home rule on 2I December 1885.
} 
together over Ireland and promised Chamberlain that he would pass on whatever he learned from Fottrell, while conceding that 'as we all know, all depends on Parnell, and he keeps his own counsel'. ${ }^{213}$

At the end of the year, Morley asked Fottrell to travel to Birmingham to try to persuade Chamberlain to support the idea of an Irish parliament. Fottrell had maintained contact with Chamberlain during the autumn and had been dismayed by the latter's anti-home-rule speech at Warrington on 8 September. He refused, however, to believe that Chamberlain was set against a separate legislature for Ireland until an exchange of letters confirmed that his former collaborator remained committed to the central board scheme. ${ }^{214}$ Chamberlain maintained that he wanted Ireland to have 'the widest possible measure of local government consistent with the security and integrity of the Empire', but did not believe, as he told Morley, in the viability of 'anything between my scheme of National Councils \& absolute separation'. He blamed the unreasonable and impractical demands of the Nationalists for the abandonment of his own scheme. 'A substantial good', he informed one of them, 'is therefore abandoned for an illusory gain, the shadow is once more preferred to the substance'. ${ }^{215}$

Like Rosebery, Chamberlain did not believe that Parnell could secure home rule from the Conservatives and would therefore have to moderate his demands and approach the Liberals. To negotiate with Parnell at that point, he insisted, ran the risk of providing Salisbury with an opportunity to dissolve parliament and call an election on the question of home rule. Chamberlain set out his position on the question to Sir Edward Russell of the Liverpool Daily Post,

My own policy would be to say to Parnell 'We offered you the utmost that we could conscientiously give, or that we could expect to carry. At the time you approved \& promised cooperation: afterwards you changed your mind believing that you could obtain more from the Tories. You threw your whole weight against us in the election, and you prevented us from obtaining the majority which would alone enable us to deal with the matter with any hope of success. You must lie on the bed you have made; you must go to your new friends and see what they will do for you, and we shall wait for the result of your communications'. ${ }^{216}$

Fottrell's efforts to temper Chamberlain's opposition to home rule had been approved by Hamilton and were common knowledge in nationalist circles. The day before their meeting, Timothy Healy

\footnotetext{
${ }^{213}$ Morley to Chamberlain, 24 December 1885:JCP, JC $5 / 54 / 670$.

${ }^{214}$ Journal (II September, 5 October I885); Documents 16 and 17.

${ }^{215}$ Chamberlain to Morley, 4 December I885:JCP, JC5/54/669; Chamberlain to George

F. Mulqueeny, 6 December I885: NLI, MS 5752, fos 222-229.

${ }^{216}$ Chamberlain to Sir Edward Russell, ${ }_{4}$ December 1885: JCP, JC5/62/24.
} 
commented to Henry Labouchere, 'I don't think F can physic C's disease'. ${ }^{217}$ Indeed, such doubts were well founded and Fottrell's talks with Chamberlain had only a temporary effect. Having, in Morley's words, 'kept straight for about a week' after the interview, Chamberlain soon 'relapsed into his sulks'. On 2I January, Chamberlain warned Spencer that recent speeches by Parnell had convinced him that the Irish leader's 'demand is for Legislative Independence as a step to complete Separation'. And on 4 February, Chamberlain informed Morley that, since defining his own plans for Irish self-government the previous summer, he had not altered his opinion 'in the slightest degree'. ${ }^{218}$

\section{The Conservatives and 'Coercion'}

In Dublin, Hamilton longed for a political initiative that might alleviate pressure on the Irish administration. On I4 January, Anthony Mundella informed Spencer of his 'long confidential interviews' with Hamilton, Davitt, and other nationalists. He concluded that the Irish Government now excited 'universal derision' and that the country had 'never been in so deplorable a condition'. Mundella anticipated a return to coercion and had warned Davitt that 'John Bull might be easily roused to put down [the] present state of things in Ireland "by the bayonet!"' Yet Hamilton's response to this - that "wild and bloody revenge' would ensue - would do little to deter the Conservatives from seeking a showdown with the nationalists. ${ }^{219}$

It should be said that the picture presented to the British Government by the Irish authorities at this time was unclear. The RIC Inspector-General, Andrew Reed, informed Dublin Castle that the anticipated breakdown of law and order in rural areas had not materialized and he reported that National League branches were largely 'on their good behaviour'. With the exception of small parts of country where 'moonlighters' were active, Reed asserted that no 'general conspiracy' against the payment of rent existed and predicted that most tenants would pay if abatements were granted. ${ }^{220}$ Hamilton, however, interpreted the latest police reports differently and advised

\footnotetext{
${ }^{217}$ Healy to Labouchere, 30 December 1885, repr. Algar Thorold, The Life of Henry Labouchere (London, 1913), p. 275.

${ }^{218}$ Journal (27 January 1886); Chamberlain to Spencer, 2I January I886, repr. $R E$, II, p. I03; Chamberlain to Morley, 4 February I886: JCP, JC5/54/685.

${ }^{219}$ Mundella to Spencer, I4January I886, repr. RE, II, pp. IO2-IO3. Mundella also assured Davitt that Gladstone was 'resolved to grant H.R. when he can safely do so': Davitt's diary, ıо January I886: TCD MS 9545/ı8.

${ }^{220}$ MCRs (IG) for November and December I885 and January I886: CP/TNA, PRO 30/6/64 (38), CSO RPs i886/2395, I886/669I.
} 
Carnarvon that he hardly took 'so sanguine a view of the state of the country' as Reed. He forwarded a recent report from the Western Division, which stated that lawlessness was increasing as the IRB 'acquired new life' and that the authority of the National League was now being maintained 'by terrorism'. It was anticipated that 'atrocious crimes' would be committed by agrarian secret societies, whose members were now 'beyond the restraining influences of religion'. Reports from other parts of the country were equally worrying. In the midlands, it was reported that the League had fallen under the influence of republicans and that any form of local government was liable to fall 'entirely under Fenian direction'. In the south-east, the National League was reported to have 'assumed a position of authority which has practically superseded the Government of the country' and was so ubiquitous that it would be 'very difficult to put down'. ${ }^{221}$ On I2 January, Hamilton reported that the latest reports on the condition of the country presented 'a gloomy picture of the state of affairs' and, flatly contradicting Reed, he claimed that anti-rent combinations were widespread and that 'in the present temper of the people' this would inevitably lead to violence. Two days later, Hamilton summarized the main dangers posed by the National League and offered suggestions for their legal remedy. ${ }^{222}$

Hamilton also tried to alert Liberal leaders to the imminence of agrarian disorder. On I2 January, he informed Edward Hamilton that Ireland was 'in the throes of a revolution' and argued that the Government faced the 'alternative either of letting Ireland govern herself $[\ldots]$ or of ruling with a rod of iron'. Given that Hamilton's judgment was usually 'singularly sound and calm', this stern warning carried considerable weight. Gladstone was highly impressed and was reported to be 'loud in his praises of that able and excellent Under Secretary. "What a man", he said, "is Sir Robert Hamilton to hold his ground with such boldness, firmness and sagacity [...] and in despite of the ravings, judicial \& other, on this side of the water." "'223

Nevertheless, Hamilton's warnings about the dangerous state of affairs only impelled the Conservatives further towards repression. On I3 December, a Cabinet memorandum claimed that low levels

\footnotetext{
${ }^{221}$ MCR (W) for December i885, Byrne, DM, 4 January i886: CSO, RP I886/5277; 'Progress of the National League: divisional reports for quarter ending 3i December i885', Slacke, DM, ı January I886, Antoine Butler, DM, 4 January I886: CSO RPs I886/647, I886/2 Io in RP I888/26523.

${ }^{222}$ Hamilton to Carnarvon, I2 January I886: CP, Add MS 6o821, fos I6-17; 'Memo. by Mr. Hamilton, dated ${ }^{\text {th }}{ }^{\text {th }}$ January I886 - addressed to Lord Carnarvon' (copy): RCHL I/II. I232.

${ }^{223}$ Hamilton to Edward Hamilton, I2 January I886: EHP, Add MS 48625, fos I-2; Edward Hamilton to Herbert Gladstone, I4 January i886: GP, Add MS 56447, fos 6-7; Edward Hamilton's diary, I3 and I5 January I886: EHP, Add MS 48642, fos 88, 9I-92.
} 
of recorded crime in Ireland concealed 'a baneful system of tyranny, carried out and enforced by local branches of the National League', which might soon have to be met with the most stringent measures. It concluded, 'Whenever it becomes evident that the reign of law and of the National League cannot co-exist, the latter must be made to yield at any cost, and it is impossible to say when this necessity may arise. ${ }^{924}$ With conservative opinion in Ireland calling for a permanent measure 'providing for the final extinction of the outward and visible signs' of illegal or seditious organizations, the hawks within the Cabinet concluded that the most recent reports from Ireland demonstrated that Dublin Castle was irresolute and that the National League had to be confronted. ${ }^{225}$ On 15 January, Churchill suggested that the League's leaders be arrested for high treason, its offices seized, and parliament requested 'to indemnify [the Government] retrospectively for this breach of habeas corpus'. This draconian and unconstitutional plan divided the Cabinet. When it had been suggested to the Irish Attorney-General he had argued that 'the reputation of everyone engaged in carrying it out would be ruined'. Salisbury therefore concluded that the threat of less drastic action against the League might be sufficient to reassure Irish Unionists, ensure a decisive break between his administration and Parnell, and provide him with an opportunity to relinquish an office from which he was 'feverishly eager' to escape. ${ }^{226}$ Contingency planning for a confrontation with the nationalists therefore continued at the War Office, where General Wolseley finalized military plans for the suppression of armed rebellion. ${ }^{227}$

The plan to suppress the National League was met with consternation by those who would have been responsible for its implementation. Hamilton argued that it would prove futile because

\footnotetext{
${ }^{224}$ Irish Office, 'The condition of Ireland', I3 January I886: CP, Add MS 60823, fos IOO-IO4. The probable author of the memorandum was the Irish Attorney-General, Hugh Holmes, who briefed the Cabinet on Ireland on ${ }_{5} 5$ January and redrafted the relevant portion of the Queen's speech in similar vein: see A.B. Cooke and J.R. Vincent, 'Ireland and party politics, I885-7: an unpublished Conservative memoir (I)', IHS, I6, no. 62 (September I968), pp. I68-170.

${ }^{225}$ Fitzgibbon to Churchill, I6 January I886: RCHL I/ I I. I354; Johnson, Diary of Gathorne Hardy, pp. 589-590.

${ }^{226}$ Cooke and Vincent, 'Ireland and party politics', pp. I68-I69; Roberts, Salisbury, pp. 370-37r. Carnarvon was dismayed by Churchill's suggestion to govern Ireland under the Lord Justices and then send Wolseley out as viceroy 'when things grow bad': 'Very remarkable conversation with R. Churchill': CP, Add MS 6o825, fo. I32.

${ }^{227}$ NAI, Crime Special Papers, 236r4/S; Wolseley to Carnarvon, I4 December I885: CP/TNA, PRO 30/6/66, fos I98-I99. W.H. Smith also ascertained from the Prime Minister of Canada that troubles in Ireland were unlikely to increase the threat posed by American Fenians; Smith to Churchill, 3 January I886: RCHL I/II. I242.
} 
the organization's branch structure was 'far more perfect than that of the old Land League'. It would, he advised Carnarvon, be regarded as 'a declaration of war to the death' by the Irish-Americans who largely funded the League, and he predicted that 'many lives would be lost before the country was again subdued into sullen quiet'. He recalled that, upon showing his Cabinet memorandum to W.H. Smith, the Chief Secretary commented 'You may be right; but not one out of 4 or 5 men in Great Britain is prepared to face "Home Rule", to which Hamilton replied that an equal number would oppose the suspension of constitutional government in Ireland, which, he believed, was the only logical and plausible alternative. ${ }^{228}$ The plan was also considered to be impractical and Reed warned Hamilton and Carnarvon that, in the absence of emergency powers, the Constabulary was not equipped to cope with a general outbreak of crime and disorder. His force would, he declared, be as helpless as they had been during the Land War. This view was echoed by Jenkinson, who believed that the intelligence system that he had developed in Ireland had declined during his absence in London. More than a year earlier, he had warned Spencer 'if ever outrages do break out again [...] the present machinery and present system will not be equal to the task. There will be as certainly a break down again as there was a break down in i88ı.' He now argued that the RIC required substantial reinforcement before it could cope with the consequences of the League's 'overthrow'. 'It could be like poking the fire', he warned Carnarvon; 'a blaze would follow which could not be extinguished without very exceptional powers and by vigorous action [...] The safety valve would be shut down, and instead of one open society, we should have several secret societies in their worst form to deal with. ${ }^{229}$ Such advice was unlikely to have been welcome in Westminster, but Carnarvon had done his best to convince his colleagues to take Jenkinson's advice seriously, telling Sir Michael Hicks Beach that it was 'simple madness' to disregard the danger that Irish republicans would engage 'in outrage of all kinds on the failure of the Irish Parliamentary Party to come to terms with the Government'. ${ }^{230}$

The Cabinet was under pressure from parliament to state its intentions towards Ireland, and it was agreed on 23 January to

\footnotetext{
${ }^{228}$ Document 44; Edward Hamilton's diary, I3 February I886: EHP, Add MS 48643, fo. I3. Hamilton simultaneously briefed Spencer on the situation: see Document 43.

${ }^{229}$ Jenkinson to Spencer, 7 November I884: AP, Add MS 77035; Documents 42 and 45.

${ }^{230}$ Carnarvon to Salisbury, 3 and 7 January I886; Salisbury to Carnarvon, 6 January I886: CP/TNA, PRO 30/6/62 (48), (53), (52). Carnarvon to Hicks Beach, 3 January ı886: SAP, D2455, PCC/46; Carnarvon to Churchill, 3January i886: RCHL i/II. I240. Cross to Carnarvon, 4January i886; Ashbourne to Cross, 4 and 6 January i886: BL, Cross Papers, Add MS 51276 , fos $2-5$.
} 
accommodate Smith, who was alarmed by the sudden growth of an urban 'House League', by announcing firm action against the National League. ${ }^{23}$ After signalling an intention to tackle 'concerted resistance to the enforcement of legal obligations' in the Queen's speech, the Government announced the introduction of a bill for the suppression of the League on 26 January. ${ }^{232}$ This had the effect, so the Irish Attorney-General later recalled, 'of putting the government out of pain'. Gladstone, however, astutely refrained from challenging the ministry on the issue of Ireland and thus avoided committing himself to home rule at this stage. ${ }^{233}$

\section{The Home Rule Bill and its Consequences}

After the Liberals assumed office on I February i886, Hamilton did all he could to persuade the Irish law officers, including the highly sceptical Lord Chancellor, to serve a home rule administration. He anticipated events by advising Spencer to remain in London to assist in the development of legislation, and to leave Irish administration to John Morley, who enjoyed the trust of the Irish Parliamentary Party. Above all, he wanted to assure the new ministry that Ireland was in a fit state to accommodate constitutional reform. Gladstone and Spencer were aware that the social and political circumstances that had made home rule necessary might also obstruct its implementation. ${ }^{234}$ Gladstone had warned Granville that further unrest in Ireland might 'effectually thrust aside' any declaration on home rule and, shortly afterwards, Spencer admitted to Lansdowne that, even if Parnell were to accept the government's proposals, 'the social state of Ireland may be found to be too bad to allow us to proceed'. ${ }^{235}$

Hamilton was eager to assure Spencer that the National League was now doing all it could to curb the excesses of some of its branches, but advised that Ireland remained in a volatile condition. With home

\footnotetext{
${ }^{231}$ Holmes to Kaye, 27 January I886: CSO RP 1886/1748; and see B.J. Graham and Susan Hood, 'Town tenant protest in late nineteenth- and early twentieth-century Ireland', Irish Economic and Social History, 2 I (1994), pp. 39-57.

${ }^{232}$ Her Majesty's Most Gracious Speech to Both Houses of Parliament, 2I January I886. A bill was drafted on 27 January: W.F. Cullinan to Ashbourne, 3 February 1886, repr. Cooke and Malcolmson, Ashbourne Papers, p. Io6.

${ }^{233}$ Cooke and Vincent, 'Ireland and party politics', p. I72. Instead, the Liberals carried an amendment to the address in favour of agricultural labourers against the Government.

${ }^{234}$ Document 4o; Hamilton to Spencer, 7 February, 28 March 1886; Gladstone to Spencer, 28 December i 885: AP, Add MSS 7706I, 76863; Gladstone, 'Secret memorandum', 3I December I885: GP, Add MS 56446, fos 223-225.

${ }^{235}$ Gladstone to Granville, I8 January I886: GP, Add MS 56447 , fos Io-II; Spencer to Lansdowne, 2 February I886, repr. RE, II, pp. Io7-Io9.
} 
rule close at hand, Hamilton was prepared to accept Reed's opinion that the League's leaders currently thought that it served their cause 'better to preserve peace and order in the country'. Privately, however, he admitted to Edward Hamilton 'that at present Ireland is not governed. We are at the mercy of the National League, who think it good policy to do what they can to keep down actual outrages. ${ }^{{ }_{2} 36}$ This sense of foreboding was reflected in the reports of some of Reed's senior officers, who painted an even bleaker picture of the country. Reports from the south-west told of strained landlord-tenant relations, impending evictions, widespread boycotting, and whole districts falling into 'a most lawless state'.${ }^{237}$ The prevailing view from the Constabulary was that home rule meant separation, an opinion most fully articulated by the County Inspector of Limerick at the end of February 1886, when he informed Dublin Castle that

All the elements of Fenianism, and the Irish Republican Brotherhood are at present awaiting an opportunity to strike: And keeping quiet merely so long as the milder form of Nationalism acting under Constitutional guise continues to gain ground towards the common good. The National aspiration is independence - pure and simple - and nothing short of actual separation from England will satisfy the people of the Irish race. The more I study their character the more I am convinced of this; and any decided check to the National Movement would, in my opinion, be the signal for an outburst of those elements of Fenianism \& Republicanism, which, under different names and guises, lie dormant watching the progress of events. ${ }^{238}$

Setting these warnings aside, Hamilton concentrated on preparing the way for home rule and advised Spencer to put the Lord Lieutenancy into commission, on the ground that 'unless a dummy came here I should dread embarrassment \& all our hands at a time like this should be as free as possible'. The appointment of Morley as Chief Secretary and Lord Aberdeen as a subordinate Lord Lieutenant met with the Under-Secretary's approval. Hamilton found that Morley was 'very clear and decided and works without any fuss', and in turn Morley recalled that Hamilton was 'a man of experience and ability, and in firm sympathy with the new policy'. ${ }^{239}$ The new arrangement antagonized some Irish Conservatives, who drew attention to the prominent part being taken by Hamilton and Fottrell in policy making.

\footnotetext{
${ }^{236}$ Hamilton to Spencer, I February I886: AP, Add MS 7706I; MCR (IG) for January I886, Reed, 6 February i886: CSO RP ı886/6691; Edward Hamilton's diary, 23 March I886: EHP, Add MS 48643, fo. 52.

${ }^{237}$ CI Q. J. Brownrigg to Plunkett, DM, 3 February I886: CSO RP I886/2259.

${ }^{238}$ CI Xaverius Butler to Plunkett, DM, 28 February I886: CSO RP I886/487o.

${ }^{239}$ Hamilton to Spencer, 3 and 4 February I886: AP, Add MS 7706r; Morley, Recollections, I, p. 22I.
} 
On I4 February, Gerald FitzGibbon furnished Churchill with the latest 'local gossip' from Dublin:

At the Castle, as soon as the swearing was over there was a Cabinet Council of four - i. Aberdeen L.L. ii. John Morley C.S. iii. Sir Robert Hamilton, late of the Orkneys, Privy Council Office, Board of Trade, Navy, and other foreign parts, and iv. George Fottrell, ex solicitor (dismissed) of the Land Commission!!! The Lord Chancellor, Attorney General, and Solicitor General, were in attendance, outside, for three hours, and were never called in at all! So runs the story, and in the evening the Viceroy \& Chief Sec. returned to the places whence they camewiser and more cheerful men - prepared to pacify the Country on Fottrell's lines - which are as follows: A compulsory Land Purchase Bill to be brought in at once, to do whatever is the opposite of 'making the running' for Home Rule - which is to be thought over in the meantime. ${ }^{240}$

The idea that Hamilton drafted Gladstone's first home rule bill persisted for many years. While this is incorrect, it is true that he played an important part in its development. ${ }^{241}$ Before Gladstone withdrew to Mentmore to formulate the legislation, Hamilton provided both him and Spencer with copies of his Cabinet memorandum. This evidently made an impression in Whitehall, and Edward Hamilton recorded that the paper practically advocated 'an extensive Home Rule scheme' that exhibited 'full consciousness of the dangers \& difficulties surrounding it' ${ }^{2{ }^{2}}$ The Irish Under-Secretary subsequently travelled to London to discuss the matter with members of the Cabinet and suggested a number of amendments to Gladstone's proposals on Irish government and finance. Hamilton's views were regarded at Westminster as those 'of a high-minded man who has more knowledge of Irish Executive matters than any one else, who went to Ireland unprejudiced, \& whose mind has been bent in this direction solely by conviction'. As such, Edward Hamilton recorded, 'They cannot help weighing with one. ${ }^{243}$

Three key issues required careful consideration before a home rule bill could be framed - the land question, policing, and the response to home rule in Protestant-dominated areas of Ulster. Within

\footnotetext{
${ }^{240}$ FitzGibbon to Churchill, I4 February I886: RCHL I/I2. I380. For Fottrell's account, see Journal (16 February I886).

${ }^{241}$ Dictionary of National Biography: second supplement, p. 382.

${ }^{242}$ Document 2o; Hamilton to Spencer, I and 2 February I886: AP, Add MS 7706r;
} Edward Hamilton's diary, i February i886: EHP, Add MS 48643, fo. 9; and see John Kendle, Ireland and the Federal Solution: the debate over the United Kingdom constitution, I870-I920 (Buffalo, I989), pp. 42-43.

${ }^{243}$ Journal (I6 February 1886); Hamilton to Spencer, 7 February, 24 March I886: AP, Add MS 7706r; 'Sir R. Hamilton's notes. Irish Govt.', 29 March r886: AP, Add MS 77328; Edward Hamilton's diary, II and i3 February, 23 March I886: EHP, Add MS 48643, fos Io, I2, 52 . 
each of these policy areas, Jenkinson and Hamilton made significant contributions to the debate. The viability of home rule depended to a large extent upon the future constitutional position of Ulster, yet this question received scant attention from Gladstone because the fate of Ireland's landlords dominated his thinking. ${ }^{24}$ The Liberal leader's complacency over this vexed question may have derived, at least in part, from advice he received from Jenkinson, whose views on the probable reaction of Ulster's Protestants to home rule were highly optimistic. Having dismissed the possibilities that Irish Protestants would be persecuted by the Catholic majority or that civil war might ensue, he cited the 'many Protestants in the National Ranks' as evidence of Ulster's acquiescence to home rule. ${ }^{245}$

In fact, Jenkinson's views on Ulster had changed significantly since October I883. At the height of the National League's 'invasion' of the province, Jenkinson had disobeyed an order from the Chief Secretary to have placards calling for counter-demonstrations removed. Jenkinson had then argued that the Orange Order had a legitimate right to organize in self-defence, which led Trevelyan to charge him with holding 'unstatesmanlike Orange opinions' and being 'absolutely ignorant of the very elements of constitutional government'. ${ }^{246}$ The much more sanguine view of Ulster that Jenkinson presented at the end of 1885 was likely to have been music to the ears of Gladstone, who viewed the annihilation of the Liberal Party in Ireland as a political opportunity. He regarded Ulster as a 'fraction of a nation', which was now solely represented 'by Tories or by Parnellites'. 'Perhaps had we large and cordial Ulster support', he admitted to James Bryce, 'it might have abridged our freedom more than it would have enlarged our votes. ${ }^{{ }^{247}}$ Nevertheless, soon after the general election Gladstone's supporters received warnings that the province was far from quiet. In mid-December, Edward Hamilton recorded the views of the Liberal peer Lord Waveney, who reported that 'the Ulstermen are ready to rise to a man if there is any paltering with Parnell'. Bryce also reported that widespread fear that Protestant interests were in jeopardy had provoked fiery language from the Orange lodges. ${ }^{24^{8}} \mathrm{~A}$ second report from Bryce in March 1886 challenged Jenkinson's optimistic predictions: he

\footnotetext{
${ }^{244}$ Matthew, Gladstone, p. 487. This matter is most fully considered in Loughlin, Gladstone, Home Rule and the Ulster Question.

${ }^{245}$ Documents 15 and 27.

${ }^{246}$ Trevelyan to Spencer, 29 October I883: AP, Add MS 76959.

${ }^{247}$ Gladstone to James Bryce, 2 December 1885 , repr. GD, XI, p. 439.

${ }^{248}$ It was said that Waveney had returned from Ulster 'an altered man': Edward Hamilton's diary, I7 December 1885: EHP, Add MS 48642, fo. 54; Bryce, 'Irish opinion on the Irish problem', I I December 1885: GP, Add MS 44770, fos 5-I4.
} 
considered that Ulster Liberals were 'practically unanimous in their hostility' to measures that might leave them subject to a nationalistdominated assembly, and predicted that moderates would join with Tories and Orangemen to oppose home rule. He recommended that the forthcoming bill should restrict the power exercised by a Dublin parliament over Protestant-dominated regions of Ulster, which should in turn be provided with local self-government. Charles Russell tried to assure Gladstone that the violent opinions recorded by Bryce were largely the product of anti-Catholic prejudice, but even he conceded that Liberal opinion in Ulster was largely against home rule. ${ }^{249}$

Jenkinson's optimism about Ulster was not widely shared by those whom he had once served in Dublin. Spencer abhorred sectarianism but accepted that conflict was an inescapable feature of political life in Ulster. The rough treatment that he had received from loyalists during a visit to Belfast in June $188_{4}$ hardened his resistance to home rule. 'The North would never agree to it', he had then warned Jenkinson, 'we should at once have civil war between Ulster and the South and West.' This view had been shared by Trevelyan who, in December I883, had confided to his sister, 'If these people were left to themselves, we should have a mutual massacre; unless they are not quite as brave as they pretend.' While neither man believed that Irish Protestants would suffer persecution under home rule, both understood the alarm felt by Ulster Liberals about the establishment of an Irish parliament. Nevertheless, the true extent of popular loyalist opposition to home rule was not clearly understood by many English Liberals until serious sectarian riots broke out in Belfast in June I 886. ${ }^{25^{\circ}}$

The most pressing administrative issue, one thought by some to be 'the real crux' of the home rule question, concerned the future of the Irish police. ${ }^{251}$ Given that the RIC was an imperial armed force that had recently been in conflict with the nationalists, its status under home rule was bound to cause controversy. It was a question that revealed the limit to which British officials were prepared to trust a nationalist government of Ireland as they considered the danger that an independent Irish parliament might use the Constabulary as

\footnotetext{
${ }^{249}$ Bryce to Gladstone, I2 March I886: GP, Add MS 56447 , fos 64-75; Russell to Gladstone, I7 March 1886: GP, Add MS 56447, fos 76-90.

${ }^{250}$ Document 3; G.M. Trevelyan, George Otto Trevelyan: a memoir (London, I932), p. II5; Spencer to Gladstone, 3г December i885: GP, Add MS 443², fos 245-246. Jenkinson, however, continued to believe that it was 'absurd to believe that Ulster would fight' in the event of home rule: Liverpool Mercury, I I March I893, p. 5.

${ }^{251}$ The view of Sir Henry Thring: Edward Hamilton's diary, 9 November 1885 : EHP Add MS 48642 , fo. 5 .
} 
an instrument of warfare. ${ }^{25^{2}}$ It is telling that even Hamilton thought that it might still be necessary to use the Constabulary to protect the Protestant and landed minorities after home rule was granted. In October 1885, he had recommended that the British Government should retain control of the RIC, arguing that the capacity to concentrate this semi-military force at any given point would deter a future Irish government from behaving unconstitutionally. As home rule became more likely in December i885, concern grew over police morale. Hamilton was aware that the RIC had become demoralized by ad hoc reforms to its administration over previous years, and that the prospect of home rule had caused 'great consternation' among its members. ${ }^{253}$ On io December, Reed warned the Castle that, if his men came to believe that they were to be 'handed over to their enemies the Nationalists and Fenians [...] to do with the Constabulary as they think fit', it was not unreasonable to expect that their loyalty would be shaken, 'their interest in the British Government diminish, and their efficiency become seriously impaired (if worse consequences do not follow) ${ }^{254}$

Faced by the prospect of mutiny, the Inspector-General sought assurances that the interests of his men would be protected under any new constitutional arrangement. Carnarvon gave Reed his personal assurance that this would be done and, in the light of 'a seditious and very dangerous paper' then being circulated amongst the Constabulary, recommended that the Prime Minister promise to Parliament that the RIC would always remain an imperial force. ${ }^{255}$ Spencer, however, doubted whether the imperial parliament would be able to retain control of the RIC after home rule was granted and predicted that local authorities would insist on establishing their own police forces. Consequently, he advised Gladstone that 'this Irish Army' should be disbanded to prevent it being turned against British authority. Gladstone, on the other hand, held 'not the smallest fear' that this would happen. He had always viewed the RIC as an expensive drain upon the Exchequer and believed that it could be harmlessly broken up into about forty county and municipal forces. ${ }^{25^{6}}$ Nevertheless, threats from leading nationalists to exact 'revenge' upon the police after home rule was secured did little to calm the

${ }^{252}$ T. Cooke Trench, 'Seeking for an Irish policy', I2 November 1885; Carnarvon to Trench, 25 December 1885: CP, Add MS 60820, fo. 45.

${ }^{253}$ Documents 2o, 32, 33, 36, and 37 .

${ }^{254} \mathrm{MCR}$ (IG) for November I885, Reed, io December I885: CP/TNA, PRO 30/6/64 (38).

${ }^{255}$ Carnarvon, 'Mr Reed', 3I December i885; Carnarvon to Salisbury, 22 January i886: CP, Add MSS 6o823, fo. 97, 60825, fo. 92.

${ }^{256}$ Documents 36 and 39; Gladstone to Spencer, 8 September I882: AP, Add MS 76856. 
Constabulary's nerves. Subsequent reports from senior officers, one of whom claimed 'that two thirds of the men would rather resign than serve under a Home Rule Government', forced the new Liberal administration to address the question. ${ }^{257}$ Gladstone still refused to accept that policing would present 'an insurmountable difficulty', but others, such as George Trevelyan, were more concerned about the need to curb nationalist ambitions. As Chief Secretary in I882, he had faced strikes by sections of the Constabulary and Dublin Metropolitian Police and he predicted that the British Government would continue to rely upon the RIC to maintain order in Ireland. ${ }^{25^{8}}$ His fears were widely shared in Dublin. Hamilton was eager that the force would 'in no circumstances be handed over with their present organization to an Irish Parliament' and, largely due to pressure from the English Lord Chancellor, the Home Rule Bill stipulated that the Constabulary would remain under imperial control. ${ }^{259}$

Some of Gladstone's advisers believed that the safest way to bring the police under Irish control would be to first settle the land question, so that the legal enforcement of contracts would be seen to serve the general public interest. The land question was widely regarded as the biggest obstacle to home rule, largely because its solution threatened the interests of British taxpayers, and it has been cited as the most important reason for the failure of Gladstone's policy. Uncertainty over home rule threatened to destabilize the Irish economy: in December 1885, Carnarvon drew the attention of the Cabinet to 'a sort of panic in certain classes, \& a fall of securities' caused by the Hawarden Kite. A month later, Hamilton alerted Spencer to fears that English opinion might turn against home rule because of the alarm caused to British financiers over the security of funds advanced on Irish land. ${ }^{260}$ Some proponents of home rule therefore insisted that a prior and definitive settlement of the land question was integral to its success, and it was on this question that Irish officials most actively counselled the politicians.

The success of a land purchase scheme depended upon its capacity to satisfy both Irish landlords and tenants without casting an undue burden on British taxpayers. It was therefore important to persuade rank and file Liberals that a 'scheme of outdoor relief

${ }^{257}$ F.S.L. Lyons, fohn Dillon (London, I968), pp. 86-87; Brownrigg to Plunkett, DM, 28 February i886: CSO RP I886/4870.

${ }^{25^{8}}$ Gladstone to Granville, I 8 December I885: GP, Add MS 56466 , fos I93-I95; CampbellBannerman to Spencer, 8 January i886, repr. J.A. Spender, The Life of the Rt. Hon. Sir Henry Campbell-Bannerman, GCB, 2 vols (London, I923), I, pp. 95-97.

${ }^{259}$ Hamilton to Spencer, 2 February 1886; Lord Herschell to Spencer, in April I886: AP, Add MSS 7706r, 77324 .

${ }^{260}$ Carnarvon to Cranbrook, I9 December i885: CP, Add MS 60825, fo. I59; Document 37; and see Peter Cain and Tony Hopkins, British Imperialism, I688-2000 (London, 2001), p. I30. 
for the Irish landlords' was not being contemplated. The scale of the proposed government loan to finance the scheme (Gladstone originally suggested a figure of $\mathcal{E}_{\mathrm{II}} 3$ million) was hotly debated in English constituencies. Progressive Liberals exhibited a strong aversion to the measure, which they regarded as a 'costly attempt to buy the acquiescence of the landlords in a policy of separation', and its adoption precipitated the resignations of Chamberlain and Trevelyan from the Cabinet. The Land Purchase Bill was abandoned soon after its first reading in April I886 when it was recognized as a political liability, and its close association with the Home Rule Bill was something that Gladstone came to regret. Nevertheless, it has been convincingly argued that the land purchase scheme was far from being a 'dummy' bill and actually formed part of a coherent effort to tackle agrarian unrest and 'lay the foundations of a more secure social order in Ireland'. Fottrell's journal demonstrates that Liberal thinking on the land question was much influenced by the ideas of Sir Robert Giffen, a former Board of Trade economist with whom he held several meetings. Yet Gladstone's decision to adopt land purchase was, at least in part, influenced by views that he received from Ireland. ${ }^{261}$

Land purchase was supported by many Catholic bishops, on the ground that an equitable solution to the land question was necessary if the rural population was to thrive in its native land. Fottrell regarded land purchase as 'a necessary complement to self-government' and Morley relied heavily upon his advice concerning the order in which the land and home rule questions should be tackled. ${ }^{262}$ Fottrell recognized that home rule would have a tremendous impact upon the status quo in Ireland. He hoped that an equitable land purchase scheme would disarm landowners' opposition to the policy by providing them with the opportunity to dispose of their land at a reasonable price and thus reach an accommodation with Irish nationalism, as had been urged by Isaac Butt in the I87os. Fottrell's scheme made the Irish state an intermediary between landlord and tenant, providing state aid to landlords who were willing to sell without imposing compulsory purchase on those who were not, and a summary of his paper was circulated to the Cabinet. ${ }^{263}$

As with home rule, Spencer had to be persuaded of the virtues of land purchase. Since I884, he had been eager to ease stagnation in the Irish land market, which, he believed, had resulted from the

\footnotetext{
${ }^{261}$ Graham D. Goodlad, 'The Liberal Party and Gladstone's Land Purchase Bill of I886', Historical Fournal 32 (1989), pp. 627-64I; Journal (I7 January, I6 February, 2 March 1886).

${ }^{262}$ Archbishop Walsh to Gladstone, I7 February I886: GP, Add MS 56447 ; Journal (i6 February 1886).

${ }^{263}$ Journal (I, 21 March 1886).
} 
nationalists raising unrealistic expectations of the Land Act, and he had briefly considered establishing an Irish land bank. He was convinced, however, that the principle of dual ownership established by the Land Act was correct and remained optimistic that the Land Commission would improve landlord-tenant relations. He wanted it to be universally understood that the Act represented a final and definitive settlement of the land question and that there was no profit to be gained from further agitation. Spencer's thoughts on land purchase subsequently changed and, in spite of criticizing aspects of the Ashbourne Act of August I885, he privately welcomed the measure as a stimulant for the stagnant land market. ${ }^{264}$ Jenkinson, however, was not convinced that a workable settlement had yet been achieved and tried to persuade Spencer that comprehensive land purchase was necessary. His administrative experience of India convinced him that problems that had not proved insurmountable in a far larger country than Ireland might also be solved there. Jenkinson's arguments carried weight with Spencer who, in I882, had considered him for a place on the Land Commission. ${ }^{26}$ Having little sympathy for Irish landlords, most of whom he regarded as short-sighted, selfish, and cowardly, Jenkinson had once advised Carnarvon to check 'the excessive zeal' shown towards insolvent tenants by withholding police protection from unreasonable land agents. 'In England', he protested, 'we do not see the military and the Police assisting agents in summarily evicting tenants'. If assistance was to be given, he argued, the Government ought to ensure that it was not being asked to act with undue harshness against tenants. 'Why', he asked, 'in order to put money in the pocket of a landlord should the Government turn a tenant and his family out of his house and ruin him?' At the same time, he did believe that, in spite of their political extinction as a class, Irish landlords ought to have their legitimate interests protected. Like Gladstone, he recognized that, having shaped the country's land code, the imperial parliament was obliged to ensure that the transfer of land to its occupiers was made on terms acceptable to its owners. ${ }^{26}$

Hamilton also believed that a comprehensive land settlement was essential. He, too, had little time for Irish landlords, whom,

\footnotetext{
${ }^{264}$ Spencer to Gladstone, 28 February I884, repr. RE, I, pp. 263-265; Spencer to Granville, 22 October 1884: AP, Add MS 76884; Spencer to Lansdowne, I6 August i885, repr. RE, II, pp. $70-74$.

${ }^{265}$ Spencer to Trevelyan, 20 July 1882; Trevelyan to Spencer, 22 July I882: AP, Add MS 76947. Jenkinson, 'Memorandum on the operation of the Irish Land Commission', I5 July I882: $\mathrm{CAB} 37 / 8 / 42$.

${ }^{266}$ B. Mallet, Thomas George, Earl of Northbrook (London, I908), p. I64; Jenkinson to Carnarvon, I2 September 1885: CP/TNA, PRO 30/6/62 (27); Document 3i; Goodlad, 'Liberal Party', p. 628.
} 
he considered, had 'too long relied upon English bayonets to protect their rights'. He was, however, alert to the danger that the destruction of Irish landlords as a class would remove an important obstacle to separation, and accepted that the British Government was duty-bound to protect them. On 27 December, Hamilton set out a detailed scheme for facilitating land purchase within a falling market, under which the new Irish state would become the country's largest landowner. He was particularly concerned about the plight of insolvent tenants on large unprofitable landholdings in the west of Ireland and offered advice on rents, land valuation, and the development of safeguards for smallholders. ${ }^{267}$ Gladstone resisted Parnell's suggestion that the compulsory purchase of such landholdings would greatly reduce opposition to home rule from landowners. He disliked the idea of state intervention in the land market and was concerned that the Irish tenant's 'long standing antipathy towards the institution of landlordism' would merely be redirected against the Government. ${ }^{268}$ But while he saw no virtue in making the state a principal landowner, Gladstone did admit that Hamilton's suggestion for making the Irish parliament responsible for land purchase arrangements was of 'great value' and worthy of further investigation. ${ }^{269}$

As with policing, however, some pro-home-rule Liberals doubted the capacity of an Irish parliament to treat the land question judiciously. The idea that land purchase should precede home rule was partly founded upon doubts about the safety of leaving the matter at the discretion of men whose anti-landlord bias might be the ruin of Irish agriculture. By the end of 1885 , Spencer accepted that a comprehensive land purchase scheme was the only means of avoiding a wholesale exodus of the landed interest from Ireland. For him, it also had the advantage of allowing the Land Commission to be dissolved and thus saved from the 'partiality \& violence' of the Parnellites. ${ }^{270}$ As an Ulsterman, the Irish Attorney-General, Samuel Walker, was also firmly opposed to the Irish state assuming responsibility for the land question on the ground that 'Ulster tenants would not trust an Irish administration to treat them fairly'. He wanted merely to expand the

\footnotetext{
${ }^{267}$ Hamilton to Spencer, I7 January, 3 and 27 February, 2 March I886; Spencer to Hamilton, 23 February, I March I886: AP, Add MS 7706r. Edward Hamilton's diary, I3 February I886: EHP, Add MS 48643, fo. I3; Hamilton, 'Smallholdings in Ireland', I8 February I886: GP, Add MS 44632, fos 56-6r; and see Documents 32, 37, and 43.

${ }^{268}$ Gladstone to O'Shea, 9 January I886, repr. GD, XI, p. 477; Walsh to Gladstone, I7 February I886: GP, Add MS 56447, fos 35-40.

${ }^{269}$ Gladstone to Spencer, I4 January I886, repr. GD, XI, p. 479.

${ }^{270}$ Document 36 ; and see 'Confidential. Land purchase. Memorandum of G[eorge] F[ottrell]', i March i886: GP, Add MS 44632, fos I77-184.
} 
Ashbourne Act in order to create a larger land purchase fund. Like Jenkinson, he did not believe that a nationalist-dominated authority would be resilient enough to withstand the demands of Catholic tenant farmers, and recommended that control of land purchase should remain with the imperial parliament. ${ }^{27}$ This view was supported by police reports from the south-west that claimed that younger men in disaffected districts were beyond the control of the National League. If nationalist aspirations were checked, it was warned, 'Fenianism would again become rampant' and result in 'the confiscation to their own use of the land and property of the Country'. A consensus therefore developed at Dublin Castle that it would be unwise to trust a settlement of the land question to an Irish legislature. It was an aspect of the Irish question that was to be effectively exploited by Liberal opponents of home rule. ${ }^{272}$

Once the home rule bill had been drafted, Hamilton was opposed to making any amendments that might alienate the Irish Parliamentary Party and so render the legislation unworkable. ${ }^{273}$ The progress of the Home Rule and Land Purchase Bills as viewed from the perspective of Dublin political society is vividly recounted by George Fottrell, who, at Morley's request, tried to persuade Chamberlain not to break ranks over Ireland. ${ }^{274}$ That Chamberlain was not open to persuasion was regarded as a severe blow. As Balfour intimated to Salisbury, it was Chamberlain and not Hartington who could do most to destroy Gladstone's scheme, and he predicted that they would 'find in him so long as he agrees with us a very different kind of ally from those lukewarm and slippery Whigs whom it is difficult to differ from and impossible to act with'. It was therefore clear that divisions within the Liberal Party would doom the Home Rule Bill and, by early summer, hopes for its success had begun to fade in Dublin. ${ }^{275}$

The manner in which Hamilton and Jenkinson became embroiled in the home rule controversy brought into question their status as permanent civil servants, and had serious consequences for their subsequent careers. After 1854, when the position of Irish undersecretary was made a permanent one, incumbents were expected to abjure involvement in party politics. That the home rule question had

\footnotetext{
${ }^{271}$ Samuel Walker to Spencer, Io March I886: GP, Add MS 56447, fos 56-62.

${ }^{272}$ CI Charles Cameron to Plunkett, I April 1886; Plunkett to Hamilton, 2 April I886: CSO RP ı886/6976; Goodlad, 'Liberal Party', pp. 632, 635.

${ }^{273}$ Edward Hamilton's diary, 23 March I886: EHP, Add MS 48643, fo. 52; Document $4^{6}$.

${ }^{274}$ See Journal (12 March 1886$)$.

${ }^{275}$ Balfour to Salisbury, 22 March I886: JCP, JCi/4/4/6; Hamilton to Spencer, 3 June I886: AP, Add MS 7706r; and see W.C. Lubenow, Parliamentary Politics and the Home Rule Crisis: the British House of Commons in I886 (Oxford, 1988).
} 
rendered this impossible was attested to when, in 1889 , Randolph Churchill advised Arthur Balfour that 'Hamilton \& Jenkinson are splendid examples of the danger of not being certain that in yr. permanent officials you have not emissaries from the camp of the enemy. ${ }^{{ }_{227} 6}$ While both men retained their posts after the Conservatives returned to power in July i886, it soon became clear that their days in office were numbered. Close study of the Chief Secretary's Office papers of the period indicates that the Chief Secretary, Sir Michael Hicks Beach, and his Attorney-General conducted most of their business through the Assistant Under-Secretary, Sir William Kaye, one of a number of Conservatives within the Irish administration. ${ }^{277}$ Hicks Beach had never really trusted Hamilton. In July i 885 , he had advised Carnarvon to 'please remember that Sir R. Hamilton is a Whig: and, like a Whig could wish nothing better than that we should follow in the footsteps of the late Govt., with similar failure ${ }^{9}{ }^{27^{8}}$ When, in August I886, Morley assured him that Hamilton was 'in no sense the fountain of the evil' of home rule, Hicks Beach replied that 'he did not see how you could have a vigorous executive when the head of it was a man notoriously hostile to the whole system', and then criticized Carnarvon for 'inviting Hamilton to talk politics'. ${ }^{279}$ The UnderSecretary incurred further disfavour for his unenthusiastic response to the appointment of Sir Redvers Buller as Special Commissioner for Cork and Kerry. Buller claimed that the Home Rule Bill had demoralized the entire administrative class and that Irish officials were 'shockingly weak kneed'. He advised Hicks Beach that any attempt to stiffen their resolve would be undermined by the continued presence of Hamilton, whom Buller described as 'a clerk of clerks, whose soul is red tape, and whose idea of initiative is the avoidance of responsibility'. Fottrell documents the subsequent press campaign against the UnderSecretary mounted by The Times and St Fames Gazette in the second half of $1886 .{ }^{280}$

Although Hamilton was perturbed by these attacks, he saw 'no immediate prospect of the fulfilment of the kind wishes of the London press' that he should be 'promoted', and was persuaded to avoid becoming embroiled in the controversy. Instead, Spencer publicly

\footnotetext{
${ }^{276}$ Churchill to Balfour, 9 July I889: BL, Balfour Papers, Add MS 49695, fo. I79.

${ }^{277}$ From I853, Kaye had registered voters on behalf of the Conservatives and, in I859, was secretary of the Central Conservative Society of Ireland: Andrew Shields, 'The Conservative Party in Ireland, I832-67', unpublished $\mathrm{PhD}$ thesis (University of Toronto); James Stronge MP to Earl of Mayo, I9 December I867: NLI, Mayo Papers, MS 43852/7.

${ }^{278}$ Hicks Beach to Carnarvon, I7 July I885: CP/TNA, PRO 30/6/ 57 , fos I9I-I93.

${ }^{279}$ Morley to Spencer, ro August i886: AP, Add MS 76938.

${ }^{280}$ Buller to Hicks Beach, I6 and 26 October i886: SAP, D2455, PCC/45; Journal (5 December 1886).
} 
defended Hamilton from accusations of impropriety and privately assured Carnarvon that he had, by and large, arrived at his position on home rule independently of Hamilton's influence. ${ }^{281}$ He stated 'with perfect certainty that Mr. Gladstone never saw any paper of Sir R. Hamilton's before he had drawn up the first heads of his policy'. Subsequently, he admitted that he and Hamilton had corresponded in 'general terms' on the question of home rule in mid-December I885 but Carnarvon, in his concern for Hamilton's reputation, advised Spencer against disclosing this information. ${ }^{282}$ In November i886, Hamilton was persuaded to accept the post of Governor of Tasmania - his removal from Ireland being, he declared, 'entirely the act of the Government' - and he was replaced by Buller. ${ }^{283}$ The Liberals' suspicion that the Government had 'really shoved [Hamilton] out of office' meant that the position of Irish undersecretary was subsequently politicized as successive administrations appointed men who were in sympathy with their policies. ${ }^{284}$ Sir Joseph West Ridgeway, who succeeded Buller in I887, did not survive the fall of the Unionist ministry in April I892, when Morley informed Spencer, 'he will have to go [...] He is, I hear in the Castle itself, pure Balfourian and soldier. ${ }^{2{ }_{20}{ }_{5}} \mathrm{~A}$ valuable continuity in the exercise of executive authority was therefore sacrificed as the post was successively filled by appointees who, one incumbent commented, 'could not avoid importing the political views of their party in such a way as to influence the whole administration of the executive' ${ }^{286}$

Edward Jenkinson's position had always been more precarious than that of Hamilton and his support for home rule was to prove even more costly to him. It was some years before Unionists came to suspect that

\footnotetext{
${ }^{281}$ See his address to National Liberal Federation delegates at Leicester: The Times, 26 November I886, p. 6.

${ }^{282}$ Spencer to Carnarvon, 4 and 5 August I886; Carnarvon to Spencer, 6 August I886: CP, Add MS 6o83o, fos 56-62.

${ }^{283}$ Hamilton to Campbell-Bannerman, 24 November 1886: BL, Campbell-Bannerman Papers, Add MS 4I232, fos 313-314; Hamilton to Spencer, 7 and 28 October I886: AP, Add MS 7706r.

${ }^{284}$ Cooke and Vincent, 'Ireland and party politics', p. 333. For a justification of the decision, see The Times, 23 April ı895, p. I3; and for Hamilton's defence of his own actions, see Document 47.

${ }^{285}$ Morley to Spencer, I2 April I892: AP, Add MS 76940; MacBride, Greening of Dublin Castle, pp. 49-51.

${ }^{286}$ David Harrel, Recollections and Reflections (unpublished, I926), p. 91: TCD, MS 3918a. The notion that Harrel was himself above politics is belied by his remark to Carnarvon in I885 that he 'dreaded for Ireland the return of a Liberal Govt.', and his later tribute to Arthur Balfour as 'a real benefactor to Ireland': Flanagan, 'Chief Secretary's Office', p. 209; Carnarvon, 'Conversation with Harrel', 28 November I885: CP/TNA, PRO 30/6/67, fo. 29; Harrel, Recollections, p. I02.
} 
he had warned Gladstone of the imminent dangers of withholding home rule. And yet, while the reasons for his removal from office were chiefly administrative, his position was also undermined by more immediate political contingencies. As Chief Secretary, John Morley wished to placate Parnellite demands for the retrenchment of Irish expenditure and therefore abolished the post of Assistant UnderSecretary for Police and Crime. ${ }^{287}$ Jenkinson's Indian background had always made him an object of intense suspicion to Irish Nationalists and, with his home rule sympathies apparently unknown to them, they associated him with acts that, as Morley explained, 'the most active members of Mr. Parnell's party have always felt themselves bound publicly to denounce, and about which they still profess to feel bitterly'. ${ }^{288}$

Jenkinson continued his secret service work in London during I886, but the Liberal Home Secretary, Hugh Childers, was no more willing to provide him with a permanent position than his predecessor had been. Although Jenkinson's freedom of action was increasingly circumscribed, he persevered in trying to persuade the subsequent Conservative ministry that a definitive settlement of the Irish question was still within reach. ${ }^{289}$ Meanwhile, it was increasingly clear that the functions assigned to him were incompatible with the independence of the Metropolitan Police and his position as 'Secret Service Commissioner' eventually became untenable. ${ }^{290}$ By September I886, the Prime Minister considered the circumstances of Jenkinson's employment to be 'very unsatisfactory.' He had, so Harcourt informed Spencer, 'made himself impossible' and, on io December I886, the Home Secretary informed Jenkinson ('without a word of thanks') that his engagement was to be terminated. ${ }^{291}$ Nevertheless, Lord Salisbury thought that he had served the British government well 'and ought

\footnotetext{
${ }^{287}$ O'Shea to Parnell, 28 December i888: JCP, JC8/8/i/ı17. Hamilton to Spencer, 7 February I886; Spencer to Hamilton, 8 February I886: AP, Add MS 7706I.

${ }^{288}$ Porter, Origins of the Vigilant State, p. 44. Morley to Childers, I6 February I886; Godfrey Lushington to Childers, 23 February i886: TNA, HO I44/72I/ I 10757. Timothy Healy had once characterized Jenkinson as 'a species of Mokanna': FJ, I4 November i884, p. 3 .

${ }^{289}$ Jenkinson to Churchill, 9 August I886, containing confidential and very secret memoranda dated 25 July and 5 August I886: RCHL I/I4. I646, I647; Jenkinson to Buller, 27 November, 2 December I886: TNA, Buller Papers, WO I32/4A.

${ }^{290}$ Lushington, Memorandum, c.3 I May 1886; Lushington to Henry Matthews, $3^{\mathrm{I}}$ October i886: TNA, HO I44/721/II0757; Childers to Harcourt, 3 June I886: HP, Dep. Adds 18.

${ }^{291}$ Salisbury to Ashbourne, I3 September I886, repr. Cooke and Malcolmson, Ashbourne Papers, p. I65; Harcourt to Spencer, I6 December i886: AP, MS 76934. Matthews to Jenkinson, ıo December I886; Jenkinson to Matthews, I2 December ı886; Home Office minute to Treasury, I4 January I887: TNA, HO I44/72I/IIO757. Northbrook to Spencer, I2 December I886: AP, Add MS 76918.
} 
not to be cast adrift'. He regarded Jenkinson as 'a shrewd spy, with a good nose' and, in February I888, suggested that the Foreign and India Offices place him in Paris 'to try and get Russian information for us'. Nothing came of the plan, however, and Jenkinson's career in public service was over. ${ }^{292}$

Although Fottrell's career suffered less than those of Hamilton and Jenkinson, he was viewed with deep suspicion by Conservatives in Dublin, where he was regarded simply as 'the Land League lawyer'. ${ }^{293}$ His claim to have refused a place on the Royal Commission on Land in I886 because of his brother's illness should be considered against the fact that his inclusion had not been popular in Conservative circles. The Times implied that his appointment would conflict with his professional work on behalf of tenant farmers and Churchill referred to him simply as 'a snake' who had 'been warned off'. ${ }^{294}$

In spite of the removal of Hamilton and Jenkinson from Dublin, their ideas continued to influence policy makers. After the failure of home rule, both men maintained that the situation would have been much worse if the principle had not been adopted by at least one of the British political parties. As F.S.L. Lyons commented, the Bill

symbolized a mighty change in Ireland's affairs. At last a great statesman and a great party had been brought to embody Irish aspirations in legislative form. Compared with this, from which it was assumed there could be no going back, the immediate fate of the bill was of secondary importance. ${ }^{295}$

Gladstone had brought Parnell's aspirations for Ireland within the realm of practical politics. With hindsight, it seemed that the capacity of republicans and radical agrarians to disrupt the government of Ireland had been overestimated in the winter of 1885 . But if an attempt had been made to suppress Parnell's movement early in I886, then radical forces might have come to the fore in a conflict with the British authorities far more violent than that which subsequently occurred during the Plan of Campaign. Above all, Hamilton thought it was important that Gladstone's election defeat in July i886 should not be popularly regarded as "an emphatic "no" to a Home Rule policy for Ireland'. If the Irish were to believe that, then, he feared, resort would be had 'to other than constitutional means'. Testimony that this had been averted was offered to Gladstone when the militantly

\footnotetext{
${ }^{292}$ Salisbury to Cross, I2 January I887, 2 I February i888: BL, Cross Papers, Add MSS $5^{1263}$, fos ${ }^{2} 37^{-1} 38,5^{1264}$, fos 6-8.

${ }^{293}$ Buller to Ridgeway, 5 November I887: HMC, Sir Joseph West Ridgeway Papers, NRA 6957; The Times, I3 July I897, p. Io.

${ }^{294}$ The Times, I October I886, p. 7; Churchill to Ashbourne, 30 September I886, repr. Cooke and Malcolmson, Ashbourne Papers, p. Io3.

${ }^{295}$ Lyons, Parnell, p. 345 .
} 
nationalist councillors of Limerick assured him that he had placed 'the cause of Irish liberty in a position from which it cannot be driven'. ${ }^{296}$ Parnell's success in securing a place for home rule within the mainstream of British politics also convinced influential IrishAmerican republicans that persisting with constitutional politics would be the most productive path towards independence. Contrary to Jenkinson's expectations, Patrick Ford, who had pledged his support for Parnell in I884, did not alter his allegiance after the defeat of the Home Rule Bill. While the IRB remained active in Ireland, the forces of revolutionary nationalism, it seemed, were not powerful enough to divert Parnell's followers from the parliamentary course once the principle of home rule had been conceded. ${ }^{297}$

Between 1887 and I89I, Arthur Balfour dealt with the Irish nationalist movement with renewed coercion, piecemeal reforms, and an orchestrated public campaign designed to discredit Parnell and his party. While the Special Commission on 'Parnellism and Crime' failed to prove charges against Parnell himself, it inflicted mortal wounds to the home rule cause in the eyes of British public opinion, thus making the Irish party's subsequent schism over the O'Shea divorce case more damaging than it need have been. ${ }^{298}$ In Ireland, the partial suppression of the National League and the consequent reappearance of what Balfour characterized as 'retail assassination' appeared to suit Unionist purposes. Balfour informed the Cabinet that he regarded 'with unmixed satisfaction this reversion to former types of Irish discontent, which, if it be completely carried out, will entirely destroy all that was original and effective in the policy initiated by Parnell in I879'. His staff took great pains to collect evidence to demonstrate that the ultimate objective of the home rule movement was 'not union with England, but separation, and the formulation of a distinct and individual nationality'. It is ironic that some of the ammunition that Balfour gathered against the Parnellites came from the pen of Jenkinson, whose memoranda of 1885 were reprinted for the Cabinet in March r889 and used to justify policies quite different from those advocated by their author. ${ }^{299}$

\footnotetext{
${ }^{296}$ Hamilton to Spencer, I9 July I886: AP, Add MS 7706r; 'Address from the mayor, aldermen, \& burgesses of the borough of Limerick to the Right Honourable William Ewart Gladstone MP, 23 September I886': GP, Add MS ${ }_{5} 6447$, fos I4I-I43.

${ }^{297} \mathrm{MCR}(\mathrm{W})$ for October I886, Byrne, DM, 3I October 1886: CSO RP 1886/21972.

${ }^{298}$ See Margaret O'Callaghan, British High Politics and a Nationalist Ireland: criminality, land and the law under Forster and Balfour (Cork, 1994).

${ }^{299}$ Balfour, 'Confidential. Political condition of Ireland', January I889; 'Secret Societies in Ireland and the United States', 26 March 1889 : CAB 37/23/13, CAB 37/23/5 (Documents 8 and I5). See also Campbell, Fenian Fire, pp. 177-178.
} 
The political journal of George Fottrell and the correspondence generated by Edward Jenkinson and Sir Robert Hamilton demonstrate that, by I885, important figures in Irish government believed that the time had come for the Irish people to be given, as Jenkinson put it to Gladstone, 'the right to regulate their own internal affairs, the right to preserve their revenues for their own advantage, and to make their own laws'. For Hamilton, the underlying principle was that 'without sacrificing Imperial interests the country should be governed in accordance with the views of the people and not against them' ${ }^{300}$ Like Fottrell, both officials questioned the continued viability of British government in Ireland and shared the view that alternative methods had neither secured lasting peace nor politically integrated the country into the United Kingdom; as Matthew has stated, 'despite all efforts the integration was the other way, towards an Ireland largely integrated by a demand for Home Rule'. As the dangers of persisting with former methods of government became clearer, Hamilton and Jenkinson concluded that only two alternatives remained - granting self-government or repression and disenfranchisement. ${ }^{301}$

If nothing else, Hamilton and Jenkinson did much to persuade Lord Spencer to accept home rule. As John Kendle has explained, 'Gladstone would not have moved, could not have moved, without Spencer'. The task had not been easy because Spencer had been a victim of his own success. By suppressing crime and securing British institutions in Ireland during I882-I885, he had convinced many British politicians that they could continue to govern the country largely on their own terms. Support for home rule was made more difficult to secure because some leading Liberals believed that the difficulty of governing Ireland had been exaggerated..$^{302}$ Furthermore, Spencer had endured years of personal abuse from Irish nationalists, and had left the country, as Gladstone knew, 'the butt of all the sharpest arrows of Nationalism and disaffection'. Understandably, Spencer harboured strong doubts about Parnell's fitness for government and, late in I885, told Hartington, 'I get at times sick at the idea of giving up to such men!! With such a history belonging to them!!' Even after he had accepted the case for home rule, he confessed that he still found it 'odious to deal with men who have tolerated methods of agitation such as those of the Land League, and who have not when they could exerted themselves to put down outrages'. At the same time, Spencer

\footnotetext{
${ }^{300}$ See Documents 27 and $\mathbf{4 6 .}$

${ }^{301}$ Matthew, Gladstone, p. 472; Documents 27, 32, and 40.

${ }^{302}$ Kendle, Ireland and the Federal Solution, p. 43; Matthew, Gladstone, p. 45I; Jonathan Parry, The Rise and Fall of Liberal Government in Victorian Britain (New Haven, CT, I993), p. 292; Mallet, Northbrook, p. 233 .
} 
knew that there was no evidence to suggest that Parnell bore direct responsibility for crimes committed during the Land War. ${ }^{303} \mathrm{He}$ told an audience in Newcastle that, while nationalist leaders had too often remained silent 'when words would have been golden', he could say 'without doubt or hesitation' that he had 'neither heard nor seen any evidence of complicity in any of these crimes by the leaders of the Irish party'. Indeed, as Spencer drew satisfaction from the fact that it might soon be Parnell's turn to 'deal with the extremists', he admitted that this task would not be 'as tough as ours could be with the Parnellites against us' ${ }^{304}$

The viewpoint offered from Dublin Castle in 1885 was persuasive because it represented Irish self-government as an essentially conservative measure that would marginalize extremism. It was confidently asserted that Parnell's popular conservatism would provide an effective bulwark against republicanism and dominate all other strands of Irish nationalism indefinitely. Liberal politicians were encouraged to believe that home rule was not a danger but a source of strength and that the risk of separation lay in its postponement. It was, it has been argued, 'the boldest of all possible attempts to save Ireland for constitutionalism and from Fenianism' and Gladstone calculated that, for fiscal reasons alone, Parnell would adopt a 'common sense' approach to self-government and entirely reject separation from Great Britain. ${ }^{305}$

There were, however, more negative reasons for the promotion of home rule. It derived, in part, from a sense of failure and a desire to be rid of the irksome and exhausting duties of Irish government and its attendant cycle of protest, disorder, repression, and crime. During the election campaign of I885, John Morley had painted a picture of a demoralized Irish executive and it is true that Hamilton and Jenkinson were clearly dispirited by the experience of governing Ireland against its will. They were particularly disappointed to see the temporary successes achieved between 1882 and I885 appear to evaporate. Spencer was forced to accept that the Conservatives' 'surrender' to the Irish nationalists over coercion in June 1885 had made the Liberals 'see-saw policy' of repression and reform redundant. Hamilton confessed to Edward Hamilton that he had started to come round to home rule 'immediately after Lord Spencer's

\footnotetext{
${ }^{303}$ Gladstone to Spencer, 30 June I885: AP, Add MS 76862; Spencer to Hartington, 27 December 1885 , repr. $R E$, II, p. 9I. 'Draft taken from a letter to Lord Lansdowne when Mr. Gladstone's Government was formed in I886'; Spencer to Edward Hamilton, 23 September I884: AP, Add MSS 77329, 76860.

${ }^{304}$ I.S. Leadham, Parnellism and Conservatism, or the Accusers in the Dock (London, I887), p. 27; 'Draft taken ... in I886': AP, Add MS 77329.

${ }^{305}$ Matthew, Gladstone, p. 506.
} 
policy had been reversed, or (rather) allowed to fall through'. It had, he admitted 'been a fragile enough edifice to build up', one 'reared with the greatest difficulty; and it was impossible to set it up again, when once it had been pulled down' ${ }^{306}$ Personal stresses added to the sense of frustration. Jenkinson had been under particular strain for a number of years, having lived separately from his family and foregone all recreation. His experience told him that the odds were ' 8 to I in favour of the Dynamiter' and that his rare victories over the bombers did not 'go to the root of the matter'. After the explosions at the House of Commons in January I885, he had confessed to feeling as though he had 'passed through some tremendous storm, and had come out of it a complete wreck' ${ }^{307}$ A year later, Carnarvon provided Salisbury with a vivid insight into an assignment that was 'not only laborious \& difficult, but personally very dangerous'. Jenkinson was reportedly 'obliged to take his life in his hands' by meeting informants in the East End of London, work that he admitted to finding 'most uncongenial $[\ldots]$ and repulsive'. ${ }^{308}$ Clearly, his cloak-and-dagger lifestyle took its toll and a desire to be free of it is likely to have encouraged him to reassess the future of Irish government.

The accusation that Gladstone deliberately exaggerated the gravity of the Irish situation in December I885 in order to justify his remaining at the centre of the political arena seems unduly harsh when one considers the grave reports that he was then receiving from Ireland. Nevertheless, one unintended consequence of the emphasis that Jenkinson placed upon the danger posed by Irish republicanism was that it encouraged Gladstone to develop his home rule policy with damaging haste, in the belief that Ireland was on the verge of anarchy. Gladstone later defended his actions by arguing that 'once the subject was ripe, the time for action had come. We were not to wait until it was over-ripe. ${ }^{909}$ But Hamilton and Jenkinson clearly thought that bipartisanship and a process of consultation were indispensable for the success of home rule, and warned that the Liberals risked political disaster if they attempted to carry the issue on their own. It was typical of a man schooled in the ways of colonial administration that Jenkinson argued that only a gradual devolution of power would enable the Irish

\footnotetext{
${ }^{306}$ Lord Eversley, Gladstone and Ireland (London, I912), p. 285; Spencer to Lansdowne, 2 February I886, repr. RE, II, pp. I07-Iog; Edward Hamilton's diary, I3 February ı886: EHP, Add MS 48643 , fos I3-I4.

${ }^{307}$ See Document 2; Jenkinson to Spencer, I7 December 1884, 4 February I885: AP, Add MSS 77035, 77036 .

${ }^{308}$ Jenkinson to Cross, I I August I885: TNA, HO I44/72I/ I I0757; Carnarvon to Salisbury, 7 January i886: CP/TNA, PRO 3o/6/62 (53).

${ }^{309}$ Parry, Liberal Government, p. 296; Gladstone, 'The Irish Question, I886', I8 August I886: GP, Add MS 44699, fos 209-23I.
} 
to acquire the 'gradual political education' they needed to 'fit them for self-government'.$^{10}$ Nevertheless, this was an approach that was apparently shared by both John Dillon and Parnell himself: Carnarvon claimed that, during their clandestine meeting on I August I885, Parnell accepted 'the need for a "gradual growth" of self-government in order to "accustom the people" to the exercise of responsibility". ${ }^{11}$

The documents reproduced in this volume challenge the idea that late Victorian high politics was played out without serious reference to Irish events. They reveal that the condition of Ireland was a significant factor in Gladstone's decision to formulate a home rule policy during 1885-1886 and demonstrate that Dublin Castle's concern over the growing strength of Irish republicanism significantly accelerated the development of legislation. For a number of Liberal administrators and politicians, the devolution of power in Ireland was the only effective means of securing public order, political union, and strategic safety, by 'creating an empire whose cohesion came from decentralized power' ${ }^{3{ }^{12}}$ Nevertheless, as George Fottrell was to find out, opponents of home rule viewed the policy as an aspect of Fenianism rather than the means of its defeat, and many Liberals were prepared to follow Chamberlain and fight to prevent what they regarded as the dismantling of the Empire. Political opposition to home rule was grounded on English and imperial rather than Irish grounds and Hamilton was criticized for failing to take these aspects of the question seriously enough. The former chief secretary, Henry Campbell-Bannerman, reminded Spencer, 'I think, indeed, that those of us who have had to do with Ireland and know the hideous difficulties of its government are naturally disposed to take too light a view of the dangers to the Empire of the alternative to which we deem ourselves driven.' But many of the Liberals who disliked Parnell's demands still recognized that they were compatible with their own desire to balance the integration of smaller 'regional' territories into a larger nation state. The documentary evidence reproduced here suggests that the experience of governing Ireland during the turbulent years of I882-I885 convinced those most intimately involved that home rule was a natural development of the principle of popular, responsible selfgovernment, and was the only means of persuading Irish nationalists to confine their struggle for independence within the bounds of the British constitution. ${ }^{313}$

\footnotetext{
${ }^{310}$ Document 2.

${ }^{311}$ Journal (28 July 1885); O'Day, Irish Home Rule, p. 99.

${ }^{312}$ Matthew, Gladstone, pp. 468-469.

${ }^{313}$ Campbell-Bannerman to Spencer, 8 January i886, repr. Spender, Campbell-Bannerman, I, pp. 95-97; Matthew, Gladstone, pp. 437, 467 .
} 